Historic, Archive Document

Do not assume content reflects current scientific knowledge, policies, or practices. 



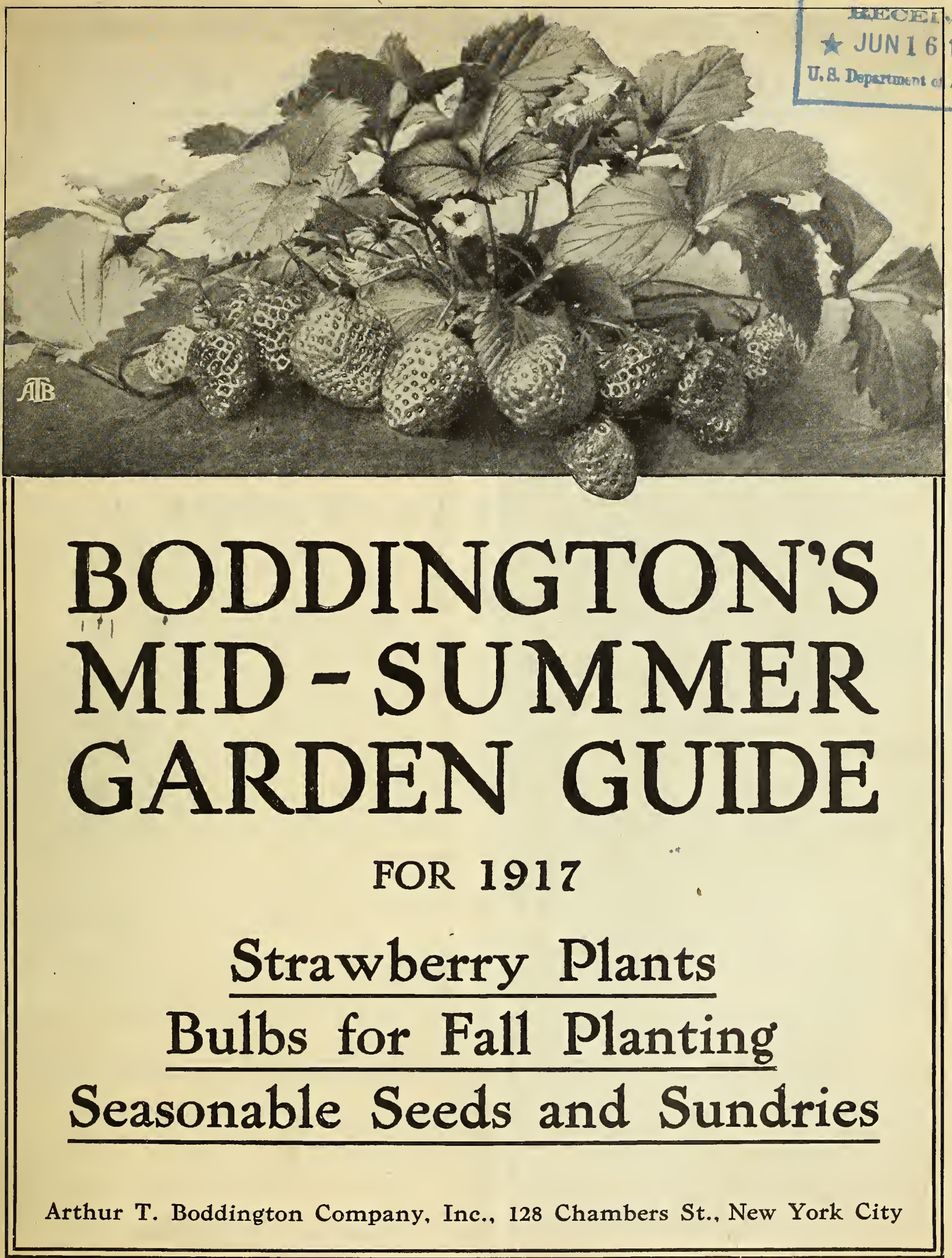




\section{POT-GROWN STRAWBERRY PLANTS}

\section{SET OUT THIS SUMMER, WILL BEAR A FULL CROP OF BERRIES NEXT SPRING}

Pot-grown Strawberry Plants are much superior to the ordinary ground layers usually sold, as there is no loss of fine roots in taking them up, consequently transplanting scarcely checks their growth; the earlier the pot-grown plants can be planted after July 20 , the larger they will grow, and the more they will produce the next spring. We do not offer a long list of varieties in Strawberries, but onlv such as may be considered the best of existing sorts.

\section{ABOUT FORWARDING, TIME TO ORDER AND WHEN READY}

Strawberry plants are sent by express only at customer's expense, orders filled in rotation. Our first crop of plants will be ready about July 20 , and if set out any time before September I 5 they. should grow into fine plants and bear a full crop of luscious fruit the next season. Culture.-Strawberries require rich, well-tilled soil, the plants should be set I 5 inches apart, in rows 2 feet apart; Ioo plants will plant 4 rows, 30 feet long. Firm the plants well in the soil, keep thoroughly cultivated and cut off all runners. In the middle of December cover the beds to a depth of 3 inches with salt-meadow hay, straw or leaves. In April, as soon as, the plants show an indication of growth, push the covering away from the plants to allow them to come up through. This mulching protects the plants from the cold in winter and the heat in summer, keeps the fruit clean, and prevents the growth of weeds.

PERFECT AND PISTILLATE STRAWBERRIES. The blossoms of Strawberries are either staminate (perfect-flowering) or are destitute of stamens and are termed pistillate (imperfect-flowering). Pistillate varieties must have a row of some perfect-flowering sort, flowering at the samc time, planted every Io or 12 feet apart among them, or, better yet, every third or fourth plant in the row, to pollenize their blossoms. When properly pollenized, the pistillate varieties are usually the most prolific. Those marked with $P$ are pistillate.

The "Everbearing" Strawberry (Americus). This variety is the finest of this class, and will continue fruiting until way into color. If you desire Strawberries out of season, this is the variety to grow. $\$ 1$ per doz., $\$ 5$ per roo.

\section{GENERAL LIST OF POT-GROWN STRAWBERRY PLANTS}

Abington. Midseason. An excellent variety. Plants are of vigorous habit, with clean healthy foliage; berries very large and attractive. Bright red in color, very solid, and of remarkably good flavor.

August Luther. Extra early. This variety is very popular not only with berry-growers, but also in the family garden; it has a host of friends, and succeeds everywhere. The berries are of good size, firm and lots of them.

Barrymore. Midseason. Perfect-flowering. A healthy, vigorous grower and very productive; large, bluntly conical berries; glossy, rich, dark crimson and of excellent flavor.

Brandywine. Midseason to late. Large, roundish, conical, glossy crimson, firm and solid; of fine aromatic flavor. Plant vigorous and productive; succeeds on any soil.

Bubach. (P.) Midseason. A very large berry of dark color. Productive; of fair flavor. Largely grown for market, where it always brings good prices.

Chesapeake. Midscason. Carries the flavor of the wild strawberry; a handsome berry and one of the best.

Commonwealth. Very late. In the Commonwealth we have a berry as large as the largest-as productive as any of the largefruiting varieties, and as fine-flavored and juicy and as darkcolored as any Strawberry grown.

Gandy. One of the very best later varieties. It is a strong, compact grower, with large, bright, glossy crimson fruit, very uniform in shape; flesh firm and of the finest flavor.

Glen Mary. Early. Large; bright, glossy crimson; of fine flavor. Plant strong and healthy, very prolific, and on good soil the berries are large to the end of the season.

Hunn. (P.) A late variety, very productive, large size, uniform shape, dark crimson, firm fiesh of the finest flavor. A strong grower and the latest sort grown.

Any of the above varieties, 60 cts. per doz., $\$ 4$ per 100, $\$ 35$ per 1,000 . Special prices given on large quantities or varieties not quoted in this list

Jessie. Early . Very productive; fruit large, light crimson in color; firm, and flavor of the best.

Marshall. Midseason. Large; dark crimson; good. Plant luxuriant, but nceds rich soil and careful culture.

New Home. As late and large as Gandy, fruit bright red, of uniformly large size. A good keeper and shipper.

New York. The berries are very large, ripening midseason. Color dark scarlet, changing to crimson when fully ripe; colors all over at once; quality first-class.

Nick Ohmer. For market, for home use or for exhibition, this is probably the greatest berry ever offered. It is a healthy, vigorous grower, and of great productiveness. The fruit is of mammoth size, beautiful in form and color, and of excellent quality.

Oom Paul. One of the largest so far introduced, and very firm for such a large berry, and will stand shipping with any of the very large varieties.

Rewastico. Color rich deep red, which penetrates the berry through and through. Very productive and a vigorous grower. Fruit of uniform large size.

Sample. (P.) Late. Fruit large, round and dark crimson in color, and of good quality.

Schofield. Early to late. Loved by everybody on account of its enormous size, bright red color, and rich aromatic flavor peculiar to itself.

Sharpless. Midseason. Demands rich, strong soil. Plant large and vigorous, berries very large, irregular in shape, crimson, moderately firm and of good quality. An old and standard variety which is still popular.

Uncle Jim. A very valuable midseason variety of large size and wonderf ul productiveness; bright red coior and finest quality,

Wm. Belt. The berries are as large as Bubach, more uniform in m. Belt. The berries are as large as Bubach,

\section{PLANTS FOR FORCING UNDER GLASS}

Royal Sovereign. In England this variety is considered the best for forcing. We do not recommend it for outdoor cultivation Re United States. $\$ 1.50$ per doz., $\$ 10$ per 100.

Pride of Redbank. Mr. William Turner, Oceanic, N. J., the famous grower of fruit and Strawberries under glass, says: "Pride of mendation that we are listing it, and offer pot-grown stock at $\$ 1.50$ per doz., $\$ 10$ per 100 .

Marshall. A most popular forcing variety. Large; dark crimson; good. Plant luxuriant, but needs rich soil and careful culture. 75 cts. Mer doz., \$5 per 100. Nick Ohmer. One of the best forcing varieties, or for exhibition. It is a healthy, vigorous grower, and of great productiveness. The
fruit is of mammoth size, beautiful in form and color, and of excellent quality. 75 cts. per doz., $\$ 5$ per 100 . 


\section{PANSIES (HP) Boddington's Giants}

Sow seed in July or August in light and well-noistened soil, improved by good fertilizer, cow-manure, or bone meal, in flats. When the seedlings are large enough to handle, transplant to permanent position, which must be light, well sheltered, and away from trees or branches. If exhibition blooms are wanted, allow only one bloom to grow on each shoot; water freely.

Recent News Item:- "A proposal is on foot to make Pansy the national flower of the United States."

Boddington's Challenge. This Challenge mixture contains all the finest Giant strains of the leading Pansy specialists in the worldBoddington's Challenge. the Giant self-colors, the Giant striped and margined, and the Giant blotched-all carefully mixed in proportion. 25 cents per half-packet, 50 cts. per packet, $\$ 2.50$ per quarter-ounce, $\$ 4.25$ per half-ounce, $\$ 8$ per ounce.

Boddington's English Exhibition Mixed. This strain of Giant Pansies, introduced three years ago, has proved very satis- Pkt. $3 / 40 z$.

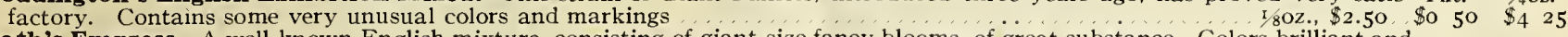

Bath's Empress. A well-known English mixture, consisting of giant-size fancy blooms, of great substance. Colors brilliant and varied. The raiser is continually reselecting the plants for seed, and each year the strain is improved.......3 pkts., $\$ 2.75 \ldots$ I oo 650

Bugnot's Exhibition. Extra-choice flow- Pkt. 1/40z. Oz. ers; large and plenty of light colors........ \$0 30 $\$ 5$ oo $\$ \mathbb{I}_{7}$ oo

Cassier's. A fine strain of large flowers........ $30 \quad 3$ so ro oo

Masterpiece (Frilled Pansies). Petals beautifully waved. Exquisite colors ........ $25 \quad 200 \quad 650$

Orchidæflora, or Orchid - flowered Pansy. Contains many beautiful shades of gorgeous colors ............................ 60 60300 10 00

Sim's Gold Medal Mixture. $w$ a s the First Prize and Gold Medal at the International Horticultural Exhibition, held at the Grand Central Palace, New York City, April, 1913, and is the result of years of painstaking cultivating and selecting on the part of Mr. William Sim (renowned for Sweet Peas).

$$
3 \text { pkts. } \$ 2,1 / 80 z, \$ 5 \cdot 75 \cdots 75
$$

Trimardeau. Mammoth flowering and in a good range of color...................

Triumph of the Giants. ture of exceed-

ingly large and beautifully marked Pansies.... $60 \quad 3 \quad 75$ I2 50

\section{Giant Pansies in Separate Colors}

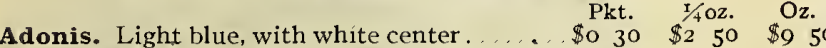

Andromeda. Rosy, with lavender tint. .... $\begin{array}{lllll}30 & 2 & 25 & 8 & 50\end{array}$

Bridesmaid. Giant flowers of rosy white,

with dark blotches in the center
Canary Bird. A five-spotted yellow variety on yellow ground.................... $30 \quad 2$ oo

Emperor Francis Joseph. Pure white, violet spots.

Emperor William. Ultramarine blue

Fire King. Red-yellow, with large brown eye

Golden Queen. Bright yellow, no eye.

Golden Yellow. Yellow, brown eye.

Hydrangea-Rose. Very distinct.

King of the Blacks. (Faust.) Black.

Lord Beaconsfield. Deep purple-violet, top petals light blue.

Mme. Perret. Many fine shades of red . . .

Mauve Queen. Delicate mauve, lower petals marked with a carmine blotch.

Peacock. Beautiful vari-colored variety

President Mckinley. Golden yellow, dark blotch

Prince Bismarck. Yellowish bronze

Pretiosa. Crimson-rose, white margin

Psyche. Violet bordered white; waved petals

Rosy-Lilac..

Ruby Iring. Superb crimson and red shades

Snowflake. Immense Pure white.

Snow Queen. White, center tinged yellow

Striped.

Vulcan. Dark red, with five black blotches.

White. Violet spot

\section{Giant Winter-Flowering Pansies}

These varieties are specially adapted for growing in coldframes or a cool house.

Winter Sun. Golden yellow, with dark eye.

Ice King. Silvery white, with dark blue eye.

Celestial King. Light and sky-blue.

Charm of March. Dark velvety blue

Mixed. Very fine shades in mixture.

Pkt. 40 cts. Collection, 1 pkt. each variety, $\$ 1.50$

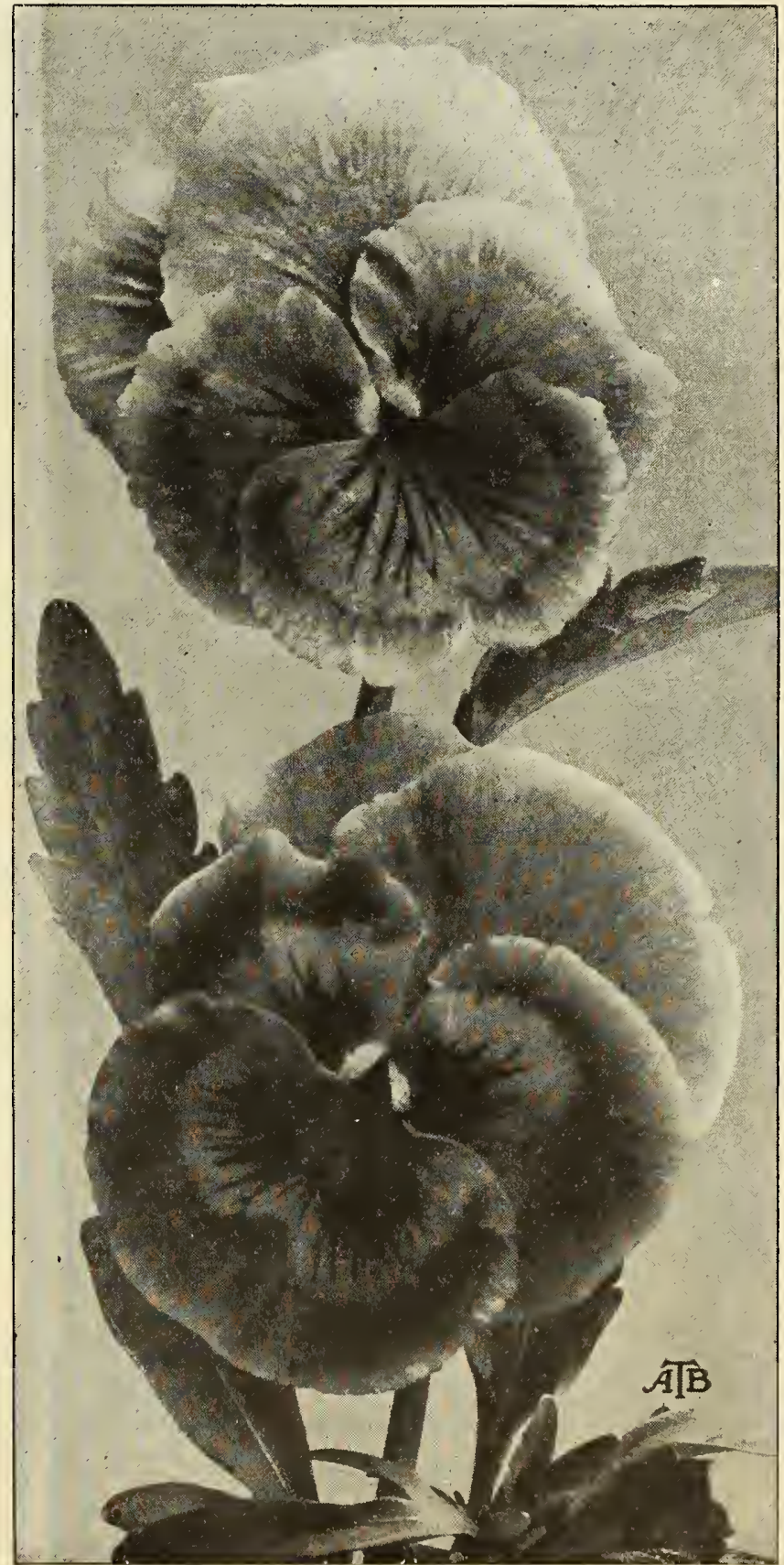

Pansies, Boddington's Challenge 


\section{WINTER-FLOWERING SPENCER SWEET PEAS}

Cultivation: White-seeded varieties must be sown in sand in small pots, not in Cultivation: earth, or they will rot or "damp off;" later, transplant to the permanent position. Winter-flowering Sweet Peas should not be sown too thickly, about one ounce to 25 feet is sufficient. Thin out to about 3 inches apart when plants are about 6 inches high; if wanted for Christmas, sow before the end of September; if wanted during January, February and March, about the middle of October; if wanted for Easter, about the first of December. For successful growing, a temperature of 40 to 45 degrees at night and Io degrees higher in the day is considered best. Watch out for red spider, thrip, and green fly. Feed when plants are in full bloom.

\section{The Sensational Australian Spencer Winter-Flowering Sweet Peas \\ CONCORD COUNTESS IMPROVED (Novelty)}

A larger and much finer strain of Concord Countess. The blooms are of magnificent size and of perfect Spencer form. The color is a clear blush-pink on white ground, deepening somewhat at the edge of the standard. Three and four blooms on a stem. Pkt. (25 seeds) $50 \mathrm{cts}$., 5 pkts. for $\$ 2.25$.

\section{CONCORD EXOUISITE (Novelty)}

Pale pink on rich cream ground; three on stem, of perfect form. A very attractive variety. Pkt. (25 seeds) 50 cts., 5 pkts. for $\$ 2.25$.

\section{CONCORD BLUSH SHADES}

Produces blooms as large and of as fine Spencer form as any other variety in this section. The colors range from almost white-blush and creamy pink to deep pink. Pkt. ( 50 seeds) $50 \mathrm{cts}$., 5 pkts. for $\$ 2.25$.

\section{CONCORD CHIEF}

Intense rich deep maroon; massive Spencer form. Pkt. (50 seeds) $50 \mathrm{cts.,} 5$ pkts. for $\$ 2.25$.

\section{CONCORD CHARM}

This da inty new Pea combines the delicate shades of white and blue-white wings and very light heliotrope standard, shading to nearly white; very captivating, of the best Spencer form and largest size. Pkt. (50 seeds) 5o cts., $5 \mathrm{pkts}$. for $\$ 2.25$.

\section{CONCORD CHRISTMAS PINK SHADES}

A Spencer strain of the old Christmas Pink coloring. Rosy cerise standard, creamy white wings, slightly tinted blush. There is at times some variation in these; so we offer as shades. Pkt. (50 seeds) $50 \mathrm{cts}$., 5 pkts. for $\$ 2.25$.

\section{CONCORD COUNTESS}

A superbly beautiful new variety of a most attractive tint of pink, the ideal flower color. The color graduates to a lighter tint at the base of standard and wings, adding additional charm to this variety. The flowers are large, of true Spencer form, and are carried mostly in threes on good long stems. Pkt. (50 seeds) $50 \mathrm{cts}$., 5 pkts. for $\$ 2.25$.

\section{CONCORD COQUETTE}

A most beautiful variety of the "veined" or mottled class. It has a white ground, faintly marked or mottled light rosy carmine, the standard showing the color rather more heavily than the wings: Spencer form, good stems carrying up to three and four good-sized blooms. This is a splendid variety, bunching beautifully. Pkt. (50 seeds) 50 cts., 5 pkts. for $\$ 2.25$.

\section{CONCORD DAYBREAK}

On opening, the bud is cream with standard heavily edged buffpink. As the flower opens the cream changes to almost white, and the cream-pink edging to a faint rosy tinge; largest size and finest Spencer form. Stems long and wiry, carrying three and sometimes four on a stem; one of the finest varieties. Pkt. (5o seeds) $50 c$. 5 pkts. for $\$ 2.25$

\section{CONCORD EMPEROR}

A rich crimson-red variety, indispensable on account of its glowing color and splendid qualities of size, form, substance, and freedom of flowering. One of the best and most useful varieties in this class. Pkt. (5o seeds) 50 cts., 5 pkts. for $\$ 2.25$.

COLLECTION: One packet each of the above 14

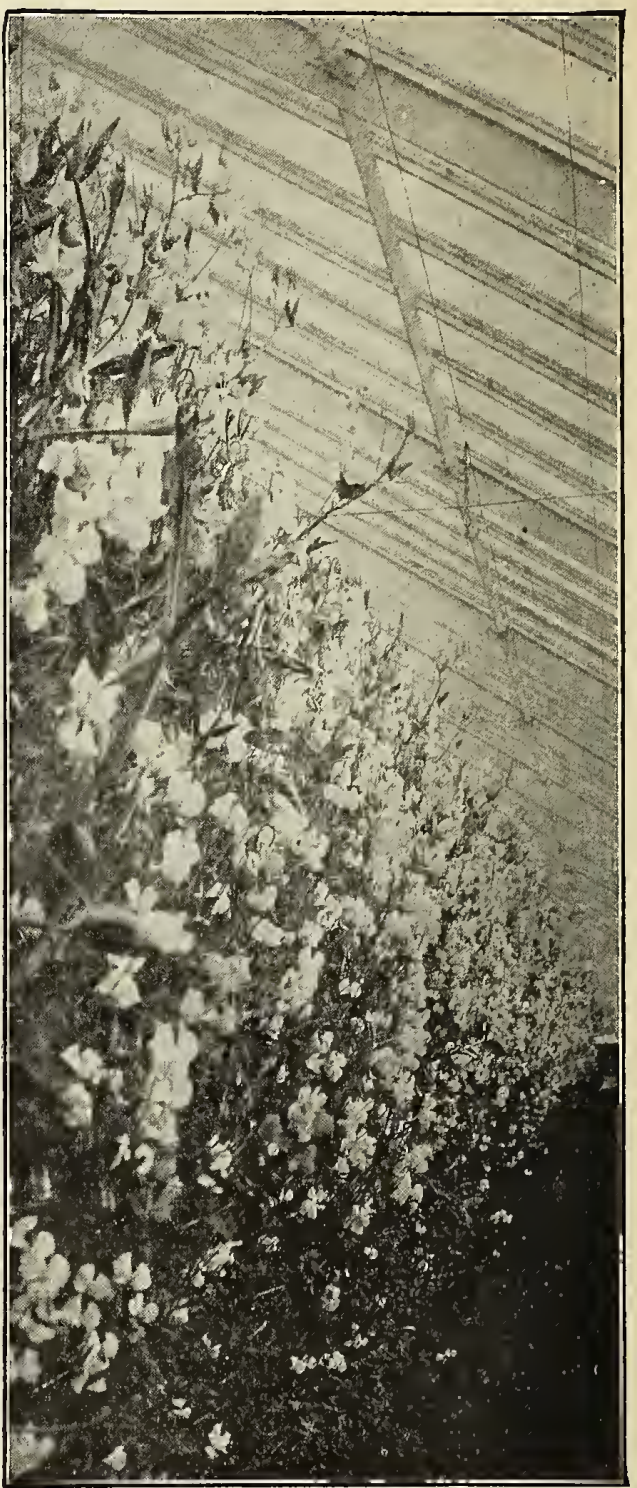

Boddington's Winter-flowering Spencers, as grown by Wm. Sim, Cliftondale, Mass.

\section{CONCORD MAUVE SHADES}

Contains a number of exceedingly fine mauve and lavender tints. Recommended. Pkt. (50 seeds) 50 cts., 5 pkts. for $\$ 2.25$.

\section{CONCORD PURPLE}

A delightful shade of mauvy purple, changing, as the flower ages, to purple-blue. The flowers are enormous, of perfect Spencer form and great substance. Pkt. (50 seeds) 50 cts., 5 pkts. for $\$ 2.25$.

\section{CONCORD RADIANCE}

A very striking shade of rosy magenta, in the highest class as regards size, form, substance, and stems. The color varies somewhat, according to the age of the flower, but this adds to its attractiveness. Pkt. (50 seeds) $50 \mathrm{cts}$., $5 \mathrm{pkts}$. for $\$ 2.25$.

\section{CONCORD WINSOME}

Of a delightful shade of pink, tinted lavender. Spencer form, long wiry stems. A specially beautiful variety. Pkt. (50 seeds) $50 \mathrm{cts.,}$ 5 pkts. for $\$ 2.25$.

"Concord" varieties for $\$ 6$. Seven varieties for $\$ 3.25$ 


\section{AUSTRALIAN SPENCER WINTER-FLOWERING SWEET PEAS, continued}

\section{BLUE FLAKED}

Rich. deep blue, lavishly penciled over a delicate gray-white ground. One of the showiest varieties. Most distinct and attractive and should be grown by all who are at all interested in Sweet Peas. One of the best. Pkt. (50 seeds) 50 cts., 5 pkts. for $\$ 2.25$.

\section{CAERULEA}

A glorious Sweet Pea of the most delightful shades: of delicate sky-blue, sometimes a little lighter. The blooms are of good open form, three on a stem. One of the most glorious tints in this collection, and in every way a most attractive variety of good substance. Pkt. (50 seeds) 50 cts., 5 pkts. for $\$ 2.25$.

\section{Yarrawa}

\section{RUBY}

A glowing ligh.t crimson-scarlet color, blooms of good size, Spencer form, carried in threes, well placed on good wiry stems. Pkt. (50 seeds) 50 cts., 5 pkts. for $\$ 2.25$.

\section{SALMONEA}

A rich rosy salmon variety of great merit. Very free flowering, it bears three and sometimes four blooms on a stem, the blooms being of good size and nicely waved form. Pkt. (50 seeds) 50 cts., 5 pkts. for $\$ 2.25$.

\section{WHITE SWAN}

White; of good size, form, and substance. Very profuse bloomer. Pkt. (50 seeds) 5o cts., 5 pkts. for $\$ 2.25$.

\section{WINTER SPENCER}

Bright rose-pink, with light wings. Yarrawa has the heavy foliage and strong growth of the summer-flowering type, and is a true winterblooming Spencer. Seed sown early in September will flower about December I, and bloom profusely and continuously until May. The flowers are exquisitely waved, and when full-grown will average $2 \mathrm{I} / 2$ inches in diameter. Pkt. 50 cts., $3 \mathrm{pkts}$. $\$ \mathrm{I} .25, \mathrm{I} / 4 \mathrm{oz}$. $\$ \mathrm{I} .5 \mathrm{O}, \mathrm{oz}$. $\$ 4.75$.

\section{American Winter-Flowering Spencer Sweet Peas}

ANITA WEHRMANN. A beautiful shade of lavender; large flowers, long stems, very prolific. Pkt. 30 cts., 4 pkts. $\$ \mathrm{I}, \mathrm{T} / 4 \mathrm{Oz} . \$ 2.25, \mathrm{oz} . \$ 8$.

APRICOT ORCHID. Mostly apricot self. A cross between Miriam Beaver and Mrs. A. A. Skach. Pkt. $50 \mathrm{cts.,} 1 / 402 . \$ 1.50,0 z . \$ 4$.

BELGIAN HERO. A beautiful rose-colored variety. Handsome flower. Useful for late sowing, following chrysanthemums. Pkt. 5o cts., $1 / 4 \mathrm{Oz}$. $\$ 2.75, \mathrm{Oz}$. $\$$ IO.

BOHEMIAN GIRL. One of the finest pink selfs. The same shape as Mrs. A. A. Skach, but the color is darker, with light scarlet blush. Pkt. $50 \mathrm{cts}$., $\pi / 4 \mathrm{oz}$. $\$ 1.50, \mathrm{Oz} . \$ 4$.

BRIDAL VEIL. Pure white. A cross between White Orchid and Watchung; one of the earliest. Its size and purity of color make it one of the best. White-seeded. Pkt. $50 \mathrm{cts}$., $1 / 4 \mathrm{Oz} . \$ \mathrm{I} .50,0 z . \$ 4$.

CHRISTMAS PINK ORCHID. This is the same color as the old Christmas Pink, standard bright pink, wings white, an improvement over the Pink and White Orchid. Pkt. 50 cts., 3 pkts. $\$ 1.25$ $1 / 4 \mathrm{Oz} . \$ 2.25, \mathrm{Oz} . \$ 7.50$.

E. BURKE. Perhaps the best of its color. The flowers are large, borne usually in fours on long strong stems; very early and fixed. We recommend this as the best lavender winter-flowering Spencer to date. Pkt. 50 cts., $1 / 4$ Oz. $\$ 3$, Oz. \$II.

FORDHOOK PINK. The color is a beautiful rose-pink on white ground shading deep pink toward the edge of the standard and wings. The flowers are of a large size, exquisitely waved and produced in threes and fours on long strong stems. Pkt. $50 \mathrm{cts}$., $1 / 4 \mathrm{Oz}$. $\$ 2$, oz. $\$ 7.50$.

FORDHOOK ROSE. A charming shade of rosy carmine. The flowers are of giant size and borne in threes and fours on very long stems. Well recommended. Pkt. 50 cts., $1 / 4 \mathrm{oz} . \$ 2, \mathrm{oz} . \$ 7.50$.

MRS. A. A. SKACH. Beautiful, clear, bright pink. Much larger than Countess Spencer and slightly darker. Pkt. 30 cts., 4 pkts. $\$ \mathrm{I}$, 1/40z. 75 cts., oz. $\$ 2.75$.

MRS. JOS. MANDA. Light shell-pink, with extra long stem, flowers very ruffled, becoming a brighter pink the longer they are cut; well fixed. Pkt. 30 cts., 4 pkts. $\$ \mathrm{I}, \mathrm{x} / 4 \mathrm{Oz} .75 \mathrm{cts}$., 0z. $\$ 2.75$.

MRS. M. SPANOUIN. Double; white. Black-seeded. Pkt. $30 \mathrm{cts}$, 4 pkts. $\$$ I, $1 / 4 \mathrm{Oz} .75$ cts., oz. $\$ 2.75$.

COLLECTION: One packet each of the above 26 varieties of American Winter-Flowering Spencers for $\$ 10.50$

MRS. JOHN M. BARIKER. The standard is lilac, with glistening dark rose, wings light blue on white ground. One of the largest and most beautifully formed. Pkt. 50 cts., 3 pkts. $\$ \mathrm{I} .25,1 / 4 \mathrm{Oz} . \$ \mathrm{I} .5 \mathrm{O}$, oz. $\$ 5$.

MISS FLORENCE ROLAND. Light pink with salmon; fine shape and good grower. Pkt. 50 cts., I/4 oz. $\$ 2.75$, oz. \$IO.

MORNING STAR. Exceptionally large flower of self pink color. Pkt. 50 cts., $\mathrm{T} / 4 \mathrm{Oz}$. $\$ 2.50$, oz. $\$ 9$.

ORANGE ORCHID. Standard orange, wings dark salmon-pink, beautifully colored and formed. Pkt. $50 \mathrm{cts}$., 3 pkts. $\$ \mathrm{I} .25,1 / 4 \mathrm{oz}$. $\$ 1.50$, oz. $\$ 5$.

ORCHID BEAUTY. Dark rose-pink, with orange blush. Pkt. 30 cts., 4 pkts. $\$ 1,1 / 4 \mathrm{Oz} .75$ cts., oz. $\$ 2.75$.

PINK-AND-WHITE ORCHID. Similar in color to Christmas Pink, but produces a larger flower on longer stems. Pkt. 30 cts., 4 pkts. $\$ 1,1 / 40 Z$. 75 cts., Oz. $\$ 2.75$.

RED ORCHID. Bright cherry-red, very fine shape, large and free bloomer. Pkt. $30 \mathrm{cts}$., 4 pkts. $\$ \mathrm{I}, 1 / 4 \mathrm{Oz}$. $75 \mathrm{cts}$., Oz. $\$ 2.75$.

ROSE QUEEN. A pink of sterling merit and of most pleasing shade. Sown indoors July 25 , first flowers picked October $I$, continued blooming until Easter. Size, length of stem, and shade could not be improved upon. Pkt. 50 cts., 3 pkts. $\$ 1.25,1 / 4 \mathrm{Oz}$. $\$$ I.5O, oz. $\$ 5$.

SELMA SWENSON. This variety is a very strong grower and an excellent forcer. The color is clear, light, soft pink with waved petals. One of the best pink varieties. Pkt. 50 cts., $1 / 4 \mathrm{Oz} . \$ 2.75$, oz. \$1o.

SENSATION SCARLET. This variety is extremely early, very productive and throws three to four flowers on stems measuring up to 16 inches in length. The color is a good bright scarlet similar to King Edward Spencer. Pkt. $50 \mathrm{cts}$., $\mathrm{\pi} / 4 \mathrm{Oz}$. \$2.75, oz. \$Io.

THE CZAR. Standard rose, wings white, mottled with pink; very strong grower. Pkt. $50 \mathrm{cts}$., $1 / 4 \mathrm{Oz} . \$ 3, \mathrm{Oz}$. \$I I.

VENUS. Standard slightly blush-pink; in winter more white. Pkt. 30 cts., 4 pkts. $\$ 1,1 / 4 \mathrm{Oz}$. 75 cts., oz. $\$ 2.75$.

WHITE ORCHID. Pure white; has stood the most critical tests. Pkt. 30 cts., 4 pkts. $\$ 1,1 / 4 \mathrm{Oz} .75$ cts., oz. $\$ 2.75$.

\section{GRANDIFLORA WINTER-FLOWERING SWEET PEAS}

PINK BEAUTY. Rose-pink. Pkt. I 5 cts., oz. 50 cts., I $/ 4 \mathrm{lb}$. $\$$ I.75. BODDINGTON'S SNOWBIRD. An exceptionally early Sweet Pea for indoor flowering. Color clear white. Pkt. Io cts., oz. 25 cts., $1 / 4$ lb. 75 cts.

BODDINGTON'S CHRISTMAS PINK. This is the earliest and most useful grandiflora Sweet Pea as, by sowing the seed under glass in latter part of August, flowers can be cut from Thanksgiving on during the winter months. Pkt. Io cts., $02.25 \mathrm{cts} ., 1 / 4 \mathrm{lb}$. 75 cts.
BODDINGTON'S CHRISTMAS WHITE. Just as free and early as Christmas Pink. Pkt. Io cts., oz. 25 cts., r/4lb. $75 \mathrm{cts}$.

LE MARQUIS. This is the same color as Princess of Wales Violet; has very large flowers. Pkt. Io cts., oz. $30 \mathrm{cts}$., I/4 lb. \$I.

MRS. ALEX. WALLACE. Lavender. Pkt. Io cts., oz. $30 \mathrm{cts.,}$ I/4lb. $\$$ I.

ZVOLANEK'S PINK. Light shell-pink, one of the well-known extralarge commercial varieties. It is as good for inside as for the open. Pkt. I 5 cts., oz. 50 cts., I $/ 4 \mathrm{lb}$. $\$$ I. 75 . 


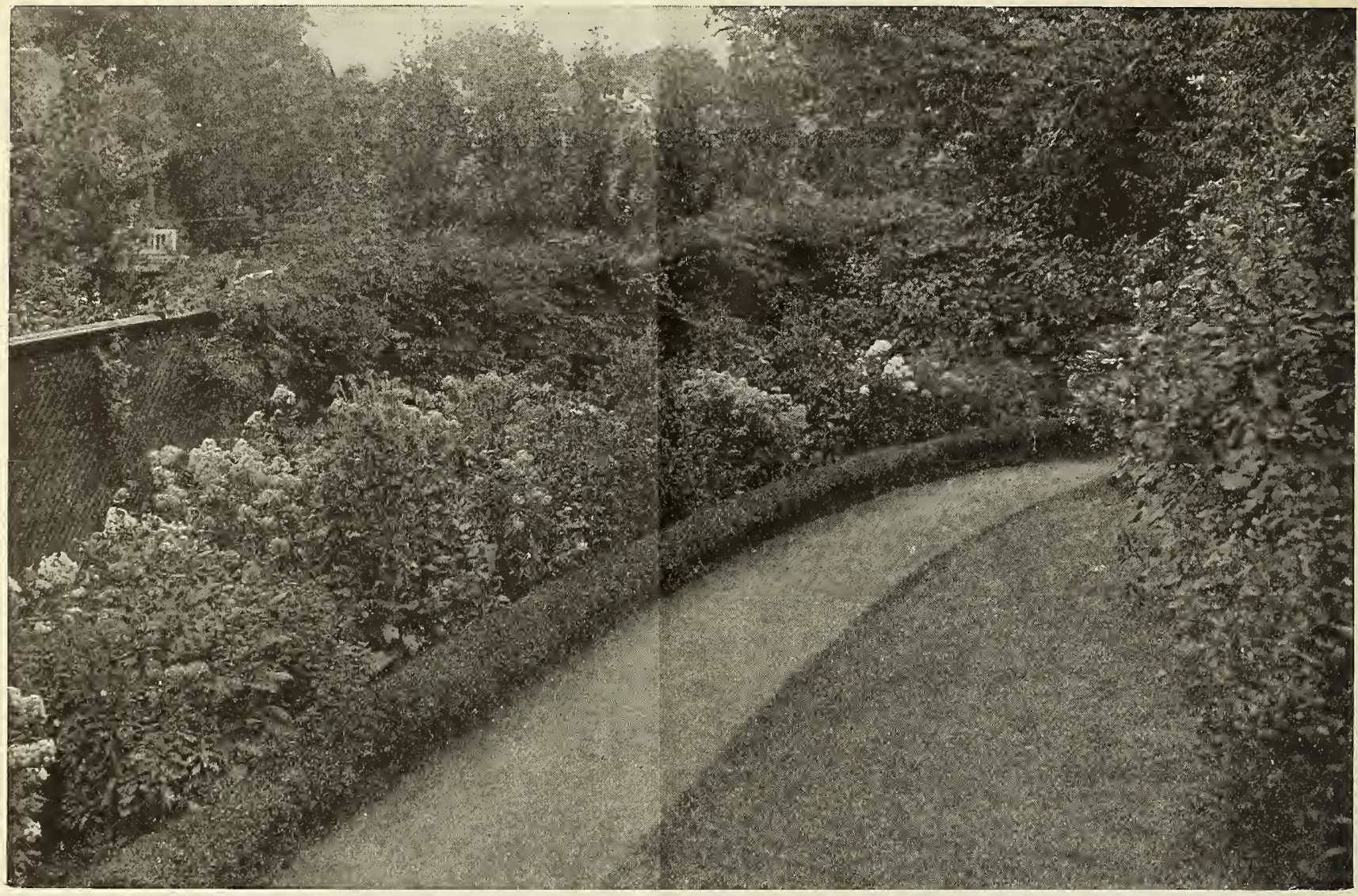

\section{Hardy Perennial and Old-Fashioned Flowers}

\section{THAT CAN BE PRODUCED FROM SEED SOWN IN SUMMER AND FALL}

Cultural Directions.-Perennial seeds sown in the summer and fall will flower the following year-spring, summer, or fall, according to the variety. The seed should be sown carefully, the same as any choice seed, in well-drained pots, or shallow boxes or pans. Soil should be light and fairly rich, with about one-eighth coarse sand added; after sowing, cover lightly with well-sifted soil. When the plants have become large enough to handle, "prick out" about 2 inches apart, more if you have the room, in shallow boxes or frames, and again, when large enough, set out in the open in well-prepared ground. If this is done in the fall, the young plants should be lightly covered with leaves or short stable manure; this will act as a slight protection, and will be conducive to their thriftiness and next season's growth.

\section{Boddington's Quality Perennial Seeds for Wild Gardens and Woodlands}

\section{SPLENDID MIXTURES OF MORE THAN ONE HUNDRED BEAUTIFUL VARIETIES}

These mixtures contain many beautiful and interesting perennials, furnishing a profusion of bloom from early summer until frost. They are intended to produce a display without the care necessary to regulariy kept flower-beds. We sell annually large quantities of these seeds for beautifying the surroundings of seashore and country hotels and residences. They not only beautify the grounds, but afford many varieties of flowers useful to cut for house decoration. Owing to the large number of varieties comprising the mixtures, one finds some new variety of bloom almost every day, and it is most interesting to watch for them.

Dwarf Wild Garden Flower Seeds. x/z-oz. 25 cts., oz. 50 cts., $x / 4$ lb. $\$ 1.75,1 b . \$ 6$, postpaid.

Tall Wild Garden Flower Seeds. $x / 2$-oz. $25 \mathrm{cts}$, , oz. $50 \mathrm{cts.}, 1 / 41 \mathrm{~b}$. $\$ \mathrm{I} .75, \mathrm{lb}$. $\$ 6$, postpaid.

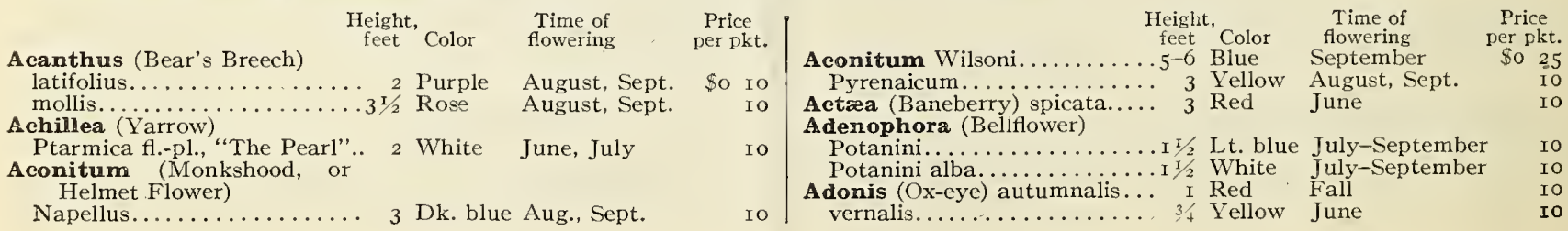


Height coronaria atropurpurea....2 $1 / 2$ Pink coronaria bicolor......... 3 Pk. \& wh. coronaria alba........... 3 White Flos-Jovis (Flower of Jove)... 3 Dk. pink Flos-Jovis alba........... 3 White

Hybrida Walkeri $\ldots . . . .2 \%$ Crimson

Alstrœmeria (Chilian Lily)

Chilensis.............. 2 Ro. wh. or.July

Alyssum argenteum ......... I Yellow June saxatile................ I/2 $B$, yellow June saxatile compactum (Basket of Gold $\ldots \ldots \ldots \ldots \ldots \ldots \ldots$

Sutton's Silver Queen......... J $1 / 2$ Lemon June

Amsonia salicifolia.......... 2 Pale blue June

Anchusa (Alkanet) Barrelieri.. 2 Dark blue July

Italica. ............. 4 -6 Pale blue July

Italica, Dropmore Variety . . . $4^{-6}$ Deep blue June, July

Anemone (Windflower)

Apennina ............ $1 / 2$ Blue Spring

Honorine Joubert......... 3 Pure white August

St. Brigid .............. I Mixed Spring

Time of Price

owering per pkt.

une, July

une, July

June, July

une, July

ne, July

\$o Io

IO

IO

I0
I0
I0

IO

10

I0

I 5

I5

50

Anthemis (Marguerite) Kelwayi................2-3 Yellow July

Aquilegia (Columbine) Boddington's Long-spurred

Hybrids. .

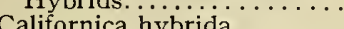

Cana

Canadensis (Canada Col.)....
chrysantha.....

chrysantha grandifiora alba...

cærulea (Rocky Mt. Col.)....

cærulea fl.-pl...............

glandulo

nivea grandiflora.

Rose Queen.

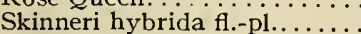

Stuarti.

Erskine Park Hybrids. . . . . . .

Sutton's Pink..............

Arabis (Rock Cress) alpina....

formosa alba. formosa.....

Artemisia (Old Man)argentea

sacrorum viridis..........

Asclepias tuberosa..........

Asperula (Sweet Woodruff)

odorata.......... . . . . .

albus.................. 3 White
luteus............. Summer

luteus.

alpinus speciosus........... I Dark blue Fall

alpinus superbus............ I Blue I

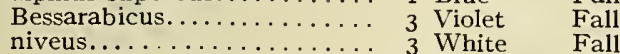

niveus....

Fall

Novæ-Angl

4 Blue, pur. Fall

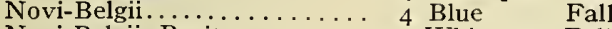

$\begin{array}{lll}\text { Novi-Belgii, Purity.......... } 4 \text { White } & \text { Fall } \\ \text { pyramidalis hybridus....... } & 4 \text { Blue }\end{array}$

Shortii............... 3 Lav.-blue Fall

Snowflake.............. 3 Pure white Fall

subcæruleus............ 4 Pale helio. Summer

Townsendii............... 2 Lilac July-October

Astilbe Davidii............ 4 Mauve Summer

Aubrietia (False Wall Cress)

deltoidea grandiflora(trailing). I/2 Purple Early summer

Græca (trailing)........... 1/2 Purple Early summer

Leichtlinii............... I/2 Rosy car. Early summer

Auricula, Alpine, Mixed..... I Various Spring

Baptisia Australis.......... 2 Blue June, July

Bocconia (Plume Poppy)

Japonica............. 4 White Summer

Boltonia (Chamomile)

asteroides............. 7 Flesh-color Fall

latisquama................ 6 Pink, lav. Fall

Callirhoe (Poppy Mallow)

involucrata........... r/2 Crim.,wh. Summer

Campanula (Bellflower)

Carpatica colestina........ I/2 Blue Summer

Carpatica alba............ S $1 / 2$ White Summer

Carpatica compacta.......... $1 / 4$ Blue Summer

Carpatica compacta alba..... $1 / 4$ White Summer

fragilis.............. I/2 Light blue June-Sept.

Cam

glomerata (Clust'd Bell
(Companula, continued

Height

glomerata (Clust'd Bellflo.)
Media (Canterbury Bell)

feet Color

Time of

Price

Double White. .

Media, Double Lavender... . .

Media, Double Blue.........

Media, Double Rose. . .

Media, Double Mixed.

Media, Single Rose.

Media, Single Blue. .

Media, Single Striped.

Media, Single Mixed.

Media, Rosy Carmine

Media. Imperialis.

calycanthema(Cup and Saucer)

calycanthema alba.

calycanthema rosea.

. canthema, Mixed.....

persicifolia grandiflora........

persicifolia grandiflora alba...

persicifolia grandiflora Mœrheimii.

pyramidalis (Chimney Bell-

flower $\ldots . \ldots \ldots \ldots \ldots \ldots$

pyramidalis alba...........

pyramidalis compacta alba.

Cassia(Wild Senna)lævigata....

$\begin{array}{ll}3 & \text { White } \\ 3 & \text { Lavender } \\ 3 & \text { Blue } \\ 3 & \text { Rose } \\ 3 & \text { All colors } \\ 3 & \text { Rose } \\ 3 & \text { Blue } \\ 3 & \text { White } \\ 3 & \text { Striped } \\ 3 & \text { All colors } \\ 3 & \text { Rose } \\ 3 & \text { Mixed }\end{array}$

2 Blue

2 Bright rose

Various

$\begin{array}{ll}3 & \text { Blue } \\ 4 & \text { White }\end{array}$

June, July

3 Dbl., white June, July

5 Blue

5 White

3 Blue

Late summer

Late summer

Late summe

Late summer

3 Yellow July, August

Marylandica..............

Catananche cærulea.......... I $1 / 2$ Pale violet Summer

Centaurea (Cornflower)

2 Red Summer

montan

2 Blue

Summer

montana alba.

Summer

orientalis. ............... $2^{1 / 2}$ Pale yel. Summer

ruthenica

Cephalaria (Roundhead)

alpina. . . . . . . . .

Cerastium tomentosum
Chelone (Turtle Head)

barbata coccinea. .

barbata Torreyi.

Lyonii.

Cheiranthus Kewensis.........

Chrysanthemum (Moonpenny maximum, Shasta.

I $1 / 2$ White Summer

maximum, King Edward VII. 2 Glist.white Summer

Clematis (Virgin's Bower)

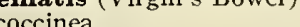

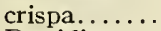

6 Scarlet

Dlamidiana.

6 Purple

5 Lilac

paniculata. .

Whit

Coreopsis grandiflora.

lanceolata.

Corydalis (Fumitory) nobilis.

Cowslip (Primula officinalis).

Cyclamen (Hardy Species)

Europæum.....

Delphinium (Larkspur)

Belladonna (true)

B's Erskine Park Hybrids.

Chinense.

Chinense album.

elatum hybridum (Bee Larkspur).

elatum coelestinum

formosum

formosum cœlestinum

Zudicaule.........

Dietamnus (Gas Plant, or Burn-

ing Bush) Fraxinella. .

Fraxinella alba.

Digitalis (Foxglove)

gloxiniæflora alba. . .

gloxiniæflora lilacina.

gloxiniæflora purpurea....

gloxinizflora rosea..........

gloxiniæflora lutea.

gloxiniæflora, mixed.

lanata..

purpurea alba.

...

purpurea rubra.

...

$\ldots \ldots \ldots$

2 Rich yel.

2 Yellow

I Yellow

I Yellow

July, August

Summer

Summer

Late summer

Winter

Summer

/4 Pure white Spring

Summer

Summer

Summer

Summer

Summer

Summer

May, June

Spring

$1 / 4$ Red-pur. Spring

5 Silvery bl. Summer

5 Mixed Sum. 5 pkts. \$I. 25

3 Light blue Midsum. Io

3 White Midsum.

5 Blue Summer

3 Light blue Midsum.

3 Dark blue Summer oz. \$I.50 Io

Sky-blue Summer

3 Sky-blue Summer

2 Y $/ 2$ Sellow Summer

25

25

2 Rosy lilac June, July

$x / 2$ White June,July

IO

3 White

Summer

3 Lilac

3 Purple

3 Yellow

3 Mixed

2 Purplish

3 White

Summer

Summer

Summer

Summer

Summer oz. 60c.

Summer

Summer

Summer

IO

IO

IO

I O

IO

20
25

IO

IO

IO

25

50

Io

25

25

IO

IO

25

IO 
HARDY PERENNIAL AND OLD-FASHIONED FLOWERS, continued

Digitalis, continued purpurea rosea... monstrosa, mixed.......... 3 Rose

maculata Iveryana..........

Dracocephalum (D ragon's Head). Altaiense........ 2 Blue

Echinacea-Helianthus

Hardy Red Sunflower........

Echinops Ritro(Globe Thistle)

Epilobium (Willow Herb)

angustifolium............ 4-5 Purple-roseSummer

Eremurus Himalaicus ....... 5 White Summer

Erigeron (Orange Daisy)

aurantiacus hybridus.

Caucasicus.

I Orange

I Violet

Early summer

speciosus............... 2 . Mau.\&yel. Early summer
Erinus alpinus...........

Eryngium (Sea Holly)

alpinum............

mamethystinum......... 3 Amethyst Summer

planum.............. I L Light blue August

Eupatorium (Thoroughwort)

ageratoides....

3-4 White

August, Sept.

Funkia (Plantain Lily)

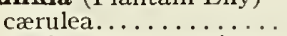

cordata aureo-variegata..

Sieboldi hybrids. .

I White

Late summer

2 Blue

2 White

$\begin{array}{ll}2 & \text { Blue } \\ 2 & \text { Mixed }\end{array}$

Summer

Summer

Summer

Gaillardia (Blanket Flower)

grandifl

grandiflora maxima.

kermesina splendens.

I $1 / 2$ Yellow

I $1 / 2$ Golden

Summer

ulphurea oculata.

I/2 Crimson

Boddington's Finest Mixed .. I I/2 All colors

Galega (Goat's Rue)officinalis . 3 Blue

officinalis alba.

3 White

officinalis rosea........... 3 Rose

Ga ura Lindheimeri. . . . . . . . . 3 I/2 Rosy

Summer

Summer

Summer

Summer oz. \$2.

Early summer

Early summer

Early summer

July-September

Geranium (Lady Perlargonium) sanguineum

2 Deep pink Early summer

Geum (Avens) coccineum...... I I/2 Scarlet

Early summer

coccineum atrosanguineum... I $\mathrm{t} / 2$ Dbl.scar. Early summer

Heldreichii.

coccineum fi.pl.. Mirs. j.

Bradshaw

Glaueium Leiocarpum......... I I 2 Or.-scarlet June-August

Gunnera scabra............ Io Or. foliage Summer

scabra major...... Gy psophila (Baby's Breath)

acutifolia............... 2 White

paniculata.................. 2 White

paniculata, Double White.... I $1 / 2$ White

repens................ I White

Harpalium (Sunflower) rigidum. 4 Yellow

Helenium (Sneezeweed)

autumnale. . . . . . . . .

Bigelowi.

Bolanderi.

Hoopesii.

Riverton Beaut

Riverton Gem.

Helianthus (Sunflower)

Perennial, Mixed.........

Pitcheriana............

Hesperis (Sweet Rocket)

matronalis, White.

matronalis, Lilac.

6 Yellow

6 Yellow

3 Yellow

$21 / 2$ Yellow

$21 / 2$ Lm.\& blk. Summer

21/4 Red \& gold Summer

July

Early sum. oz. \$I. IO

Jun.,Jul.6pkts.\$I. 20

Early summer

Late summer

Late summer

Late summer

Late summer

Late summer

Late summer

June-September Io

3 Orange

Late summer

Midsummer

Midsummer

Midsummer

Midsummer

matronalis nana candidissima. 2 White

Heuchera (Alum Root)

Brizoides..................

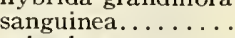

sibiscus (Marsh Mallow)

Africanus, Crimson Eye.

Golden Bowl.

moscheutos roseus.......... 5 . 3 Rose

2 Rose

2 Pink

Summer

Coral-red Midsummer

2 Deep red Midsummer

4 Wh.\&crim. Midsummer

3 Rose Midsummer

$\$ 0$ IO

IO

IO

25

IO
25

I $O$

Io

25

IO

I 5

I0
IO
IO

IO

IO

IO

IO

25

I 5

0
0
0
0

IO

Io

I0

I 5

IO

I 5

IO
Price

IO

I0
IO

IO

Io

Io

IO
I 5

IO
25

IO

Io

25

0

I

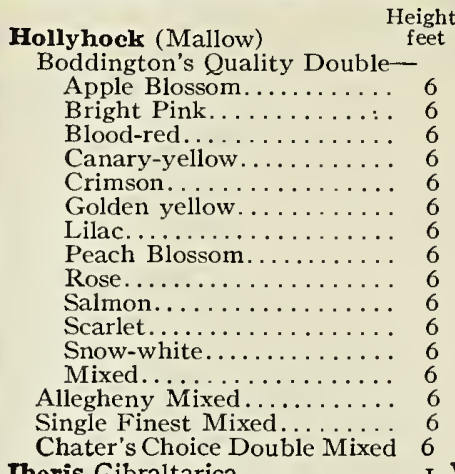

Chater's Choice Double Mixed

sempervirens............. I White

Incarvillea (Hardy Gloxinia)

Delavayi.............. 2 Rose

Inula grandiflora. . . . . . . . .

Lavand

spica................ I/2 Lavender

Lathyrus (Everlasting $\cong$ Sweet Pea)

latifolius, Pink Beauty....... Io Pink latifolius roseus............ Io Rose

latifolius albus............. Io White

Leontopodium (Alpine Sunflower, or Edelweiss)

alpinum............. 1/2 White

Liatris (Blazing Star)

scariosa præcox........... $1 / 2$ Purple

spicata. ................

Linum (Flax) perenne........

Lobelia (Cardinal Flower)

cardinalis............. 2 Fiery red

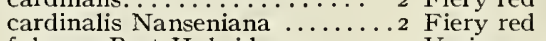

fulgens, Best Hybrids........ 2 Various

fulgens, Queen Victoria...... 2 Scarlet

Lupinus (Lupine) arboreus 4 Yellow

arboreus, Snow Queen ....... 4 White

arboreus, New Hybrids Mixed

Nootkatensis. . . . . . . . . . . .

polyphyllus roseus .......... 4 . 4 Rose-pink

polyphyllus, Mixed............

poly phyllus, New Hybrids mixed

yehnis (Campion) alpina.... 1/2 Rose

Arkwrightii............ 2 Various

Chalcedonica............ $1 / 2$ Scarlet

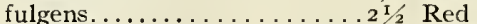

I May, June

vaageana fol. atropurpurea. I I Or.-scarlet May, June

Lysimachia (Creeping Jenny)

Japonica............

roseum superbum..........

salicaria............... $\ldots \ldots$ 3/2 Purple

Malva (Mallow) moschata.... 5 Crimson

moschata flora-alba......... 5 White

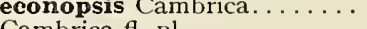

Wallachii............... $\ldots 4^{1 / 2}$ Pale blue

integrifolia.

Mimulus cardinalis............ 1 1/2 Or.\&scar

cupreus, Prince Bismarck

Monarda (Oswego Tea, or Bee Balm) didyma............

Myosotis (Forget-me-not).....

$\begin{array}{lll}\text { alpestris. . . . . . . . . . . . . . } & 1 / 2 & \text { Blue } \\ \text { alpestris, Eliza Fonrobert. . . } & 1 / 2 & \text { Sky-b }\end{array}$

alpestris, Victoria.

dissitiflora.

palustris............... .

palustris grandiflora...

semperflorens...

Royal Blue.

Enothera (Evening Primrose)

Pur.-crim.

3 Crimson

$\begin{array}{ll}1 / 2 & \text { Sky-blue } \\ 1 / 2 & \text { Sky-blue }\end{array}$

$\mathrm{r} / 2$ Blue

Spring $1 / 80 z$ Io

$1 / 2$ Deep blue Spring $1 / 80 z .50 c$. I 5

I Deep blue Spr.,Aut $1 / 80 z .40 c$. Io

I Royal blue Spring 1/80z.75c. I 5

I Blue Spring

July-September

July-September Io

July-September Io

July-September

mer

July, August

August, Sept.

July-September Io

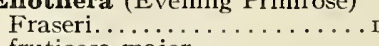

fruticosa major.

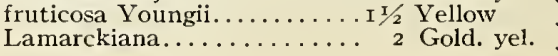

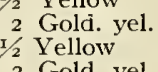

June-September

June-August

June-August

IO

25

IO 
Enothera, continued Height, cor Time of Missouriensis (maed feet Color flowering r.... I Gold. yel. Summer taraxacifolia alba............

Papaver (Poppy)

alpinum, Mixed........... I Various

bracteatum hybridum....... $2^{1 / 2}$ Red

bracteatum Livermere.......21/2 Crimson

involucratum maximum....... $1 / 2$ Red

Nudicaule (Iceland Poppy)

album............... I White Summer

coccineum................ I Scarlet Summer

croceum............. I Yellow Summer

Mixed...............

orientale, Blush Queen......

orientale, Brightness.........
orientale, Brilliant...........

orientale, Colosseum..........

orientale, Goliath.

Mix. colors Sum. oz.\$1.5o.

Pink Summer

3 Scarlet Summer

3 Crimson Summer

4 Scarlet Summer

Crimson

3 Crimson

4 Scarlet

3 Scarlet

3 Orange

3 Scarlet

3 Salmon

3 Salmon

Midsummer

Midsummer

Summer

Midsummer

Midsummer

Midsummer

Midsummer

Midsummer

orientale, Trilby

3 Mixed Ju.Au.3pkts.\$I.25 50

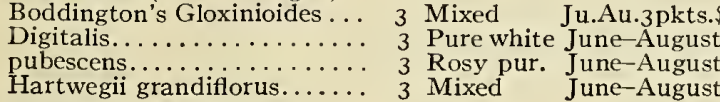

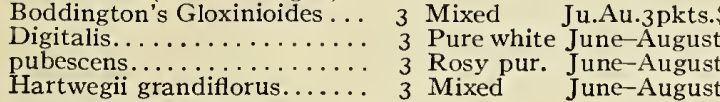

Hartwegii grandiflorus.......... 3 Mixed June-August
hlox (Flame-Flower)

decussata, newest hybrids.... 3 Mixed June-August

Physalis (Chinese Lantern Plant)

Franchetti.............. ${ }_{2}$ Or.-scarlet Fall

Physostegia (False Dragon Head)

speciosa................ Midsummer

speciosa alba..............

Midsummer

-Price

per pkt.

IO
IO

ink (Clove Carnation)

Mrs. Sinkins.............. I White Summer

Homer................ I Scarlet Summer

Platycodon (Chinese Bellfower). (See also Wahlenbergia.)

Mariesii................ I Blue June-October

Mariesii album........... I White June-October

Polemonium (Jacob's Ladder)

cæruleum album.............
cæruleum grandiflorum.....

Polyanthus (Primula elatior)

Blue.................... ro in.

English (selected strain) .... . Io in. Mixed

Gold-laced, extra choice ... Io in. Mixed

Giant White.............. I

Giant Yellow............ I

Giant Mixed...............

Polyanthus-Primrose (Bunchflowered).Large-fl'd., Mixed.

Munstead Giant Strain.......

Primrose, Large-flowered...... .

Primula cortusoides amœna

(Sieboldi) .............. ro in. Various

denticulata...............

denticulata alba.............

denticulata Cashmeriana..... I Deep vio.

frondosa............. I/2 Lilac-pur.

Japonica.................... Wo in. White
officinalis (Cowslip).... I Yellow

rosea................. Io in. Rose

$\begin{array}{rll}\text { Pyrethrum toseum............... } & 2 & \text { Rose } \\ \text { Boddington's Hybrids, Single. } & 2 & \text { Mixed }\end{array}$

Boddington's Hybrids, D'ble. 2 Mixed

uliginosum............. 3 White

Comet-flowered............. 2 2 Mixed

June-July

Spring

Spring $1 / 40 z$ I5

Spring 25

Spring

Spring

Spring

Spring

Spring

Summer

Spring

Spring

Summer

Spring

Spring

Spring

Spring

Spring

Spring

Spring

Spring

Spring

Spring

Midsummer

July 6 pkts. \$I. 20

Rudbeckia (Coneflower)......

bicolor superba.......... 2 Or.-yellow July-September

laciniata............. July-S Yellow Julember

Neumannii............. 5 Or.-yellow July-September

purpurea hybrida.......... 5 Purple July-September

Salvia argentea........... 3 White

Saponaria (Soapwort)

ocymoides............ r/4 Rose

Saxifraga (cordifolia)

Megasea, large-flowering..., : I Pink

June-August

Midsummer

Spring

Scabiosa Caucasica (Hardy feet Color

Blue Scabious).......... 2 Lavender

Time of

.

Japonica.............. 2 Lilac

Senecio clivorum $\ldots \ldots$....
Silphium (Rosin Weed)

perfoliatum

Statice (Sea Lavender)

incana hybrida nana......4 in. Violet

latifolia................... 2 Blue

Sinensis.......

Gmelini......... (Hardy Blue
tokesia cyanea

Aster) .............. 2 Blue July-October

2 Blue

June-September Io

Summer $\quad 25$

July-September Io

Fall

IO

June-September Io June-September Io

Io

Boddington's Auricula-eyed. . I 1/2 Mixed

Dark crimson. .

Newport Pink.

Pure White........

Red.

Scarlet.............

Violet.

Finest Mixed Single.

Boddington's Giant Double Finest Mixed.

Double Rose..................

Giant white $\ldots \ldots \ldots \ldots \ldots$ I I/2

Pink Beauty.............

Scarlet Beauty............ I $1 / 2$ Scarlet

Sutton's Scarlet............ I $1 / 2$

Thalictrum (Meadow Rue)

adiantifolium ............. I/ 3 Pellow

aquilegifolium.

$1 / 2$ Yellow

June-September

June-September Io

June-September Io

June-September I5

June-September Io

June-September Io

June-September Io

June-September Io

June-September Io

Dipterocarpum.

$\underset{\text { Tradescantia (Spiderwort) }}{\text { Dipterocarpum }}$

Jun.-Sep.oz.\$I.50 Io June-September I 5 June-September 20

June-September 25

June-September I 5

June-September 60

Summer

Summer

Summer

Summer

Fina (Red-Hot Poker; Flame

Trollius (Globe Flower)

Caucasicus (Golden Globe)... 2 Yellow Summer

$\begin{array}{lll}\text { Japonicus fl.-pl............ } & 2 \text { Dbl. yel. } & \begin{array}{l}\text { Summer } \\ \text { New Hybrids............ }\end{array} \\ \text { Summer }\end{array}$

Tunica (Coat Flower)

saxifraga............. r/2 Pale pur. Summer

Valeriana (Spurred Fiower)

coccinea............... 2 Scarle

montana.............. 2 Pink

rubra................. 2 Red

rubra flora alba............ 2 White

June-October

June-October

June-October

June-October

Io

50

IO

erbascum (Mullein)

Blattaria alba........... 4 White

Libani .....................

Phoniceum.

July-September

July-September

July-September

May, June

July, August

Veronica (Ironweed) candida... 2 White

incana.....

I Blue

July, August

Viola cornuta (Tifted Pansies)

Perfection.

White Perfection.

lutea.

lutea splendens.

Purple Queen.

Mixed.

odorata (Sweet Violet).

hybrida (Bedding Pansies)

Ardwell Gem

Bullion.

John Querton.

Marchioness

Mars . .

Rover.

Mixed

Wahlenbergia (Japanese Bell-

Flower) grandiflora.

grandiflora alba.

grandiflora alba-plena.

grandiflora crerulea plena.....

grandiftora cærulea

grandiflora nana...........

Wallflower (Half-hardy)

Single Fine Mixed.......... I I/2 Mixed

$1 / 2$ Blue

$1 / 2$ White

$1 / 2$ Yellow

$1 / 2$ Purple

$1 / 2$ Mixed

$1 / 2$ Blue

1/2 Primrose Spring

$1 / 2$ Golden yel. Spring

$1 / 2$ D. lavender Spring

$1 / 2$ Pure white Spring

I/2 Wte.,small Spring yellow eye

$1 / 2$ Lavender, Spring flaked wte.

I/2 Mixed Spring

IO

IO

Spring

Spring IO

I/80z.7.5c. Io 


\section{SEEDS and BULBS; Free Delivery Terms}

We deliver all Seeds and Bulbs free anywhere in the states east of the Mississippi River at prices named in this catalogue, if your purchase amounts to One Dollar or over, and cash accompanies the order, by parcel post, express, or freight, at our option, to your town or city. On Miscellaneous Garden Supplies, Implements, Fertilizers, Insecticides, Potatoes, Grass Seeds, Plants, Spirea, and Lily-of-the-Valley clumps, we do not pay postage, express, or freight charges.

As the subject of increased duties is still before Congress at the time of going to press, we have been obliged, in this catalogue, to estimate cost of all imported goods on the basis of the tariff in force last season. Please note, therefore, that prices are subject to change without notice.

\section{Retarded Lily Bulbs from Cold Storage}

Cultural Directions.-Cold-storage Lily bulbs should be potted immediately after they are received from cold storage, well watered and the pots "plunged" in the coolest place available, preferably in a cellar or the north side of a building. This is to induce as much root action as possible before growth starts. After growth starts, many aërial roots form along the lower part of the stem, immediately above the bulb. It is, therefore, well to plant the bulb low in the pot. Fill the pot with earth only three-quarters full. After the growth is Io to I2 inches high, fill the pot with good compost to within I inch of the top. This will furnish nutriment to the aërial roots, which must chiefly sustain the plants.

\section{PLANTING TABLE FOR LILIUM LONGIFLORUM GIGANTEUM}

\section{Lilium auratum and $L$. speciosum require one month longer to flower}

Meadow Saffron). The rosy lilac blossoms appear from September to November......
Autumnale album. A white variety of above.

Autumnale roseum plenum. Double; rose Parkinsonii. Peculiar checkered markings on violet-purple flowers. Petals reflexed. Flowers in October

Montanum. Mixed varieties. The beautiful winter-flowering Crocus from Turkestan... 2 2 50 I6 oo Speciosum. Beautiful rose; large flowers.... I $25900 \quad 8500$ $60 \quad 475 \quad 4500$ $\begin{array}{lllll}60 & 4 & 75 & 45 & 00 \\ 80 & 6 & 00 & 50 & 00\end{array}$ $25 \quad 900 \quad 8500$ Species of Crocus autumnale

For the winter garden these are invaluable. Robinson says: "Grocuses flower at a time when every flower is of value, and we do not doubt that ere long species recently introduced will add largely to our means of garden decoration during the dull months." Cincellatus. From Asia Minor. Flowers with white and soft pink and lilac petals, anthers Doz.
yellow. A ppears in January.............
SPECIES OF CROCUS AUTUMNALE, continued

Hyemalis. White, the outer petals lilac- Doz. I00 banded; throat orange-colored. Flowers appearing from December to April........\$I oo $\$ 6$ oo

Imperati. Often seen in January but will continue up to March. Color lilac, the surface of the outer segment is coated with rich buff, suffused with purple feathering............ Iridiflorus. From Banat and Transylvania.
Bears in September and October bright purple flowers before the leaves..........

Medius. A beautiful purple flower from the Maritime Alps. Flowers in October. Stigma bright scarlet and much branched...

Sativus. Beautiful light blue, long, narrow flowers in clusters of three. Flowers in October and Novem ber.

Speciosus. Flowers at the end of September and early in October. The peculiar segments are rich bluish purple, suffused with darker purple veins..

Zonatus. From the mountains of Cilicia. Bright vinous lilac flowers, golden at the base; a bout the middle of September.......

Vitellinus. Orange-yellow flowers, appearing from December to February............

$\begin{array}{llllll}75 & 5 & 00 & 42 & 00 \\ 00 & 6 & 50 & 60 & 00 \\ 00 & 7 & 00 & 65 & 00 \\ 25 & \text { I } & 50 & 13 & 00 \\ 25 & \text { I } & 50 & \text { I } 2 & 00 \\ 25 & \text { I } & 50 & \text { I } 2 & 00 \\ 30 & \text { I } & 75 & 16 & 00\end{array}$

I,000 $\$ 4600$

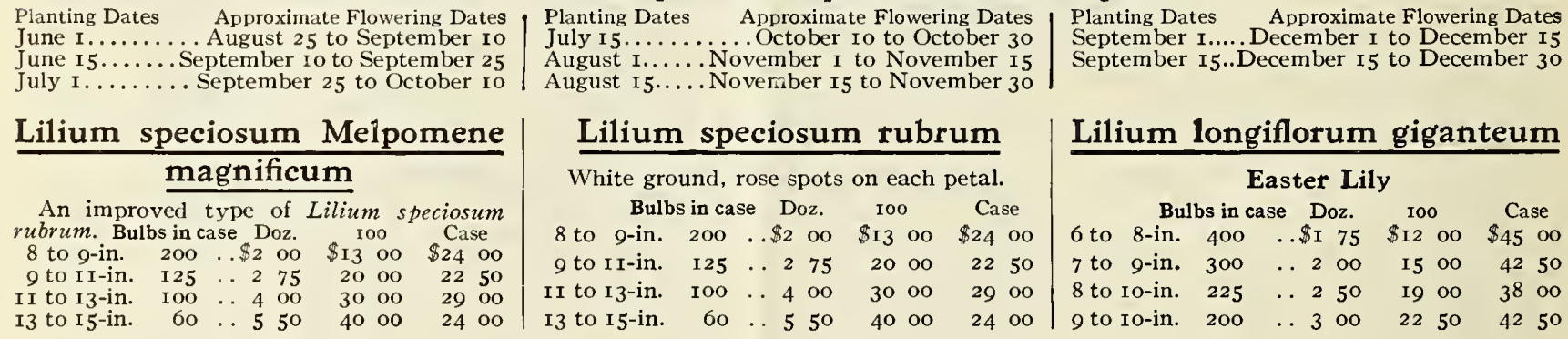

\section{Autumn and Winter-Blooming Crocuses}

Exceedingly beautiful Crocus-like flowers flowering from September to November. These are worthy of a place in every garden. Bulbs are ready for delivery in August and must be planted immediately.

Hardy Crocuses will bloom outdoors in the North between November and March with no protection whatever. Most of them are from the Holy Land, and all should be planted as early as possible in the autumn. The dates given below are the earliest they have been known to flower, but even if they do not bloom until March they are well worth while, for they will usually be seen in bloom amid the snow. The bulbs should be extensively planted, and the risk of losing them can be greatly lessened by planting in the sunniest and most sheltered nooks.

We heartily recommend their use by the thousands on southern estates, especially winter homes in the Carolinas and Georgia, where they will glorify the otherwise barren month of January. We believe, also, that they will succeed even in Canada, though blooming at the end of winter. The time of bloom depends chiefly upon the openness of the winter. Winter flowers are certainly exciting, because of the uncertainty about the time of bloom, and what can be more interesting than to find flowers outdoors in bloom in your home grounds right in the middle of winter! Several of these varieties are the very latest introductions.

\section{Species of Colchicum}

Agrippinum. Rose-purple and white......\$ Doz. $100 \quad$ I,000 Autumnale rosea major (commonly called 


\section{BULBS FOR EARLIEST PLANTING \\ and for Greenhouse and Sunny Window Forcing Next Winter (August Delivery) BUNCH-FLOWERED or POLYANTHUS NARCISSI}

CULTURAL DIRECTIONS.-Plant bulbs in shallow pans or boxes, about 2 inches apart, and store in cellar or shed till thoroughly rooted. Do not allow frost to reach them. If wanted for Christmas, bring into the light about the second week in November, and after that as many as required each week, and you will have Narcissi in bloom till Easter. They are among the most satisfactory of flowers for winter adornment of the home. General cultivation of Narcissi under glass is the same as for hyacinths, see page I 7.

Paper-White and Grand Soleil d'Or Narcissi can also be grown in water with pebbles in shallow dishes and bowls, the same as the Chinese Sacred Narcissus, or in our prepared fiber. For other varieties of Polyanthus Narcissi, see page I 8.

NARCISSUS, PAPER-WHITE GRANDIFLORA.

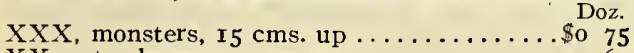
$\mathrm{XX}$, extra large, $14 \mathrm{cms}$. up $\ldots \ldots \ldots \ldots \ldots \ldots \ldots \ldots \ldots \ldots$

$\mathrm{X}$, first size, $\mathrm{I}_{3}$ to $\mathrm{I}_{5} \mathrm{cms} \ldots \ldots \ldots \ldots \ldots \ldots \ldots \ldots \ldots$

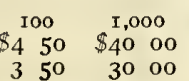

$350 \quad 3000$
NARCISSUS, GRAND SOLEIL D'OR. The "Yellow Paper-White." French-grown. Earlier than Guernsey-grown Doz. I00 I,000 French-grown. Earlier than Guernsey-grown.\$0 90 $\$ 6$ oo $\$ 5000$ Guernsey-grown. Not so early, but can be

flowered for Christmas; superior as to color .

$75 \quad 500 \quad 4000$

\section{Single Trumpet Narcissi for Christmas and January Flowering}

Silver Spur. Resembles Empress. Yellow trumpet, white perianth, but flowers are more erect and borne on Each longer stems. Its chief advantage, however, is its earliness, flowering at the same time as Guernsey

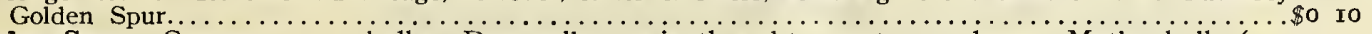

Golden Spur. Guernsey-grown bulbs. Deep yellow perianth and trumpet; very large. Mother bulbs (I or

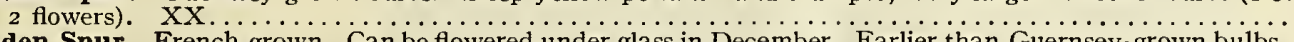

Golden Spur. French-grown. Can be flowered under glass in December. Earlier than Guernsey-grown bulbs.
French Trumpet Major. These bulbs arrive at the same time as the Roman hyacinths and Paper-White Narcissi, and, if treated in the same manner, can be flowered for Christmas

\section{FREESIAS}

If planted early, they may be had in bloom by Christmas. Plant eight to ten bulbs in a 6-inch pan, covering them I inch.

EXCELSIOR. A greatly improved form of Doz. Ioo 1,000 Refracta alba. Flowers twice as large....\$0 $80 \quad \$ 6$ oo $\$ 50$ oo

FISCHER'S SPLENDENS, Blue-Laven-

der................... 450 30 00

FISCHER'S SPLENDENS, Mauve-Lav-

ender..................... 450 30 oo

BODDINGTON'S RAINBOW. A new

race of colored Freesias which have created a sensation wherever shown. A mixture of various shades of lavender, orange,

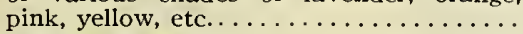

FISCHER'S PURITY. Th flowers, which are snowy white, of large size, are borne in great profusion on stems 2 to $21 / 2$ feet, which grow upright and stiff; are excellent for cut-flower purposes.

First size.....................

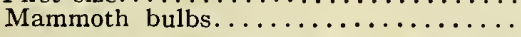

LEICHTLINII. Primrose-yellow, with

orange blotch on each petal............

REFRACTA ALBA. $X X X, 7 / 8$ to $I$ in. diam.

REFRACTA ALBA. $X X, 3 / 4$ to $7 / 8$ in. diam.

REFRACTA ALBA. $X, x / 2$ to $3 / 4$ in. diam...

$\begin{array}{lllll}75 & 5 & 00 & 45 & 00 \\ & & & & \\ 35 & 2 & 50 & 20 & 00 \\ 60 & 3 & 30 & 30 & 00 \\ 35 & 2 & 50 & 20 & 00 \\ 35 & 2 & 25 & 20 & 00 \\ 25 & \text { I } & 75 & \text { I5 } & 00 \\ 20 & \text { I } & 25 & 10 & 00\end{array}$

\section{FRENCH ROMAN HYACINTHS}

The flowers are smaller than those of the Dutch Hyacinths, but they are more gracefully set on the stems and bear a greater abundance of flower-spikes. They are far more useful for cut-flower purposes, and can be forced for a continuance of bloom from November to Easter. Cultural directions same as for Paper-White Narcissi.

White. I0 I0 I, 000 $\begin{array}{llllll}\$ 1 & \text { IO } & \$ 8 & 00 & \$ 75 & 00\end{array}$ White. I3 to I5 centimeters circumference.. I $25 \quad 8 \quad 50 \quad 80$ oo White. I4 centimeters and over........... I 5 50 Io Light Pink. I 2 to I 5 centimeters circum.... $80 \quad 6$ oo $\quad 8500$ Deep Pink. I 2 to I 5 centimeters circum.... . $80 \quad 600 \quad 5500$ Light Blue. I 2 to i 5 centimeters circum.... $80 \quad 6$ oo 5500 Yellow. I 2 to I 5 centimeters circumference. I $25 \quad 8 \quad 50$ 80 oo

\section{JAPANESE EASTER LILY Lilium longiflorum formosum}

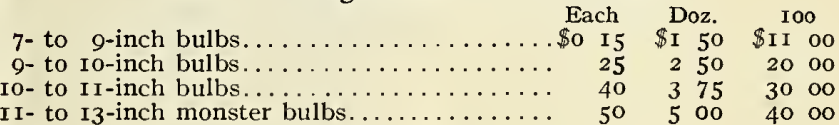

II- to I3-inch monster bulbs.

\section{BERMUDA EASTER LILY}

\section{Lilium Harrisii. August Delivery}

7- to 9-inch bulbs. .
9 - to I I-inch bulbs. Each Doz.

9- to I I-inch bulbs... $\$ 0 \quad 20 \$ 200$ $\begin{array}{rrrrr}20 & \$ 2 & 00 & \$ 15 & 00 \\ 45 & 4 & 50 & 35 & 00 \\ 80 & 8 & 00 & 65 & 00\end{array}$

\section{NERINE (Amaryllidaceæ)}

These popular South African bulbous plants are among the most charming and most useful of all early winter-flowering plants. The length of stem, the vivid and luminous colors, intensified as they are by artificial light, make this comparatively little known plant a most desirabie cut-flower for dinner-table decoration. Its use and value for this purpose is well understood in Newport and Lenox. Same cultural directions as amaryllis. The flowers are produced September and October.

Coruscans major. Scarlet..

Fothergilli major. Vivid scarlet.

Each Doz. $\quad 100$

$\$ 065 \quad \$ 6 \quad 50 \quad \$ 50$ o0

ALL THE ABOVE BULBS, EXCEPT NARCISSUS, TRUMPET MAJOR, SILVER SPUR AND GOLDEN SPUR, ARE TENDER, AND MUST NOT BE SUBJECTED TO FROST

\section{$\underset{\text { Deptember }}{\text { Delivery }}$ LILUM CANDDIDUM}

This is the old-fashioned garden Lily. Can be forced for Easter and is perfectly hardy, blooming in the open ground in June. The many snow-white flowers, borne on a stem 3 to 4 feet high, make this Lily most effective. This variety should be planted in the early fall, as it makes an autumn growth. Bulbs grown for us near Paris, France; the large-flowering, thick-petaled variety. 20 cts. each, $\$ 1.75$ per doz., $\$ 12$ per 100 . Monster bulbs, 25 ets. each, $\$ 2.50$ per doz., $\$ 16$ per 100 . 


\section{BODDINGTON'S "QUALITY" DARWIN TULIPS}

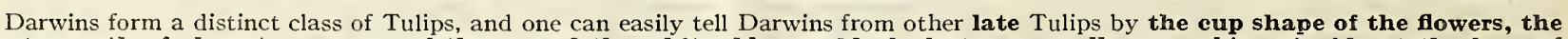

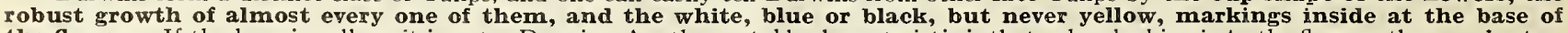

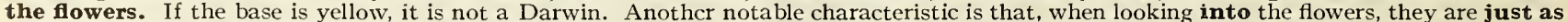

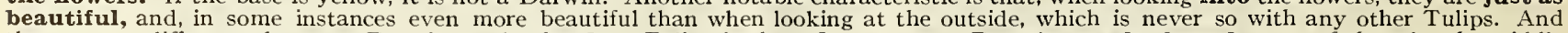

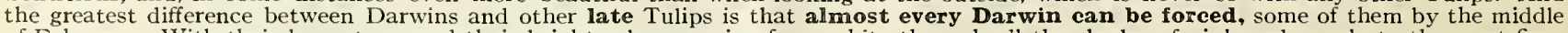

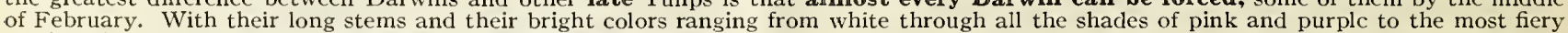
scarlet, they form an exquisite material for garden decoration.

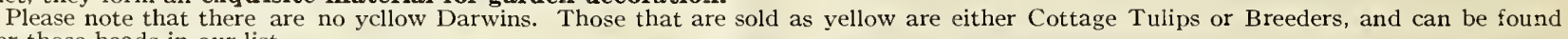
under those heads in our list.

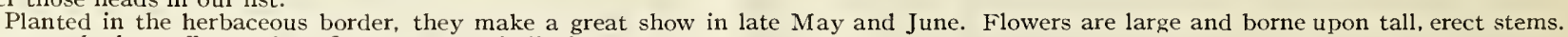
secure the best effects, plant five to twenty bulbs in a group.

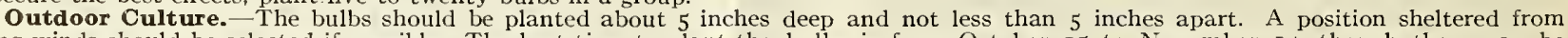

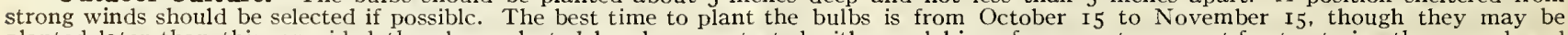

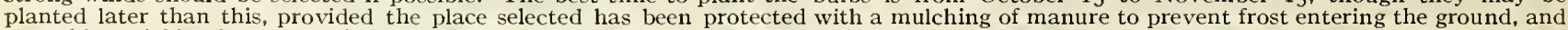

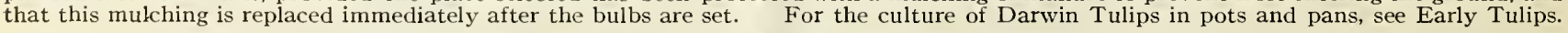

\section{Those marked with a star (*) are especially recommended for forcing}

ANTON ROOZEN. Large-flowering; rosy pink. Height 26 in. 45 cts. per doz., $\$ 2.75$ per I00, $\$ 25$ per I, 000 .

*BARONNE DE LA TONNAYE. Clear, rosy carmine; flowers are large, well formed, and keep their brightness to the last. The stems are very tall and strong. One of the best bedding Darwins. Height 26 in. $35 \mathrm{cts}$. per doz., \$2.25 per I o0, \$2 I per I, 000.

* Bartigon. Fiery red. Excellent forcer. Height 26 in. 55 cts. per doz., $\$ 3.75$ per I oo, $\$ 35$ per I, 000 .

Bleu Aimable. Bright violet-purple, shaded steel-blue; inside dark violet-purple with a blue base; very large. Height 26 in. \$2 per doz., \$I 4 per I00.

Bleu Celeste. Light blue, very distinct. Height $30 \mathrm{in}$. $\$ 2.5^{\circ}$ per doz., \$I 8 per Ioo.

City of Haarlem. The largest of the scarlet Darwins. Brilliant scarlet, with pure white center. Height 32 in. $\$ 3.50$ per doz., $\$ 25$ per Ioo.

CLARA BUTT. Beautiful, soft rosy pink. Height 24 in. 40 cts. per doz., \$2.50 per I $00, \$ 24$ per I, 000 .

Dal Ongaro. Pale lavender-violet; large flower. Height 24 in. \$I.5o per doz., \$9 per Ioo.

DREAM. Soft lilac. Height 27 in. 55 cts. per doz., \$3.75 per Ioo,

Electra. Soft lilac; a splendid variety. Height 28 in. 60 cts. pcr doz., $\$ 4.25$ per I oo, \$40 per I, 000.

ERGUSTE. Soft violet, with a slight silvery flush; white base; inside, dark violet. Hcight 26 in. 75 cts. per doz., \$5.50 per I oo, $\$ 50$ per $I$, ooo.

EUTERPE. Brilliant clear lilac. Height 26 in. \$I per doz., \$7

Europe. Fiery salmon-scarlet, white center. Height 22 in. $50 \mathrm{cts}$. per doz.. \$3.25 per I $00, \$ 30$ per I, 000 .

FARNCOMBE SANDERS. Fiery scarlet; large. Height 25 in. $60 \mathrm{cts}$. per doz., \$4 per Ioo, $\$ 35$ per I, ooo.

Faust. Dark violet, almost black; unique. Height 30 in. $\$ \mathbf{I} .30$ per doz., \$Io per IOo, \$9o per I, 00o.

Feu Brillant. Brilliant clear scarlet; large. \$I.25 per doz., \$8 per I00, $\$ 75$ per I, 000.

Fra Angelico. Deep glossy maroon. One of the finest of this color. Height 26 in. $75 \mathrm{cts}$. per doz., \$5 per Ioo.

GLOW. Brilliant glowing vermilion, center blue, margined white. Height 23 in. $55 \mathrm{cts}$. per doz., $\$ 3.50$ per I $00, \$ 30$ per I, 000 .

Isis. Glowing vermilion; one of the brightest-colored Darwins; very fine. Height 26 in. 60 cts. per doz., $\$ 4.25$ per I $00, \$ 40$ per I, 000 .

*King Harold. Purple-red; unique. Height 24 in. 45 cts. per doz., $\$ 2.75$ per IO0, $\$ 25$ per I, Ooo.

LA TRISTESSE. Dull slaty blue, with a white base. Height 26 in. $80 \mathrm{cts}$, per doz., $\$ 6$ per I $00, \$ 55$ per $\mathrm{I}$, 000 .

LA FIANCEE. Lilac-rose, fading to light rose at the edge; very large and handsome. Height 26 in. \$3 per doz., \$20 per Ioo.

LOVEZINESS. Soft rosy carmine, exquisite color. Height $2 \mathrm{I}$ in. 45 cts. per doz., \$2.75 per $100, \$ 25$ per I, ooo.

MME. JULIE VINOT. Vivid rosy pink, with white base. A large-sized Darwin of sturdy habit. Height 26 in. 60 cts. per doz., $\$ 4.25$ per Ioo, $\$ 40$ pcr I, 000.

May Queen. Beautiful soft rose; one of the finest of its color. Height 26 in. 50 cts. per doz., $\$ 3.25$ per I oo, $\$ 30$ per I, 0 oo.

MARGARET (Gretchen). Beautiful globular flower; outside blush, inside soft blush-rose. The cup-shaped flower is borne on a strong stem; medium size. Height 22 in. 35 cts. per doz., $\$ 2.25$ per I00, \$20 per I, 000.

Massachusetts. Beautiful light rose; most attractive. Height 26 in. 50 cts. per doz., $\$ 3.25$ per I $00, \$ 30$ per I,ooo.

Massenet (syn. The Dovc). Soft apple-blossom, flushed white, center white; good-sized flower of very delicate beauty. The latest bloomer of all. Height 24 in. \$3 per doz., \$20 per Ioo.
*Mrs. Krelage. A large flower of purplish rose, with a broad margin of blush-pink; on a very tall stem. Stands forcing splendidly and produces a flower of a very pleasing color. Height $28 \mathrm{in}$. $45 \mathrm{cts}$. per doz., \$2.75 per Ioo, \$25 per I,000.

Mrs. Grover Cleveland. Beautiful delicate flesh-color; on a tall stem. Height 24 in. 45 cts. per doz., $\$ 2.75$ per I oo, $\$ 25$ per I, 0oo.

MIRS. POTTER PALMER. Bright purplish violet; large flower. Height 28 in. 70 cts. per doz., $\$ 5$ per I oo, $\$ 48$ per I, 000 .

Noire, La Tulipe. The historic black Tulip. Height 25 in. \$I per doz., $\$ 7$ per I oo, $\$ 65$ per I, ooo.

*PAINTED LADY. Creamy white, flushed light lilac. Very effective when used as a border around a bed of one of the scarlet varieties. Height 27 in. 50 cts. per doz., \$3.25 per I 00, \$30 per I, ooo.

PHILIPPE DE COMMINES. Velvety dark purple; large flower on strong stem. Height 24 in. $55 \mathrm{cts}$. per doz., $\$ 3.50$ per Ioo, $\$ 32$ per I, ooo.

*PRIDE OF HAARLEM. Old-rose flowers of great size and fine form. Most flowers have more than six petals, which gives them a semi-double form. The best Darwin Tulip of its color. Height $3 \mathrm{ft} .45 \mathrm{cts}$. per doz., $\$ 3$ per I00, $\$ 28$ per I, 000 .

Prince of the Netherlands. Glowing cerise-scarlet, flushed salmonrose; extra-large flower. Height 30 in. \$I.50 per doz., \$I o per Ioo.

*Prof. Rauwenhoff. Splendid; salmon-red. Early forcer, and beautiful bedding variety. Height 28 in. $70 \mathrm{cts}$. per doz., $\$ 4.75$ per I 00 , $\$ 45$ per I, 000 .

*PSYCHE. Soft rose; enormous long-stemmed flower. This is one of the Darwins which is even more beautiful when you look into the cup than when you look at the outside of the flower. It is one of the earliest forcers. Height 26 in. $60 \mathrm{cts}$. per doz., $\$ 4$ per I $00, \$ 37.50$ per I, 000 .

Purple Perfection. An extra-fine dark purple. Height 23 in. $\$ 1.25$ per doz., \$9 per I oo.

PYGMLLION. Purplish red; large flowers. 75 cts. per doz., $\$ 5$ per I $00, \$ 48$ per I,000.

Queen of Brilliants. Large, deep; full rose, shaded scarlet. Height 25 in. 60 cts. per doz., $\$ 4.25$ per I0o, $\$ 40$ per I, 000 .

Rev. Ewbank. Heliotrope-lilac, flushed silver-gray. Height 22 in. 55 cts. per doz., $\$ 3.5^{\circ}$ per I0o, $\$ 32$ per $\mathbf{I}, 000$.

REV. HARPER CREWE. Amaranth-red, edged deep mauve; inside brilliant crimson-carmine, with blue base. Height 25 in. \$I per doz., \$7 per Ioo.

RONALD GUNN. Clear violet, with white centers; extra-large flowcr. Height 23 in. 35 cts. each, \$2.25 per doz., \$I 5 per Ioo.

Scylla. Fiery red; a striking variety. Height 26 in. 45 cts. per doz., $\$ 2.75$ per I00, $\$ 25$ per I, 000 .

THE SULTAN. Maroon-black; very showy. Height 25 in. 35 cts. per doz., \$2.25 per I00, \$20 per I, 000.

VALENTIN. Light violet, with electric-blue center; large and bold flower. Height 30 in. \$2 per doz., \$I3 per Ioo.

WHITE QUEEN, or La Candeur. White. Can be called the only white Darwin. It opcns rosy white, but passes to pure white. One of the most popular varieties; forces easily. Height 24 in. 50 cts. per doz., $\$ 3.25$ per I $00, \$ 30$ per I, 000 .

*WILlIAM COPELAND. The best early forcing Darwin. May bc flowered to perfection early in January; its color, when forced, is a delicate lavender. For outdoor planting we do not recommend it, as the color is a common rosy lilac in the open. Height 25 in. 60 cts. per doz., $\$ 4.25$ per Ioo, $\$ 40$ per I, 000 .

Zulu. Blue-black; very distinct form; a splendid and very remarkable flower. Height 32 in. \$I.50 per doz., \$7 per I00, \$65 per I, 000 .

BODDINGTON'S QUALITY MIXED. A fine mixture of all the best named varieties. \$I per doz., $\$ 5.50$ per I $00, \$ 50$ per I, 000 . BODDIIJTON'S SPLENDID MIXED. 35 cts. per doz., $\$ 2.25$ per I0O, \$20 per I, ooo. 


\section{COTTAGE or MAY-FLOWERING TULIPS}

For Planting among Herbaceous Plants and Formal Borders of Shrubbery, etc.

The difference between this class of Tulips and the Darwins is, in some instances. merely a botanical one, of little importance to the horticulturist, consisting of an inconspicuous yellow marking at the base of the petal inside the cup. Some varieties of Cottage Tulips are as large as the Darwins and have petals of obtuse shape. Many of them do not grow so tall as the Darwins, and a majority of the varieties have pointed petals which give the flower a chalice shape, as will be seen in the accompanying illustration of the variety Picotee. They flower in May and June at the same time as the Darwins, and the majority of the varieties are equally desirable.

Bizarres. Handsome, rich flowers, with yellow Doz. Ioo $\mathrm{I}, 000$ ground, feathered or striped with crimson, purple and white. Finest mixed.

Bouton d'Or. Has deep, clear yellow, globular, medium-sized blossoms, with curious black-anthered stamens. Height 20 in. .

Bybloems, Violets. Late Tulips, with white ground, blotched, striped or feathered with lilac, purple, violet, blue or black; extremely handsome and effective. Finest mixed...

Bybloems, Rose shades. Superfine mixed....

CALEDONIA. Bright orange; very beautiful variety. Height 20 in. $40 \mathrm{cts}$. per doz., $\$ 2.50$ per I00, $\$ 22$ per I, 000.

Carmation. White, changing to rose. An improved form of Picotee; larger and more handsome. 55 cts. per doz., $\$ 3.75$ per I00, \$35 per I, 000 .

CYGNET. White, with black anthers, giving the flowers a very distinct appearance. Height 20 in. 60 cts. per doz. $\$ 4.25$ per I 00, $\$ 40$ per I, ooo.

CYCLOPS. Beautiful scarlet, with yellow center and black anthers; very distinct. Height 24 in. 70 cts. per doz., $\$ 4.75$ per I $00, \$ 45$ per I, 000

Chameleon. Pale heliotrope, flaked maroon on a canaryyellow ground; very rare. $\$ 6$ per doz., \$45 per Ioo.

Doris. Large globular flower: lilac-rose flushed silvery gray: very tall. $5^{\circ}$ cts. per doz., $\$ 3.25$ per I $00, \$ 30$ per I, 000 .

Elegans. Dark crimson, beautifully reflexed. Height 15 in. 45 cts. per doz., $\$ 2.75$ per Ioo, $\$ 25$ per $\mathrm{I}, 000$.

ELLEN WILLMOTT. Undoubtedly one of the finest May-flowering Tulips. Flowers very large, beautiful in form and of a soft creamy yellow; very fragrant. Height I 8 in. 65 cts. per doz., $\$ 4.50$ per 100 , $\$ 42$ per I,000.

Flava. Beautiful soft lemonyellow. Fine for massing in beds of single color. Height 25 in. $\$ 1.50$ per doz., $\$$ IO per

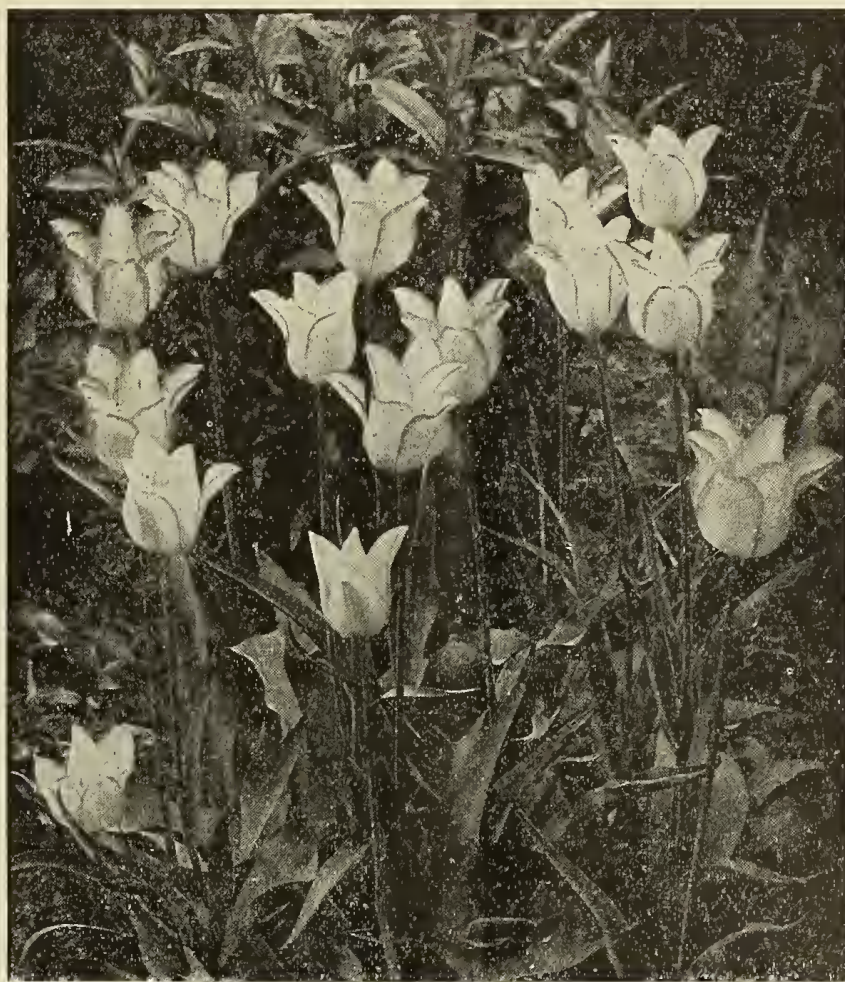

Picotee or Maiden's Blush Tulips scarlet, black base; an excellent variety. Height 20 in. ...

INGLESCOIABE YHLLOW. A large, canaryyellow flower of perfect form, glossy and very beautiful. Height $2 \mathrm{I}$ in......

INGLESCOMBE PINR. One of the best pink sorts. Height 24 in.

Isabella, or Shandon Belis. The petals are Doz. I00 $I, 000$ $\begin{array}{lllllll}0 & 50 & \$ 3 & 25 & \$ 30 & 00\end{array}$ $35 \quad 2 \quad 50 \quad 2200$ a rose color, flushed or flaked with white when they are first open, and after two or

$\begin{array}{lllll}70 & 4 & 75 & 42 & 00 \\ 40 & 2 & 50 & 22 & 00\end{array}$

three days change to a suffused deep rose and red. Remains longer in bloom than many others; stands well when cut. Height 20 in. $30 \mathrm{cts}$. per doz., \$2 per I00, \$I 8 per I, ooo.

La Merveille. A magnificent variety, with very large, sweetscented blossoms. Salmonrose, overlaid with orange-red. A good border variety. Height 20 in. $40 \mathrm{cts}$. per doz., $\$ 2.50$ per I Oo, \$22 per I, 000.

Mrs. Kerrell. Light rose, with dull amber tinge; center white, bordered electric-blue. $\$ 4$ per doz., \$30 per Ioo.

Maiden's Blush, or Picotee. Clear white, margined on the edge with pink. When it opens, the petals are white and margined or penciled with pink to cerise. After two or three days the flowers change to a deep rose, and, unless one is acquainted with it, it would not be recognized as the same Tulip. It stands well when cut. Height 20 in. 30 cts. per doz., $\$ 2$ per I 0o, \$I 8 per I, 000.

MOONLIGHT. A big, ovalshaped flower of unusual substance on a very tall and strong stem. The color is soft yellow and pleasing, like that of moonlight, hence its name. One of the best novelties. Height 25 in. \$I per doz. $\$ 7$ per Ioo.

MRS. MOON. The finest late yellow; beautifully reflexed petals. A charming variety. Height 25 in. \$I per doz., \$6 per I $00, \$ 55$ per I, 000 . I 00.

GALA BEAUTY, or COLUMBIA. Blotched Doz. I0o
vermilion and golden yellow. Height 20 in $\$ 2$ oo $\$ 15$ oo

Gesneriana spathulata or major. This variety has lon $\mathrm{g}$ been in cultivation. The beautifully curved flowers are brilliant scarlet, with a bluish black center, on tall stems. Height 24 in.

Gesneriana macrospeila. Crimson-scarlet, black and yellow center. Height 24 in. .

Gesneriana lutea. Beautiful yellow; tall and handsome. Height 24 in.

Gesneriana ixioides. Beautiful yellow, with black center. Height 22 in.

Greigii. The beautifully formed flowers are of large size and of a gorgeous orange-scarlet color, so brilliant as at once to attract the attention. The plant is quite ornamental. on account of its broad, spotted foliage. Height 9 in...
I,OOn

Parisian White (La Candeur).
ing to light pink. Height 6 in ing to light pink. Height Io in changing to white. Height I 6 in

Royal white. Pure white with yellow cent Height $I 5$ in...

$\begin{array}{lllll}35 & 2 & 25 & \$ 20 & 00 \\ 25 & \text { I } & 75 & \text { I } 5 & 00 \\ 45 & 2 & 75 & 24 & 00 \\ 25 & 9 & 00 & & \end{array}$

Striped Beauty. Rose, flaked deep crimson and white; immensely pretty. Height I 8 in.

THE FAWN. Very large, oval flower; light grayish rose, changing to soft rosy white. Height 20 in.

Vitellina. Pale primrose, passing off to pure white; tall and exceedingly handsome. Height 20 in. .

Boddington's "Quality" Superfine Mixture of May-flowering Tulips, for accliinating and for planting in herbaceous or shrubbery borders. .

\begin{tabular}{|c|c|c|}
\hline 40 & $\begin{array}{c}100 \\
\$ 250\end{array}$ & $\begin{array}{r}1,000 \\
\$ 2200\end{array}$ \\
\hline 45 & 300 & 2800 \\
\hline 60 & 400 & .3700 \\
\hline 50 & $\begin{array}{ll}325 \\
\end{array}$ & 30 \\
\hline
\end{tabular}

$\begin{array}{lllll}50 & 3 & 25 & 30 & 00\end{array}$

$\begin{array}{lllll}50 & 3 & 25 & 30 & 00\end{array}$

30 I 75 I 5 oO 


\section{Parrot or Dragon Tulips}

Parrot Tulips flower in May. Their marvelously striped and colored petals have slashed edges. The bulbs should be planted not more than 4 inches apart, as they are lather shy bloomers. Admiral de Constantinople. Large; red, Doz too Cramoisi Brillant. 'Rich blood-crimson. with bluish markings. T.000

Lutea major. Large; showy yellow.

Markgraaf von Baden. Red and yellow, orange inside; very showy.

Perfecta. Yellow, striped red.

Boddington's “Quality" Superfine Mixed Parrot Tulips.

\section{Rembrandt Tulips}

Rembrandt Tulips are simply queerly striped and feathered Darwin Tulips. They resemblc Bybloems, but are larger, and there is more variety in the colors.

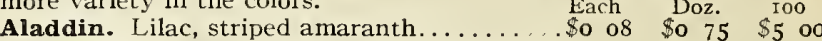

Crimson Beauty. Carmine and white, flamed

dark red.......................... $08 \quad 75 \quad 500$

La Coquette. Lilac and white, striped black;

very handsome. .

Purity. Almost entirelv white, with delicate

Titania. Rosy lilac and white, striped red...

Victor Hugo. Carmine, flamed white......

Mixed Superfine..............,

\section{$08 \quad 75 \quad 500$}

$08 \quad 75 \quad 5 \quad 00$

$08 \quad 75 \quad 500$
$08 \quad 75 \quad 500$

\section{Breeder Tulips-Self-Colored}

To those in search of the unusual for group-planting in the perennial border, the Breeder Tulips (flowering in late May) present a fascinating choice. The most refined and artistic color combinations and soft blendings and graduations of purple, buff, bronze, maroon, and terra-cotta are here revcaled to the garden enthusiast exploring this class.

Breeder Tulips are noticeably sweet scented. They are closely allied to the Darwins and some of the varieties bear even larger flowers and are of more vigorous growth than that well-known class. Cultural directions same as for Darwin Tulips.

Bronze Queen. Large flowers; light bronze. Height 28 in. Io cts. Marie Louise. Old-rose flushed orange-salmon. Height 23 in. I 2 each, \$I per doz., \$6.50 per Ioo.

Cardinal Manning. Dull wine-red and bronze; an enormous flower of a peculiar color. Height 30 in. $7 \mathrm{cts}$. each, $60 \mathrm{cts}$. per doz., $\$ 4$ per IOO.

Dom Pedro. A very beautiful bronze variety. Height 24 in. $30 \mathrm{cts}$. each, \$3 per doz., \$23 per roo.

Faery (Panorama). Reddish mahogany; extra large. I5 cts. each, $\$ 1.50$ per doz., \$I o per Ioo.

Godet Parfait. Bright violet with white base; very large bloom. Height 30 inches. I 2 cts. each, \$1.25 per doz., \$9 per Ioo.

Jaune d'Oeuf (Sunrise). Orange-red. Height $2 \mathrm{I}$ in. 7 cts. each, 60 cts. per doz., $\$ 4$ per Ioo.

Louis XIV. Dark purple, with broad margin of gold. One of the best. Height 30 in. $75 \mathrm{cts}$. each, $\$ 7.50$ per doz., $\$ 50$ per 100

LUCIFER. Bright terra-cotta-orange; very pretty. Height 20 in. $25 \mathrm{cts}$. each, $\$ 2.50$ per doz., \$I per IOO.
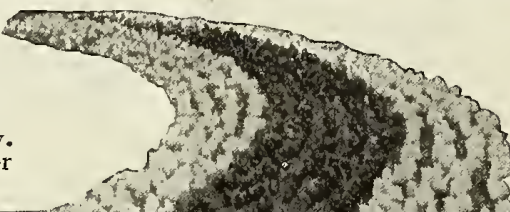

VELVET KING. Shining purple; enormous flowers. Height 25 in. 20 cts. each, $\$ 2$ per doz., \$I 5 per 100.

Yellow Perfection. Light bronzy yellow, edged golden yellow. Height 24 inches. I 5 cts. each, \$1.50 per doz., \$IO per 100.

Mixed Superfine. $5 \mathrm{cts}$. each, $45 \mathrm{cts}$. per doz., $\$ 3$ per $100, \$ 28$ per 1,000 .

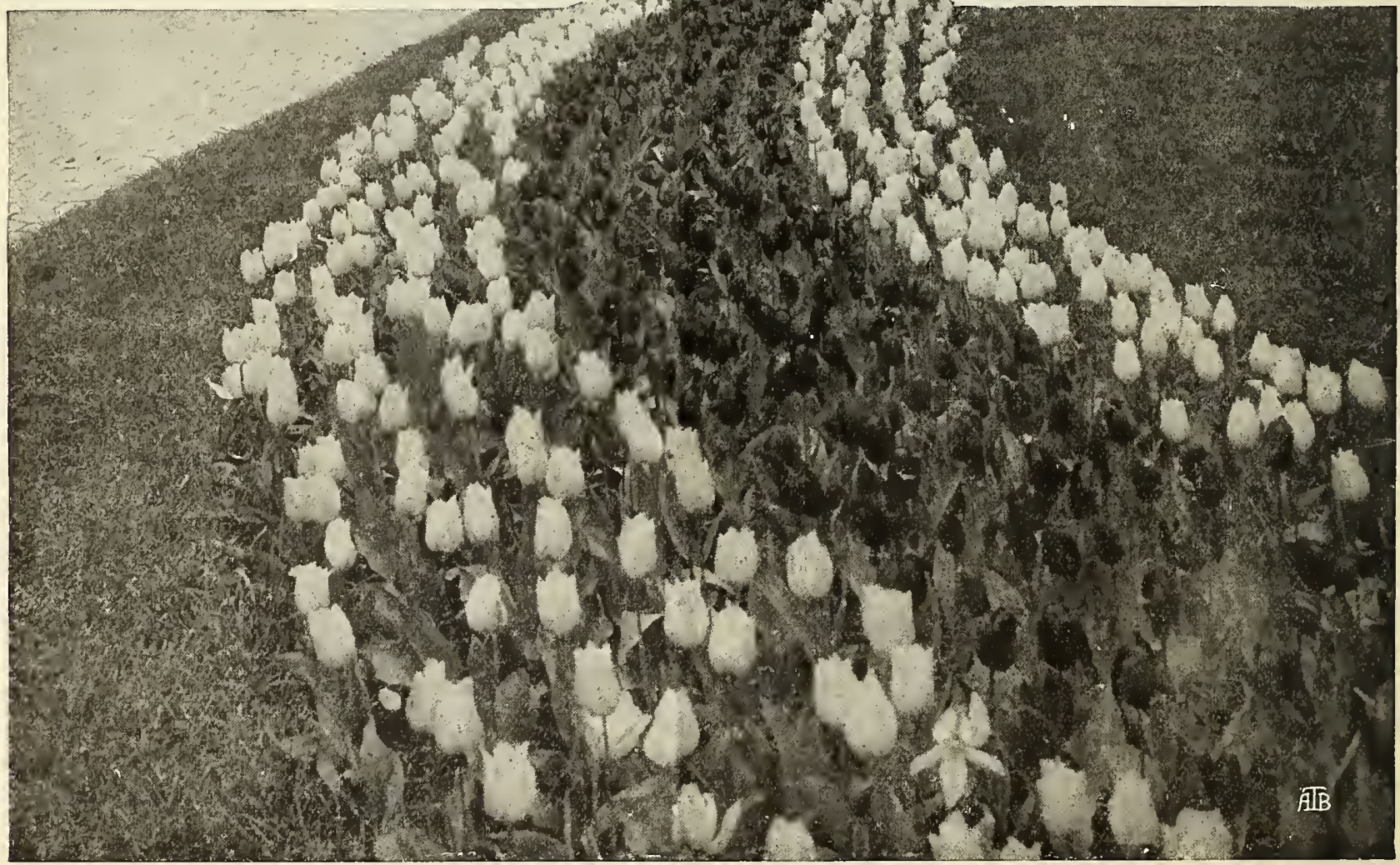




\section{BODDINGTON'S EARLY TULIPS}

FOR BEDDING OR FORCING. FIRST-SIZE FLOWERING BULBS ONLY

\section{CULTURAL DIRECTIONS}

Tulips in Pots and Pans.--Seven bulbs planted in a 6-inch pan are very satisfactory. It is important in the pot culture of Tulips to have rich, light soil. Cover the hole in the pot with a piece of broken pot, and over this place a half-inch layer of moss or grass roots which will keep the soil from clogging the drainage thus provided. In potting, place each bulb so that its top shall be half an inch below the surface of the soil and an inch below the rim of the pot. The soil should be of usual natural moisture and should be pressed moderately firm. The filled pots may be placed in a coldframe where there is protection from frost or in the coolest part of the cellar; keep well waterea. In many houses the furnace will keep the cellar too warm. An excellent plan is to place them on a bed of moist, sifted coal-ashes, covering the pots to a depth of 6 inches with the same material. When well rooted, which will be in about twelve to fourteen weeks, the bulbs may be brought indoors and forced. For the first two or three weeks they should be be kept in a temperature not exceeding 50 degrees. Success in forcing depends much on their having strong roots before being brought to the light. The top grows rapidly, and unless the roots are started much in advance they are unable to nourish the plant, and failure results. Tulips for forcing must be potted in September or October. The blooms last much longer if shaded from the sun after they show color. The varieties preceded by a star $(*)$ are the best for forcing.

Outdoor Cultuxe. There is one important difference between hyacinths and Tulips. Under similar treatment most hyacinths flower about the same time, while Tulips come into bloom at successive periods. The divergence has frequently been the source of much disappointment, for, in a bed (or even a vase or pot) planted with different Tulips, one variety may be overblown before the others show their colors.

The figures following the varieties indicate earliness in flowering, No. I being the earliest; No. 2 following; No. 3 being still a little later, but coming into bloom before the No. 2's are out. The height is indicated by " $D$ " for dwarf, "M" for medium, "T" for tall. Tulips for bedding should be planted about 6 inches apart and about 4 inches deep, reckoning from the tops of the bulbs.

\section{Arrangements of Color Schemes for Bedding, etc.}

For brilliant bedding effects, solid masses of color are to be preferred, especially for design bedding.

Prince of Austria and Vermilion Brilliant.

Chrysolora and Belle Alliance.

Couleur Cardinal. Bedded by itself makes one of the most beautiful beds.
Duchesse de Parma and La Reine. La Reine and Artus.

Maes. Unsurpassed when bedded alone. Pottebakker White and Chrysolora.

\section{Pink Beauty and Ophir d'Or.}

Rose Gris-de-Lin. Separate in one bed.

Keizerkroon. Makes a unique bed. Cramoisi Brillant and Ophir d'Or.

\section{Single Scarlet and Crimson}

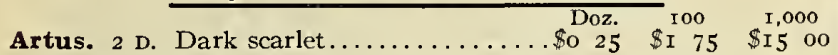

*Belle Alliance. 2 D. Scarlet; good bed-

* Couleur Cardinal. 3 T. Crimson-scarlet...

Cramoisi Brillant. 3 T. Bright scarlet....

Crimson King. 3 D. Crimson; showy bedder.

*Duc Van Thol Cochineal. I D. Scarlet; earliest of all.

Dusart. Deep vermilion; of very large size. .

* Maes. I м. Bright scarlet; large flower...

*Pottebakkex Scarlet. 2 T. Bright scarlet; good forcer; very fine...............

Sir Thomas Lipton. 2 T. Beautiful one of the finest bedders..............

*Vermilion Brilliant. 2 let and vermilion; excellent for pots; showy bedder.....

\section{Single White}

*Duc Van Thol White (Maxima). I D. Very

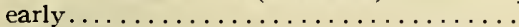

*Lady Boreel. (True.) $2 \mathrm{M}$. Pure white; an excellent forcer..................

* La Reine, 2 м. White, slightly rose-shaLa Reine. ded; good forcer and bedder..

*La Reine. 2 м. Top roots

*Pottebakker White. 2 T. Pure white; large, showy flower; splendid for forcing........

*White Hawk. (True.) 2 T. Very large; Washington. $2 \mathrm{M}$. Silvery white; fine bed-

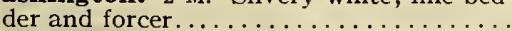

White Swan. (True.) 2 T. Long-stemmed, pure white egg-shaped flower; one of the best whites...... $\begin{array}{lllll}45 & 2 & 75 & 25 & 00\end{array}$

$\begin{array}{lllll}60 & 4 & 25 & 39 & 00\end{array}$

$30 \quad 2$ OO $\quad$ I 8 OO

25 I 50 I 4 O0

$\begin{array}{lllll}45 & 2 & 75 & 25 & 00\end{array}$

$\begin{array}{lllll}35 & 2 & 25 & 20 & 00\end{array}$

$45 \quad 300 \quad 2200$

$\begin{array}{lllll}35 & 2 & 25 & 20 & 00\end{array}$

$60 \quad 4 \quad 25 \quad 40$ oo

$\begin{array}{lllll}55 & 3 & 75 & 35 & 00\end{array}$

$\begin{array}{llllll}35 & 2 & 25 & 20 & 00 \\ 55 & 3 & 75 & 36 & 00 \\ 35 & 2 & 25 & 20 & 00\end{array}$

$40 \quad 250 \quad 2400$

50 $325 \quad 3000$

$45 \quad 300 \quad 2700$

$\begin{array}{llll}35 & 2 & 25 & 20\end{array}$

25 I 75 I 5 oO

\section{Single Pink and Rose}

*Cottage Maid. 2 2 . Rosy pink, white for bedding and forcing...

*Duc Van Thol Rose. I D, Early. .

* Flamingo. 2 m. Carmine-rose, whiterlamingo. shaded.

*Jenny. $2 \mathrm{M}$. Beautiful velvety carminerose. On the middle of the petals a y white stripe, broadening toward the base. One of the best novelties in Tulips. Forces very easily and is a very bright bedder

* Le Matelas. 2 м. Splendid bright rose, McKinley, 2 т. Silky rose, shaded carMcKinley. mine outside. Large flower. Can be forced very early. An improved Prosperine. 100 $x, 000$ Pink Beauty. 3 T. A lovely Tulip; bold, snowy white flush on outer petals, center white and yellow.

* Proserpine. 2 M. Large, rich, silky rose; ${ }^{*}$ Queen of the Netherlands. ${ }^{2} \mathrm{M}$. cate, rosy blush-pink. There is no other pink in Tulips that approaches the delicate color of this Tulip, when it is forced slowly. When forced too hard the color is too pale. The flowers are large and well formed and, when properly grown, it is one of the best Tulips we know of . .

$\begin{array}{lllll}40 & \$ 2 & 25 & \$ 19 & 00\end{array}$ $30 \quad 2$ oo $\quad$ I 8 oo $\begin{array}{lllll}75 & 5 & 25 & 50 & 00\end{array}$ Queen of Pinks. 2 M. One of the best bordered with bright pink. Good for forcing and bedding.

Rose Gris-de-Lin. 2 D. Delicate pink, tinged white; good forcer

Rose Luisante. 3 M. Deep pink; a highclass, showy variety........... Bright pink; Rosa Mundi Huyckman. 3 M. Bright pink;

$\begin{array}{lllll}45 & 2 & 75 & 25 & 00 \\ 25 & \text { I } & 75 & \text { I } 5 & 00 \\ 55 & 3 & 50 & 3 \text { I } & 50 \\ 40 & 2 & 50 & 2 \text { I } & 00\end{array}$




\section{Single Yellow Tulips}

*Canary-Bird. 2 M. Clear yellow; large Doz.

flower; early.........................
* Chrysolora. 2 M. Pure yellow; handsome flower.

Cottage Boy. 2 D. Bronze-yellow, with tage Maid. A very showy and excellent bedder with large flowers

*Duc Van Thol Yellow. I D. Golden yellow; very early.

* Goldfinch. 2 D. A very fine, pure yelform, good for bedding or forcing handsome

*olden Queen. 2 T. A most beautiful pure yellow, very large and of graceful globular form

King of the Yellows. ${ }^{2}$ T. Deep

* Mon Tresor. 2 M. Pure yellow; large cup; handsome; good forcer

Ophir d'Or. ${ }^{2}$ м. Rich golden yellow; of large size and fine form.

*Pottebakker Yellow. (True.) 2 T. Large; pure yellow

*Rising Sun, 2 T. Very large flower of stem, color deep golden yellow. Created a sensation at the New York Flower Show in the spring of I9I7.

* Yellow Prince. 2 D. Pure yellow; good for bedding or forcing.
$100 \quad T, 000$ $\$ 2 \quad 75 \quad \$ 24$ o0 $\begin{array}{lllll}35 & 2 & 25 & 20 & 00\end{array}$

50 $325 \quad 2800$

$\begin{array}{lllll}35 & 2 & 25 & 18 & 00\end{array}$

$\begin{array}{lllll}40 & 2 & 50 & 21 & 00\end{array}$

$\begin{array}{lllll}55 & 350 & 32 & 00\end{array}$

$40 \quad 2 \quad 50 \quad 22 \quad 50$

$\begin{array}{lllll}50 & 3 & 25 & 30 & 00\end{array}$

$\begin{array}{lllll}40 & 2 & 50 & 22 & 50\end{array}$

$\begin{array}{lllll}35 & 2 & 25 & 20 & 00\end{array}$

OO I5 00

$\begin{array}{llllll}40 & 2 & 50 & 21 & 00\end{array}$
Single, Striped, Variegated and Purple

*Clusiana. I D. This Tulip has becn in Doz. I00 I,000 It is the cultivation since about $\mathrm{I}_{634}$ hero of Balzac's "The Quest of the Absolute." Quaint and unusual. Color white,

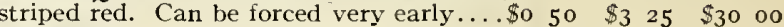

*De Wet. 2 r. Golden yellow, striped fiery

when forced. Sensation at the International

Flower Show, New York, $1916 \ldots \ldots \ldots \ldots 5$ oo 4000

Duch esse de Parma. 2 M. Orange-red, yel-

low shaded; large flower.

*Duc Van Thol, Red and Yellow. I D. Fine for very early effects.............. Joost Van Vondel. 2 M. Very handsome red, feathered white.................

*Keizerkroon. 2 T. Red, with broad yelive. Extra top roots; the best stock for forcing or bedding. .....................

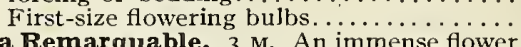

La Remarquable. 3 M. An immense flower of great substance; silky plum, shading off to silvery pink at the edges; yellow base.

*Prince of Austria. $3 \mathrm{r}$. Orange-vermilion;

large; fine for forcing or bedding.........

Thomas Moore. 2 r. Apricot-orange; fine variety; sweet scented..............

Wouverman. 2 M. Dark violet; a unique

$\begin{array}{lllll}40 & 2 & 50 & 21 & 00 \\ 30 & 2 & 00 & 18 & 00 \\ 40 & 2 & 50 & 22 & 50 \\ & & & & \\ 50 & 3 & 25 & 30 & 00 \\ 45 & 2 & 75 & 25 & 00 \\ 70 & 4 & 75 & 45 & 00 \\ 45 & 2 & 75 & 25 & 00 \\ 35 & 2 & 25 & 20 & 00 \\ 60 & 4 & 25 & 40 & 00\end{array}$

Boddington's Fine Mixed Single Tulips

An extra-fine mixture of good bedding Tulips for planting. $25 \mathrm{cts}$. per doz., \$I.75 per I00, \$1 5 per I,000.

\section{BODDINGTON'S "QUALITY" NAMED DOUBLE TULIPS}

The value of Double Tulips lies chiefly in their lasting qualities. Thcy lack the length of stem and grace of the Singles; nevertheless, we know of no Tulips more beautiful than some of the Doubles, especially when flowered in pots or pans. They cannot be flowered so early as the Singles, and no attempt should be made to force them into bloom before the middle of March. For cultural directions see Single Early Tulips. When forcing Double Tulips, we advise to let them come slowly at first, to prevent them from getting green-tipped.

\section{Double Red}

* Imperator Rubrorum. 3 3 M. Hand-D scarlet;

$100 \quad \mathrm{I}, 000$

showy and lasting. One of the older double

scarlets that holds its own wonderfully

well among the many newer red varieties. .\$o 55

*Rex Rubrorum. 3 м. Bright scarlet.....

*Vuurbaak. 3 M. Brilliant scarlet...........

Le Matador. 3 м. Brilliant scarlet, good flower.

\section{Double Yellow}

*Couronne d'Or (Crown of Gold). $3 \mathrm{M}$. one of the finest for forcing, eicher for pots or pans. Makes a brilliant effect when massed in a largc bed.

*Tournesol Yellow. $3 \mathrm{D}$. One of the best double yellows. Very large flowers; fine for late bedding.

Yellow Rose. 3 м. Rich yellow; very fragrant; large flower

\section{Double Pink}

Couronne des Roses 3 m. Delicaterose; a beautiful variety

*La Grandesse. 3 M. Deep rose..........

Lord Beaconsfield. 3 м. Deep rose.

Lucretia. 3 M. Splendid deep pink; large flowers. Good for forcing. ..............

* Murillo. $3 \mathrm{M}$. Magnificent blush-white Top roots

*Rose d'Amour. 3 M. Beautiful soft rose; Tulip has come to be one of the most popular for forcing or for outdoor planting.....

$\$ 350 \$ 3100$ $\begin{array}{lllll}45 & 2 & 75 & 25 & 00\end{array}$ $400 \quad 3600$

50 $325 \quad 30 \quad 00$

DOUBLE PINK, continued

Rosea Perfecta. $3 \mathrm{M}$. Round-formed Doz. roo $\quad$ I,000

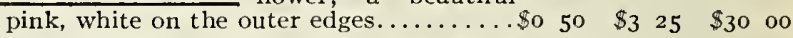
*Salvator Rosa. 3 M. Deep rose, striped 50 $325 \quad 30$ o0

*Tea Rose. 3 м. A pale yellow sport from Safrano-yellow light orange at the tips of the petals. It is a splendid variety for growing in pans.

$65450 \quad 4200$

\section{Double Striped and Oddly Colored}

*Tournesol, Red and Yellow. 3 D. Good Doz. 100 I,000 forcer and bedder................\$o $60 \quad \$ 4$ oo $\$ 36$ oo

*Toreador. $3 \mathrm{M}$. Bright scarlet, margined

Titian. $2 \mathrm{M}$. Scarlet, edged yellow; a most charming variety................ $55 \quad 3 \quad 75 \quad 3500$

\section{Double White}

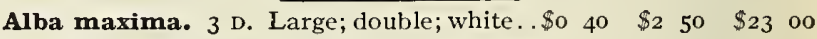
* Boule de Neige. 3 m. Pure white; one

$\begin{array}{lllll}70 & 4 & 75 & 45 & 00 \\ 35 & 2 & 25 & 20 & 00 \\ 50 & 3 & 25 & 30 & 00 \\ & & & & \\ 45 & 3 & 00 & 26 & 00 \\ & & & & \\ 40 & 2 & 50 & 22 & 00 \\ 45 & 2 & 75 & 25 & 00\end{array}$

\section{* Blanche Hative. 3 m. A superb white;}

La Candeur. 3 M. Pure white; a splendid bedder, which holds its flowers a long time.

\section{$50 \quad 3 \quad 25 \quad 30$ oo \\ $\begin{array}{lllll}45 & 2 & 75 & 25 & 00\end{array}$ \\ $40 \quad 250 \quad 2200$}

Comprises only the best bedding varieties in equal proportions, and contains a splendid assortment of showy colors. $30 \mathrm{cts}$. per doz. $\$ 2$ per I00, \$18 per I, 000. 


\section{Boddington's Extra-Selected Named Dutch Hyacinths}

\section{CULTURAL DIRECTIONS}

HYACINTHS IN POTS. It is important in the pot culture of Hyacinths to have rich, light soil. If the bulbs are to be potted singly, pots 5 inches in diameter are the proper size. Cover the hole in the pot with a piece of broken pot, and over this place a layer of moss, which will keep the soil from clogging the drainage thus provided. Break off any offsets which appear at the base of the bulbs, and, in potting, place each bulb so that its top shall be half an inch below the surface of the soil and an inch below the rim of the pot. The soil should be of usual natural moisture, and should be pressed moderately firm. The filled pots may be placed in a coldframe where there is protection from frost, or in the coolest part of the cellar, and well watered. An excellent plan is to place them on a bed of moist, sifted coal-ashes, covering the pots to a depth of 6 inches with the same material. When well rooted, which will be in about ten weeks, the bulbs may be brought indoors and forced. For the first two or three weeks they should be kept in a temperature not exceeding 50 degrees. Success in forcing depends much on their having strong roots before being brought to the light. The top grows rapidly, and unless the roots are started much in advance they are unable to nourish the plant, and failure results.

Hyacinths for early use may be potted in September or October. When desired for late use, it is better to pot them in October and keep them in a coldframe or cellar above freezing until it is desired to force them into bloom. To obtain dwarf foliage and fine flower-spikes, Hyacinths, when being forced, should have plenty of manure-water and fresh air, and should have as much light as possible. The blooms last much longer if shaded from the sun after they show color.

\section{PRICES OF DUTCH HYACINTH BULBS}

Boddington's “Top-Root" Named Dutch Hyacinths, purchaser's selection of varieties .

Boddington's Strictly First-size Named Dutch Hyacinths.

Boddington's Strictly Second-size Named Dutch Hyacinths

Boddington's Third-size or Named Bedding Dutch Hyacinths.

\section{SINGLE WHITE AND TINTED}

Albertina. Pure white; very fine.

British Queen. Very fine, pure white.

Grandeur a Merveille. Finest blush-white; immense truss.

Grande Blanche. Blush-white; very large bells; excellent truss.

GENERAL VETTER. A grand white variety.

L'Innocence. Pure white; extra large.

La Grandesse. Finest pure white; large bells.

MR. PLIMSOLL. Ivory-white; fine bells; very showy.

Mme. Van der Foop. Pure white; large truss; dwarf; late.

QUEEN OF ENGLAND. Pure white; large bells; early.

\section{SINGLE RED, ROSE AND PINK}

CARDINAL WISEMAN. Bright rose; large flower.

ETNA. Brilliant pink; very large bells; late.

GENERAL DEWET. Light pink; also called the pink Grand Maitre.

GENERAL PELISSIER. Deep crimson; fine truss; early.

Gertrude. Rosy pink; compact truss.

Gigantea. Blush-rose; large; close truss.

Garibaldi. Glossy crimson; good truss; very early.

Jacques. Delicate pink; very large spike.

KOHINOOR. Bright pink; extra-large truss; one of the largest flowers; semi-double.

LADY DERBY. Most beautiful light pink.

LA VICTOIRE. Immense, brilliant red truss of the most perfect form.

Moreno. Waxy pink; large bells and truss.

Ornement Rose. Light rose; superb flower.

QUEEN OF THE PINKS. Lively pink. This is a sport of the wellknown King of the Blues.

Rosea Maxima. Lovely pink; grand bloom.

Roi des Belges. Fine, deep red.

VICTOR EMANUEL. Brilliant red; large truss; early.

\section{SINGLE BLUE, PURPLE AND VIOLET}

BISMARCK. Light sky-blue; blooms very easily at Christmas. The earliest blue Hyacinth.

Czar Peter. Large; porcelain-blue, lighter center; grand truss.

ELECTRA. Porcelain-blue; enormous flower.

ENCHANTRESS. Very delicate porcelain-blue.

Grand Lilas. Light porcelain-blue; good variety for early forcing.

Grand Maitre. Deep porcelain-blue; large truss.

Johan. Pale blue-gray; large bells; splendid, compact spike.

King of the Blues. Rich, dark blue; splendid, well-finished truss.

L'Esperance. Dark purple; splendid bedding variety.

Lord Balfour. Deep violet; very early; enormous truss. The best of the violets.

Marie. Deep blue; large truss.

MENELIK. The darkest of all the blues; immense truss.

For prices of Hyacinths, "Top-root," First, Second and Third or Named Bedding Sizes, see above, and bear in mind that our prices include transportation charges when cash accompanies the order
SINGLe BLUe, PURPLE AND VIOLET, continued

PERLE BRILLANT. Light, brilliant blue; an excellent all-round variety.

Pieneman. Brilliant light blue; large, broad truss.

Potgieter. Light blue; excellent variety.

Queen of the Blues. Porcelain-sky-blue; large bells and fine spike. Regulus. Porcelain-blue; large bells.

SCHOTEL. Pale blue; good forcer.

Sir William Mansfield. Violet; splendid truss; one of the best in its color; splendid bedder.

\section{SINGLE YELLOW AND ORANGE}

CITY OF HAARLEM. Golden yellow; extra-large flower; one of the best of the yellows.

Ida. Pure, light yellow; large truss; early.

King of the Yellows. Pure, deep yellow; large truss.

MacMahon. Nankeen-yellow; fine.

MARCHIONESS OF LORNE. Orange-yellow; very fine spike.

Yellow Hammer. Golden yellow; the finest single of its color.

\section{DOUBLE WHITE AND TINTED}

Bouquet Royal. Pure white, yellow center; good truss.

GRAND VAINQUEUR. Pure white; early.

Isabella. Blush-white; large bells; very fine.

La Tour d'Auvergne. Pure white; good bells; large truss; extra.

\section{DOUBLE RED, ROSE AND PINK}

CHESTNUT FLOWER. Rose; large truss; very beautiful.

Le Grand Concurrent. Beautiful pale rose; large bells and truss; extra.

Lord Wellington. Delicate rosy blush; large bells and truss; one of the best.

PRESIDENT ROOSEVELT. Fine, dark pink; a strenuous variety; large bells; early.

Prince of Orange. Rose-red; semi-double; a beautiful variety.

\section{DOUBLE BLUE AND PURPLE}

Bloksberg. Pale porcelain-blue; grand.

Garrick. Bright blue; very large bells.

GENERAL KOHLER. Bright blue; extra fine; an excellent variety. Van Speyk. Light blue; large bells and truss.

\section{DOUBLE YELLOW}

Goethe. Light yellow; large bells; fine spike.

Jaune Supreme. Deep yellow, salmon tinted.

SIR ROLAND HILL. Pure, dark yellow; large bells; very fine.
La Grandesse. The double form of this well-known variety. 


\section{Boddington's "Quality" Bedding Hyacinths to Color}

Bedding Hyacinths should be planted about 8 inches apart each way-or, say twenty to the square yard-and 4 or 5 inches deep, reckoning from the top of the bulb. The actual number requisite for a given area, however, must be determined in every instance by the local conditions and the object in view; a large bed in the distance need not be so closely planted as a small bed in the immediate foreground, and of course a smaller number will be necessary in either case if a groundwork such as Myosotis, Pansies or Arabis be provided. Hyacinths planted alternately with Narcissi produce a striking effect; for this combination 6 inches from bulb to bulb is a suitable distance.

The following Hyacinths, although offered at very low prices, have all been imported by us from Holland this year and can be strongly recommended for their high quality. They are specially adapted for groups in borders and shrubberies, where they will give a brilliant display of very handsome flowers; but for beds, where uniformity of shade is of importance, we recommend the named budding Hyacinths offered on the preceding page.

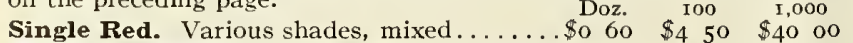

Single Dark Blue. Various shades, mixed.... 60 r 450 50 40

Single White. Various shades, mixed.......6 60 4 50 40 oo

Single Yellow. Various shades, mixed.......6 6045040 oo

Single Pink and Rose. 1 Various shades, mixed. . $60 \quad 4 \quad 50 \quad 40$ oo

Single Light Blue. Various shades, mixed.... 60
Single Blush-White. Various shades, mixed.
S

Single All Colors, Mixed...............6 $60 \quad 4 \quad 50 \quad 40$ oo

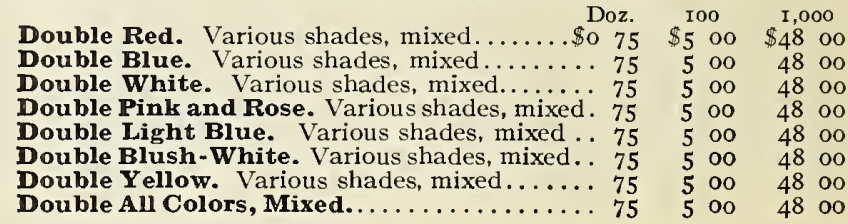

\section{Boddington's Dutch Roman or Miniature Hyacinths}

These are small bulbs, or Miniature Dutch Hyacinths, and are now very largely used for growing in pans or pots. They are also used extensively for bedding purposes, as they produce large spikes of flowers. We can specially recommend our "Quality" Dutch Romans to those who have never grown them, and therefore do not know their value. They consist of named sorts, similar to regular first-size Dutch Hyacinths, of the finest grade and true to name. I 2 to 5 centimeters in circumference.

Albertina. Pure white.

Czar Peter. Light porcelain-blue.

Gertrude. Rosy pink.

Gigantea. Daybreak-pink.

Grand Maitre. Deep porcelain-blue.

Grandeur a Merveille. Blush-white.
Johan. Pale blue.

King of the Yellows. Pure, deep yellow. Lady Derby. Beautiful light pink.

La Grandesse. Pure white.

L'Innocence. White; one of the best.

Mme. Van der Hoop. Best late white.
Moreno. Waxy pink.

Queen of the Blues. Sky-blue; fine.

Roi des Belges. Bright red.

Schotel. Pale blue.

Yellow Hammer. Finest golden yellow.

Any of the above, 50 cts. per doz., $\$ 3$ per $100, \$ 28$ per 1,000

\section{Grape, Feathered, and Musk Hyacinths (Muscari)}

These Hyacinths will grow in any good garden soil, and are admirably adapted for borders that are shaded by trees, also make excellent pot-plants.

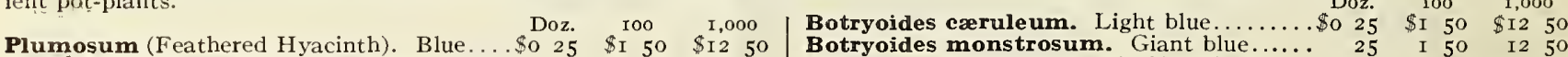

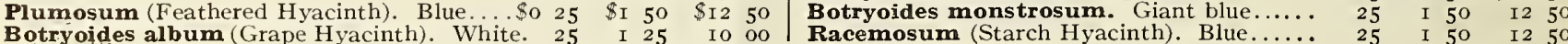

\section{NARCISSI AND DAFFODILS}

\section{Polyanthus or Bunch Flowered Narcissi}

These Narcissi are not hardy, and must not be subjected to frost at any time. For culture, see Narcissus Paper-White, page II.

Chinese Sacred. White, yellow cup. Top Doz. Ioo I,000

roots ................25 cts. each. \$2 $50 \$ 2000$

Chinese Sacred. First-size bulbs. I $5 \mathrm{c}$. each.. I 50 I0 oo

Double Roman. White flowers, yellow cup. . $\quad 35 \quad 2 \quad 25$

Grand Soleil d'Or. See page I I.

Grand Monarque. White flower, yellow cup.

Grand Primo. Large, white flower, citron

cup.

Paper-White Grandiflora. See page I I

Staten General. Large, white flower...... $60 \quad 3 \quad 50 \quad 3000$

The above can be grown in bowls of water or in our prepared fiber

\section{Tonquils $\begin{gathered}\text { Narcissus } \\ \text { Jonquilla }\end{gathered}$}

Doz.

Single Sweet-scented. Deep yellow......

Giant Campernelle. Large; yellow...

Rugulosus. Very fragrant, large Jonquils.

Double-nosed bulbs. XXX

\section{Hoop Petticoat Narcissi}

Bulbocodium conspicuum (Yellow Hoop Doz.

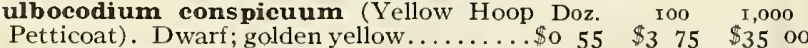

Bulbocodium eitrinum (Sulphur Hoop

Petticoat). Flowers pale citron-yellow.....

Bulbocodium monophyllum (Clusii).

$\begin{array}{lllll}55 & 3 & 75 & 35 & 00\end{array}$

The pure white Hoop Petticoat.

\begin{abstract}
........ I oo
\end{abstract}
750

7000

\section{Chalice-Cup or Star Narcissi}

Barrii, Conspicuus. Large soft yellow peri- Doz. anth; short cup, edged orange-scarlet........

Incomparabilis, Stella. Large, white peri-

anth; yellow cup...................... Primrose peri-

anth, changing to white; cup stained orange.

Incomparabilis, Figaro. Perianth prim-

rose-sulphur; cup bordered orange-red......

Leedsii, Mrs. Langtry. Broad white perianth

and large white cup, edged bright yellow...

Leedsii, Queen of England. Beautiful large flowers, with fine, fringed, citronyellow cup.

Cup Nareissi, Mixed. Many varieties . . . . .

30. $\$ 2 \quad$ IOO

35

225

1,000

35

225

35

225

2000

30200

I9 00

$\begin{array}{llllll}35 & 2 & 25 & 20 & 00\end{array}$

25 I 75 I 5 OO

\section{Poet's Narcissi}

Poeticus (type) (Pheasant's Eye, or Poet's Narcissus). Mother bulbs................. of fine substance with broad, white perianth. cup deeply rimmed dark red... Each, 2oc...

Poeticus, Horace. Broad snowy white perianth; large cup deeply edged blood-scarlet. Very beautiful.............Each, 20c..

Poeticus, King Edward VII. Snow-white petals and beautiful shape; cup canaryyellow, bordered red.

Poeticus ornatus. An improved Poeticus. Pure white perianth, distinct red crown. Top roots (3 flowers). XXX.
25 I 60

I 400

75 I 2 oo

200 I 5 OO

55

375

3500

$40 \quad 250$

2200 


\section{NARCISSI AND DAFFODILS, continued}

The commercial florists have been foremost to give the Narcissi or Daffodils the attention due them. They have learned how easily and successfully these lovely flowers may be forced into bloom during the winter, and how fascinating the blossoms are when planted in colonies in the borders or grouped in the lawn. They may be planted in pots or bulb-pans 6 inches or more in diameter, several bulbs in each, according to size. Treat in the same manner as hyacinths.

\section{Giant Single Trumpet Narcissi}

Albicans. Perianth white, trumpet Each Doz. I00 I,000

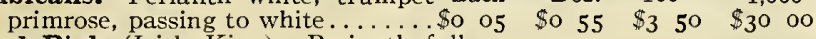
Ard Righ (Irish King). Perianth full yellow, trumpet deep yellow; one of

the best of the Trumpet varieties.... 06

Emperor. A noble single Narcissus; pure golden yellow, of very large size, with immense trumpet.

First-size round bulbs. $\mathrm{X} \ldots \ldots \ldots \ldots$ of

Double-nose bulbs (2 flowers). $\mathrm{XX}$. . o6

Top roots (3 flowers). XXX...... 07

Empress. Pure white perianth, with rich yellow trumpet; a splendid variety.

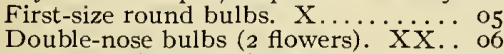

Top roots (3 flowers). XXX....... o7

Glory of Leiden. Long, large yellow trumpet, perianth primrose-yellow. I 5

Glory of Sassenheim. Larger flower and earlier than Victoria; white perianth, yellow trumpet. Top-root

bulbs........................
Golden Spur. Deep yellow perianth
and trumpet; very large; equally good as a forcer and for garden.

First-size round bulbs. $\mathrm{X}$......... 05

Double-nose bulbs (2 flowers). XX. . . o6

Top roots (3 flowers). XXX....... 7

Guernsey-Grown. Can be flowered under glass by January I ........ 07

French-Grown. Can be flowered under glass in December........... ro

Henry Irving. Magnificent flowers of richest yellow; trumpet beautifully frilled....................... of

Horsfieldii. Pure white, with yellow trumpet; very early.

Double-nosed bulbs (2 flowers). XX.. 05

Top roots (3 flowers). XXX........ o6

King Alfred. Golden yellow perianth and trumpet; of beautiful form with deeply frilled mouth; gigantic flower; strong grower; does not force well. Top roots...............

Madame de Graaff. Perianth pure white, trumpet pale primrose.

Top roots...........................
obvallaris. Perianth and trumpet yeilow.

Olympia. Pale yellow perianth, yellow trumpet; as large as King Alfred. Good forcer. Top roots...........

Princeps. Early; sulphur trumpet, white perianth. A popular forcing variety.

Double-nose bulbs (2 flowers). XX. . 04

Top roots ( 2 to 3 flowers). XXX.... 05

Silver Spur. Resembles Empress. The earliest Bicolor variety for forcing.. Io

Sir Watkin. Perianth sulphur, cup yellow, tinted bright orange; large flower.

Double-nosed (2 flowers). XX...... 05

Top roots (3 flowers). XXX....... 06

$\begin{array}{llllll}60 & 4 & 00 & 36 & 00 \\ & & & & & \\ & & & & & \\ 45 & 2 & 75 & 25 & 00 \\ 55 & 3 & 50 & 32 & 00 \\ 65 & 4 & 50 & 40 & 00 \\ & & & & & \\ & & & & & \\ 45 & 2 & 75 & 25 & 00 \\ 55 & 3 & 50 & 32 & 00 \\ 65 & 4 & 50 & 40 & 00 \\ \text { I } & 25 & 8 & 00 & 75 & 00\end{array}$

I $05 \quad 7 \quad 725 \quad 68$ oO

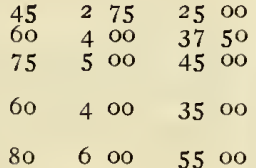

$60 \quad 4$ oo 36 oo

$\begin{array}{lllll}45 & 2 & 75 & 25 & 00\end{array}$

50 $325 \quad 3000$

5 oo 40 oo

I $50 \quad 900$

$45300 \quad 2600$

4 oo 30 oo

$\begin{array}{lllll}30 & 2 & 00 & \text { I } 8 & 00\end{array}$

$40 \quad 250 \quad 2300$

$80 \quad 6$ oo 55 oo

$\begin{array}{lllll}45 & 2 & 75 & 25 & 00\end{array}$
GIANT SINGLE TRUMPET NARCISSI, continued

Trumpet Major. (French-grown.) Each Doz, I00 1,000 Excellent for Christmas forcing; not worth growing for any other purpose.

Van Waveren's Giant. Primrose perianth, bright yellow trumpet; larger than King Alfred and a better forcer. $\begin{array}{lllll}35 & 350 & 25 & 00\end{array}$

Victoria. A fine bicolored trumpet variety. White perianth, yellow trumpet.

First-size, round bulbs. $\mathrm{X}$

Double-nose ( 2 flowers). $\mathrm{XX}$

Top roots (3 flowers). XXX.

VON SION Single. Fine Fine yellow

Trumpets, Mixed. Many varieties...

\section{Double Narcissi, or Daffodils}

Von Sion (True Double Daffodil). Specially Doz. I00 I,000

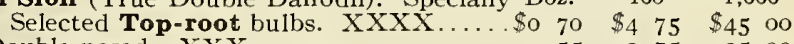
Double-nosed. XXX.

Extra-first-size round bulbs. XX

First-size round bulbs. $\mathrm{X}$.

Alba-plena odorata (Gardenia-flowered Daffodil). Double, snow-white flowers; very

sweet-scented; late flowering. .

Incomparabilis fl.-pl. (Butter and Eggs). Rich yellow and white; double; good forcer or for outside.

Orange Phoenix (Bacon and Eggs). Beautiful white-and-orange Narcissi.

Sulphur or Silver Phoenix (Codlins and Cream). Creamy white, pale sulphur center.

Boddington's “Quality" Double Mixture.

Excellent for bedding or naturalizing.

$\begin{array}{lllll}55 & 3 & 75 & 35 & 00 \\ 45 & 2 & 75 & 25 & 00\end{array}$

$\begin{array}{lllll}35 & 2 & 25 & 20 & 00\end{array}$

$30 \quad$ I 75 I 5 OO

$\begin{array}{lllll}35 & 2 & 25 & 20 & 00\end{array}$

$40 \quad 250 \quad 2200$

$\begin{array}{lllll}45 & 2 & 75 & 25 & 00\end{array}$

25 I 75 I6 00

\section{New Narcissi, Poetaz Hybrids}

Hybrids between $N$. poeticus ornatus and $N$. polyanthus varieties

Perfectly Hardy

Admiration. Sulphur-yellow perianth, sulphur-yellow eye, borAdme dered scarlet. Perhaps the finest all the Poetaz varieties. $30 \mathrm{cts}$. each, $\$ 2.75$ per doz., $\$ 20$ per Ioo.

Alsace. Petals pure white, with yellow eye; when bursting into flower the eye is slightly edged reddish. Broad, large flowers of true Poet form; one of the earliest. Has three flowers on a stem. $7 \mathrm{cts}$. each, 70 cts. per doz., $\$ 5$ per Ioo, $\$ 46$ per I,O0o.

Elvira. Pure white, with yellow eye; large flower of remarkably flowers on a stem. Highly recommended. $5 \mathrm{cts}$. each, $50 \mathrm{cts}$. per doz., \$3.25 per I0o, \$30 per I,000.

Ideal. Perianth white, with dark orange eye; large truss bearing six or seven flowers; beautiful, striking color. Io cts. each, 95 cts. per doz., $\$ 6.5^{\circ}$ per I $00, \$ 60$ per I,000.

Irene. Perianth pure yellow, orange eye. Eight or nine flowers on Irene. a stem. 8c. each, 75c. per doz., $\$ 5.25$ per Ioo, $\$ 50$ per I,O0O. Jaune a Merveille. Perianth yellow, with deep golden yellow Mignonne. White, orange-scarlet cup; four to five flowers on a
stem. 30 cts. each, $\$ 2$ per doz., \$I5 per roo.

\section{ORCHIDS}

The Oncidiums and Odontoglossums are well known to Orchid connoisseurs as a very desirable class embracing a great variety of beautiful forms and colors. They are of easy culture and can be grown in an ordinary greenhouse or conservatory. They may be grown in pots, pans, and orchid baskets, using a potting mixture of fibrous peat and sphagnum moss. Water with caution at first, increasing as growth advances and allow plenty of ventilation in suitable weather. We have just imported, direct from their native habitats in Mexico and Brazil, a stock of epiphytal Orchids in the following three varieties:

Oncidium varicosu m Rogersii. Long branched spikes bearing quantities of large yellow flowers. A very fine Each Doz. Ioo

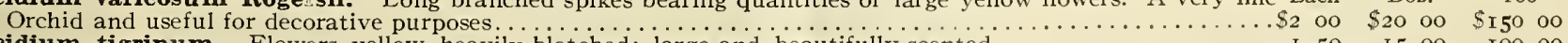

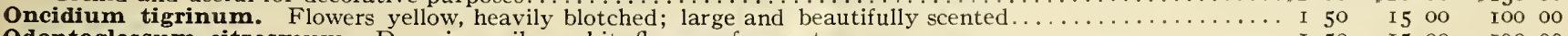
Odontoglossum citrosmum. Drooping spikes; white flowers; fragrant........................... I 50 I 5 oo roo oo 


\section{MISCELLANEOUS BULBS}

The varieties marked with an asterisk $\left(^{*}\right)$ are not hardy, and must not be subjected to frost

ACHIMENES. * Very tender bulbous plant, in variable colors, offer them in ten named varieties. Io cts. each, \$I per doz., \$6 per I 00.

ALLIUM* neapolitanum. An excellent forcer for winterflowering, with immense trusses of Doz. white flowers.

Luteum. Yellow.

Roseum. Pink.

Azureum. Blue.

ANEMONE * Beautiful, quaint, easily grown bulbous plants, but ANEMO little known in American gardens for some unaccountable reason. Plant in October or November, six roots in a 6 -inch pot or bulb-pan, covering them I inch. They may be kept in a cellar or frame protected from frost, until spring, when they may be placed in the greenhouse or window to bloom.

St. Brigid. Beautiful Irish Anemone. Colors from Doz. Iоo maroon and brightest scarlet to flesh-pink and from lilac to purple.......................\$口 $50 \quad \$_{3}$ oo

Blanda. The beautiful, single dark blue Anemone

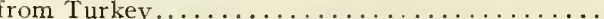

Coronaria, Single Blue. A charming variety . . Single White (The Bride). Pure white.

Single Scarlet. Very brilliant.

Double Ceres. White, shaded with rose

Double Rosetti. Dark pink

Double, King of the Scarlets. Vermilion.

Fulgens. Rich, dazzling scarlet.

Boddington's Choice Double Mixed ...1,000, $\$ 12 \ldots .20$.I 50

CALLA $^{*}$ æthiopica. The well-known white Calla Lily. We offer a fine lot of dry roots, with center shoots ready for forcing. I $3 / 4$ to 2 inches in diameter. 2 to $2 \frac{1}{2}$ inches in diameter.... Each Doz.

$\$ 2000$

The Godfrey. White Calla; free and prolific.

More refined than Ethiopica...

Elliołtiana. Dark golden yellow; large flowers.

Mrs. Roosevelt. Flowers light clear yellow.

$2525^{\circ}$

I5 00

CAMASSIA esculenta (Indian Quamash). Hardy, thriving in Mheltered and partially shaded situations; flowerstalks 2 to 3 feet high and bear twenty or more large blue flowers, each 2 inches across. 20 cts. per doz., \$I.25 per I OO, \$IO per I, 000.

CHIONODOXA (Glory-of-the-Snow). The most beautiful of dwarf, blue, spring flowers.

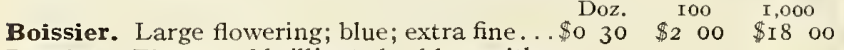
Lucilize. Flowers of brilliant sky-blue, with a

white center.

Sardensis. Deep gentian-blue; very beautiful.

Gigantea. Unusually large flowers of lovely

lilac-blue, with conspicuous white center..

$25 \quad$ I $75 \quad$ I 500

25 I 75 I5 00

25 I 75 I 5 OO

CROWN IMPERIALS (Fritillaria imperialis). Flowers deep shades of orange and reddish buff.

Finest Varieties, Mixed. $20 \mathrm{cts}$. each, $\$ 2$ per doz., \$I 5 per Ioo.

CROCUSES. Crocuses are most effective when massed in beds, borders or in grass terraces or lawns.

Large Blue. Various shades. . Doz. I00 I.000

Large White. Various shades.

Large Striped. Various shades

Large Golden Yellow. Very fine

Large Mixed. All colors.

Albion. Blue, striped white

Baron von Brunow. Dark blue.

Caroline Chisholm. White.

Cloth of Gold. Golden yellow striped maroon .....

Purpurea grandiflora. Top roots

King of the Whites. Largest white; first size.

King of the Whites. Top roots.

Madame Mina. Striped.
CROCUSES, continued Mammoth Golden Yellow. First size. XX. 25 I 50 I2 00 Mammoth Golden Yellow. Top roots.

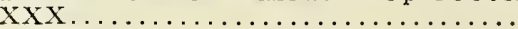

Mont Blanc. Pure white............. Sir Walter Scott. White, lilac-striped.

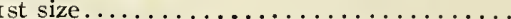
Sir Walter Scott. Top roots............

25 I 75 I 5 00
$\begin{array}{lllll}25 & \text { I } & 75 & \text { I } 5 & 00 \\ 20 & \text { I } & 25 & \text { I } & 00\end{array}$ 20 I 25 I0 00 25 I 50 I 2 oo

ERANTHIS hyemalis (Winter Aconite). The Winter Aconite is the very "firstling" of the year, covering the ground with gilt spangles in the bleakest days of February. Any soil or situation will suit this flower, and it should be planted in large patches within view from the windows. $25 \mathrm{cts}$. per doz., $\$ 1.50$ per IOO, \$I 2 per I,000.

EREMURUS. Majestic, tuberous-rooted plants, with flowerspikes 6 to Io feet high, forming a magnificent column of bloom during June and July. Each Doz.

Himalaicus. Peach-pink.................

Robustus. Delightful rosy pink.............. I 00 I0 00

Bungei. Beautiful golden yellow. One of the scarcest

and most lovely of the Eremurus............ I 50 I5 00

Elwesianus. Soft pink, with bands of deeper color

down the middle of segments............... I 50 I5 00

Collection of one each of above for $\$ 4.50 ; 3$ collections for $\$ 12$

FRITILLARIA Meleagris (Snake's Head, or Guinea Hen Mixture, 40 cts. per doz., $\$ 2.50$ per I oo.

Meleagris alba. Pure white. $5 \mathrm{cts}$. each, $40 \mathrm{cts}$. per doz., $\$ 2.50$ per IOo.

\section{GLADIOLUS COLVILLEI}

\section{Delivery in October and November}

The "Colvillei" section should not be confused with the "Gandavensis," or large-flowering Gladiolus. The Colvillei has much more graceful, slender spikes and daintier flowers, which are very pretty for cutting and arranging in vases with ferns and other foliage.

Ackermanii. Salmon-orange, with white blotches, edged scarlet; very handsome. $25 \mathrm{cts}$. per doz., \$I.50 per Ioo, \$I 2 per I, 0oo.

Blushing Bride. A most beautiful delicate pink Gladiolus for early forcing. $25 \mathrm{cts}$. per doz., $\$$ I.5O per IOO, $\$$ I 2 per I, OoO.

Delicatissima superba. Pure white, large, bright carmine blotch 30 cts. per doz., $\$ 2$ per I00, \$16 per I,000.

Fairy Queen. Carmine-red, white blotch, carmine-bordered. $25 \mathrm{cts}$. per doz., \$I.5O per IOO, \$I 2 per I,000.

Fiery Knight. This is a specially striking and beautiful variety, and we can highly recommend it for all purposes. Dark scarlet, flaked violet-carmine. $55 \mathrm{cts}$. per doz., $\$ 3.5^{\circ}$ per Ioo, $\$ 30$ per $\mathrm{I}, \mathrm{OOO}$.

Fire King. Orange-scarlet, purple blotch, purple-bordered; a beautiful variety. $45 \mathrm{cts}$. per doz., $\$ 2.75$ per I0o, $\$ 25$ per I,000.

Non Plus U1tra (Ramosus type). Large, rosy red, flaked white, shaded magenta. $35 \mathrm{cts}$. per doz., $\$ 2.25$ per I0o, $\$ 20$ per I,000.

Peach Blossom. Lovely soft pink. Resembling the color of the Killarney Rose. $25 \mathrm{cts}$. per doz., \$I.50 per I00, \$I 2 per I, 000.

Pink Perfection. Lilac-rose, white blotch, carmine-bordered. $30 \mathrm{cts}$. per doz., $\$ 2$ per Ioo, $\$$ I 8 per I, 000.

Queen Wilhelmina. Blush-white, with conspicuous blotches of cream, with scarlet margins. $40 \mathrm{cts}$. per doz., $\$ 2.50$ per Ioo, $\$ 20$ per I, ooo.

Sappho. Large; white, shaded pale lilac, with faint, creamy blotches, edged violet. $25 \mathrm{cts}$. per doz., \$I.5O per I Oo, \$I 2 per I, 000.

The Bride (Colvillei alba). This lovely white miniature Gladiolus makes a useful cut-flower for early spring use; will stand forcing. 25 cts. per doz., \$I.50 per I00, \$1 2 per I, 000.

Tristis (grandis). Large creamy white flowers on tall erect stems excellent for cut-flower purposes. $60 \mathrm{cts}$. per doz., $\$ 3.50$ per I00, $\$ 30$ per I, Ooo. 


\section{MISCELLANEOUS BULBS, continued}

\section{DUTCH IRIS (Iris hollandica)}

A race of early large-flowering, bulbous Iris, coming into bloom fully two weeks in advance of Spanish Iris, and in all respects greatly superior. Hardy in the latitude of New York.

Anton Mauve. Soft blue.

C. Van de Windt. Pure white, yellow blotch.

David Teniers. Lavender, falls Hart $N$

Hobbema. White, yellow falls. J. Weissenbruch. Pale mauve. Rembrandt. Deep blue, orange blotch.

Price of the above, 75 cts. per doz., $\$ 5$ per $100, \$ 45$ per 1,000 Mixed Dutch Iris, 65 cts. per doz., $\$ 4.25$ per $100, \$ 40$ per 1,000

\section{ENGLISH IRIS (Iris anglica)}

The flowers are nearly as large as those of the Japanese Iris. They grow from 18 to 20 inches high and are perfectly hardy. They flower after the German Iris and before the Japanese.

Argus. Pink and white.

Bleu Celeste. Sky-blue.

Couleur Cardinal. Dark velvety blue.

Duke of Richmond. Magenta.

Mont Blanc. Pure white.

\section{Othello. Magenta-purple.}

Thackeray. Rich claret-color.

Tricolor. White, blue and red.

Washington. Pale lavender, mottled blue.

Bleu Mourant. Blue and white.

Price of the above

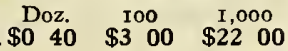

Splendid Mixture. $\begin{array}{lllll}25 & 1 & 75 & 15 & 00\end{array}$

\section{SPANISH IRIS (Iris hispanica)}

\section{(TOP ROOTS)}

Adapted for forcing for Easter blooming and for massing in beds for June flowering, or for colonizing in the herbaceous border.

Belle Chinoise. Pure yellow. King of the Blues. Finest blue.

British Queen. Large; white; La Grandesse. The best and very fine.

Cajanus. Deep golden yellow.

Chrysolora. Pale yellow.

Czar Peter. Porcelain - blue;

purest white.

Louise. Pale blue, slightly spotted; fine flower.

Queen Emma. Deep golden

Snowball. Very large; white.

extra fine.

Darling. Blue; very fine; early. Snowball. Very large; white.
Queen Wilhelmina. White, yellow blotch. Doz. Ioo t,ooo

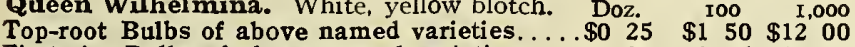

First-size Bulbs of above named varieties...... 20 . $125 \quad \begin{array}{llll}25 & 10 & 00\end{array}$

Boddington's Choicest Mixed, all colors...... 15 1 007750

\section{FORCING IRISES OF SPECIAL MERIT}

Filifolia. French-grown bulbs. Deep blue. Can be Doz. ${ }_{100}$ forced into bloom by January I..............\$I oo $\$ 5$ oo

Filifolia. Dutch-grown bulbs. Can be flowered under

glass in March......................... $30 \quad 2$ oo

Histrioides. Large, bright blue flowers, dark spots $\cdots 3$ on 20 oo

Pavonia (Peacock Iris). Pure white, with a bright blue

spot on each petal. Fine for pot or garden culture.

Susiana (Mourning Iris). Silvery gray, mottled and

50 350

veined with dark chocolate and black... Each, I 5 c. .

Tingitana. French-grown. Dark blue with yellow. Can be flowered January I... .

\section{0}

IXIAS.* The Ixia is a beautiful, tender, little, winter-flowering colors are rich and varied.

Magnificent Named Varieties, in I2 fine sorts. $20 \mathrm{cts}$. per doz., $\$ \mathrm{I} .25$ per IOO, \$10 per I, 000.

Fine Mixed Varieties. I 5 cts. per doz., $\$ 1$ per Ioo, $\$ 6$ per I,ooo.

OXALIS.* Lovely little bulbous plants for hanging-pots and saskets. The bulbs should be planted an inch deep. six to eight in a 5 -inch pot. They need a sunny situation.

Bermuda Buttercup. Deep yellow; extra-large bulbs. \$o 30 Bowiei. Rosy crimson; fine flower.

Grand Duchess. White.

Grand Duchess. Pink.

Grand Duchess. Lavender.

Lutea, Single. Yellow

Lutea, Double. Yellow

Rosea. Rose..............

Versicolor. Crimson and white

Mixed, All Colors.
ORNITHOGALUM* arabicum (Star of Bethlehem). Of the easiest culture, throwing up a tall spike bearing numerous large, milk-white, star-shaped flowers, with a black center, and having a distinct aromatic perfume. $7 \mathrm{cts}$. each, $60 \mathrm{cts}$. per doz., $\$ 3.50$ per 100 , $\$ 30$ per 1,000 .

Umbellatum. Perfectly hardy; the American Star of Bethlehem; flowers white and star-shaped; fine for naturalizing. $20 \mathrm{cts}$. per doz., $\$ 1.50$ per IOO, \$I2 per I,000.

\section{LILY-OF-THE-VALLEY}

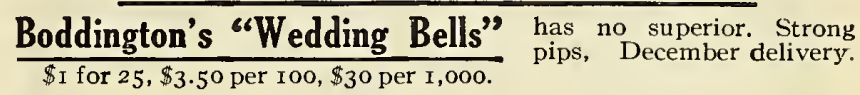

\section{Lily-of-the-Valley Pips from Cold Storage}

$\$ 5$ per roo, $\$ 45$ per $\mathrm{I}, 000$.

RANUNCULUS* Boddington's Giant. Gorgeous double blooming, or in coldframes for spring. Same culture as for anemones, which see. Giant French. Mixed colors............ \$0 II $\$$ II Giant Persian. Mixed colors.............. I5 I Giant Turban. Mixed colors.............. I5 I

SPARAXIS * Tender, bearing beautiful flowers about 2 inches in the across, on long, graceful spikes. Should be grown in the conservatory or house in pots, or in coldframes. They flower during the winter and spring months.

10 Choice Named Varieties. $20 \mathrm{cts}$. per doz., \$1.50 per Ioo.

Choice Mixed Colors. I5 cts. per doz., \$I per 100.

SCILLA præcox (sibirica). (The Blue Squill.) Perfectly in conjunction with snowdrops. Mammoth bulbs, $20 \mathrm{cts}$. per doz., $\$ 1.50$ per I00, \$12 per 1,000 .

Campanulata (Bell-flowered Squill). Rosy purple color. Good for acclimatizing or planting among herbaceous plants. 20 cts. per doz., \$1.25 per Ioo, \$10 per I,000.

Nutans cærulea. The English Blue Bell. Fine for acclimatizing. 20 cts. per doz., $\$ 1.25$ per 100, $\$$ Io per 1,000 .

\section{SPIRAEA, or ASTILBE}

\section{November Delivery}

Spiræas make excellent plants for Easter and Memorial Day decorations. They should be potted on arrival and be kept in a cellar or coldframe till about two months before they are needed in flower.

AMERICA. Elegant flowers of lilac-rose, with Each Doz. Ioo

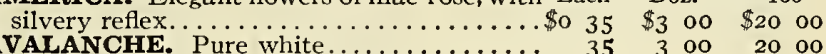

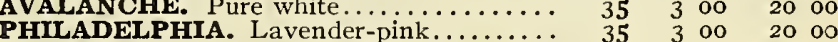
RUBENS. The darkest of all the pink va- $\begin{array}{llll} & \\ \text { rieties. very large. } & \end{array}$

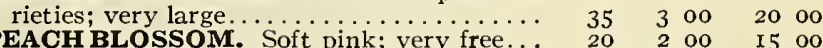
$\begin{array}{llllll}\text { PEACH BLOSSOM. Soft pink; very free... } & 20 & 2 & \text { oo } & \text { I5 } & 00 \\ \text { QUEEN ALEXANDRA. Shell-pink........ } & 25 & 2 & 50 & \text { I5 } & 00\end{array}$ Astilboides floribunda. Pure white........... $25 \quad 25 \quad 2 \quad 50$ I5 00 Compacta multifiora. White.............. 25 25 250 I5 oo Gladstone. Enormous spikes; pure white... 25 25 250 I 5 oo Japonica. The old white variety. 20 I 50 I 200 Queen of Holland. Early bloomer; white... $25 \quad 250$ Palmata rosea. The beautiful deep pink hardy Spiræa.

Aruncus. The wonderful hardy white Spiræa....

$\begin{array}{lllll}25 & 2 & 50 & \text { I } 5 & 00\end{array}$ $25 \quad 250 \quad$ I 5 oO

SNOWDROPS (Galanthus). Among the hardiest and earliest 2 inches deep. They thrive in almost any soil and situation and are fine for naturalizing. Doz. I00 $t, 000$ Large Single. First size. X ............

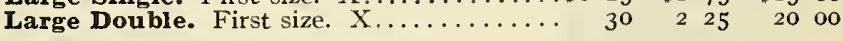

TRILLIUM grandiflorum (American Wood-Lily). Perfectly RILLIUM hardy, growing and flowering profusely in partially shaded nooks about the lawn, under trees, etc. The flowers are large, of the finest white, changing in a few days to soft rose. Io cts. each, \$I per doz., $\$ 7.5^{\circ}$ per Ioo.

Erectum. The Purple Wood-Lily, the earliest to flower. I5 cts. each, \$1.25 per doz., \$9 per Ioo.

TRITELEIA uniflora (Spring Star Flower). 15 cts. per doz., 


\section{INSECTICIDES, FUNGICIDES, ETC.}

Ant Exterminator. Will destroy or drive away black ants from lawns, trees, plants, houses or other affected locality. Per lb. tin, $80 \mathrm{cts}$.

Aphine. Kills plant-sucking insects, such as green, black or white fly, red spider, thrip, mealy bug, brown and white scale. Used as a spray or wash, as dirceted on each can. An excellent cleaner for house plants. I/2pt. 40 cts., pt. 65 cts., qt. $\$ I$, gal. $\$ 2.50$.

Aphis Punk. For use in greenhouses only. A paper that has been thoroughly saturated with nicotine. Uscd for fumigating, giving off dense fumes of nicotine. For destroying aphis, thrip, white and green $\mathrm{fly}$, also red spider. Pkg. $60 \mathrm{cts}$., $\$ 7$ for $\mathrm{I} 2 \mathrm{pkgs}$.

Arsenate of Lead, Powdered. Better than Paris Green. Does not burn foliage. Has all advantages of arsenate of lead paste, but goes twice as far, and is easier to handle. Dilutes I lb. to 5o gallons. $1 / 2 \mathrm{lb} .30 \mathrm{cts} ., 1 \mathrm{~b} .45 \mathrm{cts} ., 6 \mathrm{lbs} . \$ 2.50$.

Arsenate of Lead, Paste. For spraying. Effective against all leafeating insects. Lb. $30 \mathrm{cts} ., 5 \mathrm{lbs}$. and over at $25 \mathrm{cts}$. per lb. I 00 lbs. $\$ 20$.

Asbestos Torches. For destroying caterpillars' nests on branches of trees. 75 cts. each; with pole, 30 cts. extra.

Black-Leaf 40. A concentrated solution of nicotine sulphate; an excellent spray for black aphides and sucking insects of all kinds. Dilutes one part to 900 or $I, 000$ parts of water, according to treatment. Full directions on cach package. I-oz. bottle 25 cts., I 2 -lb. tin 75 cts., 2 lbs. $\$ 2.50$, Io lbs. \$1 0.75 .

Bordeaux Mixture, Dry. The standard remedy for all fungoid diseases of plants. I-lb. box, 35 cts., 5 lbs. $\$ 1.50,25 \mathrm{lbs}$. and over at 25 cts. per lb.

Bordeaux Mixture, Paste. For all fungoid diseases, such as mildew and various rots of grapes, etc. Pt. $25 \mathrm{cts}$., qt. $45 \mathrm{cts}$., gal. \$I.25 5 gals. $\$ 5$

Climax Lawn Sand. Kills every weed that grows on grass lawns and also improves the grass. Full instructions for using with all packages. $31 / 2-1 b$. tin can 60 cts., $7-1 b$, tin can $\$ I, 14-1 b$, tin can $\$ 1.75,28-\mathrm{lb}$. $\operatorname{keg} \$ 3,56-\mathrm{lb}$. keg $\$ 5.50$.

Copper Solution, Ammoniated. A valuable fungicide, giving better results than bordeaux in the autumn. One quart of solution to twcnty-five quarts of water. Ot. $\$ \mathrm{I}$, gal. $\$ 2.50$.

Cutworm Food (Warncke's). The best exterminator of cutworms. Directions on package. 5 lbs. $85 \mathrm{cts}$., Io lbs. \$I.35, I oo lbs. $\$ 8.50$.

Fir-Tree-Oil Soap, Stott's. 1/2-1b. can $30 \mathrm{cts.}, 2-1 \mathrm{~b}$. can $85 \mathrm{cts}$.

Fish-Oil Soap. For mild forms of scale, and is an exccllent summer spray, when something stronger cannot be used, where the San José scale exists. Lb. $20 \mathrm{cts} ., 3-1 \mathrm{~b}$. box $55 \mathrm{cts}$., 25 lbs. $\$ 3.75$, 1 oo lbs. $\$ 12.50$.

Flowers of Sulphur. A specific against mildew in the greenhouse. Lb. Io cts., Io lbs. $75 \mathrm{cts} ., 25 \mathrm{lbs}$. and over at $6 \mathrm{cts}$. per lb.

Fungine. An infallible remedy for mildew, rust, wilt and other fungous blights affecting flowers, fruits, etc. $1 / 2$ pt. 40 cts., pt. 65 cts., qt. \$I, gal. $\$ 3.50$.

Grape Dust. Mildew Remedy. 5-1b. pkg. 60 cts., Ioo-lb. keg \$o.

Hellebore Powder. A remedy against currant and cabbage worms, etc. I-lb. box $75 \mathrm{cts}, 2-1 \mathrm{~b}$. box $\$ \mathrm{I} .25$.

\section{SPRAYERS, VAPORIZERS AND}

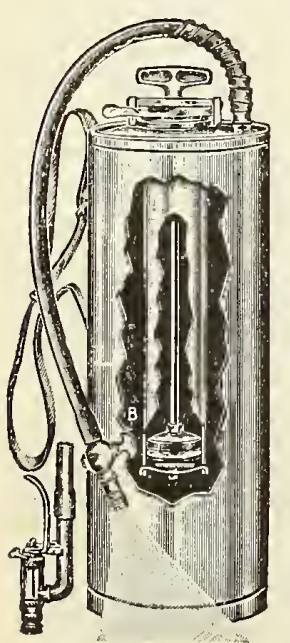

Auto-Spray
Auto-Spray. For spraying insecticides, fungicides, whitewash, etc. When properly charged, holds three gallons of solution and one gallon of compressed air. The "Auto-Pop" Nozzle cannot clog. No continuous pumping; twelve strokes of the plunger will compress the air, and two pumpings will cmpty the entire contents. It works entirely autoniatically from six to fifteen minutes, according to the nozzle opening.

Auto-Spray, No. 1. B. Brass tank, with "Auto-Pop" Nozzlc... . . . . . . Auto-Spray, No. 1 D. Galvanized tank, "Auto-Pop" Nozzle.

\section{EXTRA ATTACHMENTS}

Brass Strainer, necessary for the proper preparation of solutions.

BRASS ELBOw for spraying the under side of foliage. .

Extension Pipes. Brass, 2-foot lengths; as many as three can be used for reaching trees. Each length...

Herbicide. A liquid weed-killer. One gallon diluted with forty gal ons of water will thoroughly clean I,00o square feet of ground of all weeds. 2-gal. $\$ 3.25,5-$ gal. keg $\$ 6.5^{\circ}$, I o-gal. keg, $\$ 12$.

Imp Soap Spray. Peculiarly effective against red spider, on fruit, etc., rose bug, white, black and green fly, mealy bug, thrip, aphis, and other insect pests. Qt. $55 \mathrm{cts} .$, gal. $\$ \mathrm{I} .65,5$ gals. $\$ 7.5^{0}$.

Kerosene Emulsion. Effective against cabbage worms, caterpillars, soft scale on trees. Qt. 50 cts., gal. $\$ 1.25,5$ gals. $\$ 5.50$.

Lemon Oil. Effective against aphis and all plant-sucking insects. Pt. 50 cts., qt. 90 cts., 1 $/ 2$ gal. $\$$ I.50, gal. $\$ 2.50,5$ gals. $\$$ I 0.50 .

Nico-Fume. A nicotine saturated paper for greenhouse fumigating, used also for tying beneath chrysanthemum blooms in the autumn to discourage insect pests. Packed in tins. 24 sheets, 85 cts.; 144 sheets, $\$ 4 ; 288$ sheets, $\$ 7.50$.

Nico-Fume, Liquid. An excellent tobacco extract for spraying or vaporizing in greenhouses. Lb. \$1.50, 4 lbs. $\$ 5.50,8 \mathrm{lbs}$. \$10.50.

Nicoticide. Used as a spray for aphis, but chiefly for vaporizing in greenhouses. 1/4 pt. 70 cts., I/2pt. \$I.25. Pt., sufficient for 32,000 cubic feet, $\$ 2.50$; gal. \$I 5 .

Nikoteen. For vaporizing in greenhouses against insect pests. Lb. bottle \$I.50, Io 1bs. \$I

Paris Green. For the destruction of potato bugs. Lb. 50 cts., 5 lbs. \$2.25.

Pyrox. The best and safest all-round spray for all insects, blights and fungus troubles. Kills potato bugs. Sticks like paint. I $1 \mathrm{~b} .35 \mathrm{cts}$., 5 lbs. $\$ 1.25$, Io lbs. $\$ 2.25,25$ lbs. $\$ 5.50$

Readeana. Rose bug exterminator, kills all insects which infest trees and plants, cspecially useful on roses and chrysanthemums. 24 -oz. bottle $\$ 1$, I gal. $\$ 4,5$ gals. and over at $\$ 3.50$ per gal.

Slug-Shot. The standard rcmedy for currant worms, rose bugs, cabbage worms, and almost any soft-shelled insects that infest the vegetable- or flower-garden. 5 lbs. $50 \mathrm{c}$, Io lbs. $90 \mathrm{c}$., I $251 \mathrm{bs}$. $\$_{\text {I I }}$.

Sodium Cyanide. Used in conjunction with sulphuric acid to produce hydrocyanic acid gas. Death to all animal and insect life. Great care must be exercised in its use. $\$ 1.5^{\circ}$ per lb.

Tobacco Dust. The burning or dusting kind. 5 lbs. will fumigate a house roo by 25 feet. Put up in Ioo-lb. bags for $\$ 4$.

Tobacco Stems. I o0-1b. bale $\$ 2,300$ lbs. $\$ 5$.

Tree Tanglefoot. A paste preparation for painting around the trunks of trees, in the form of a band; insects and other crawling pests cannot get over it. $3-\mathrm{lb}$. can $\$ 1.25$, I $0-1 \mathrm{lb}$. can $\$ 4,40-1 \mathrm{~b}$. can $\$ 14$.

Weed Killer, Key Brand. Quart can, will make six gallons of liquid, $60 \mathrm{cts}$; gallon can, will make forty gallons of liquid, $\$ 1.50$.

X-L-All Liquid Insecticide. English preparation for spraying; harmless to very delicate plants; kills inealy bug, red spider, and all insect pests. Qt. $\$ 1.25,1 / 2 \mathrm{gal} . \$ 2.25$, gal. $\$ 4.25$.

X-L-All Vaporizing Compound. Claimed to be the most easy, effectual and cheapest method of fumigating greenhouses and frames. In liquid and dry-cake form, box of 80 cakes for \$I0.50, I 5 cts. per cake. Each cake sufficient for I, ooo cubic feet.

No. I. \$8.00 bottle contains sufficient for 40,000 cubic feet of spacc No. 2. $\$ 4.50$

No. $3 . \$ 2.50$

No. $4 . \$ 1.50$

\section{BELLOWS FOR APPLYING INSECTICIDES,}

Auto-Spray No. 25 A. One quart, all tin. 9oc. each. Auto-Spray No. 25 B. One quart, tin pump, galvanized tank. \$I each.

Auto-Spray No. 25 C. One quart, tin pump, brass tank. \$I.25 each.

Auto-Spray No. 5. Double acting (making a continuous spray). $\$ 5$ each.

Alpha Hand Sprayer. The premier English compressed-air Hand Sprayer. Makes a beautiful, fine spray which covers a large area. Adapted for spraying under foliage; works automatically. Sold in two sizes: No. 3 (holds 4 qts.), \$1 o.75 each; No. IA (holds 2 qts.), \$9 each.

Sprayer, Muratori's Hand. Invaluable for spraying orchids and other plants hanging from the rafters of Hand Sprayer a greenhouse; especially adapted for ladies' use. Works automatically by compressed air. \$I2.

Vaporizer, Campbell's Sulphur. No. I, $\$ 6$ each; No. $2, \$ 7.50$ each. GLASS BA Lls, per box of 6 , I 5 cts. Yellow Powder, per tiil, $20 \mathrm{cts}$. Hollow or SOLID WICKS, is cts. each.

Vaporizer for Tobacco Extracts.

......\$o 75

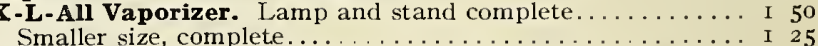

Bellows, Powder, Woodason's. Single-cone, small sizc ...... I I 25 Single-cone, large size . . . . . . . . . . . . . . . . . 225

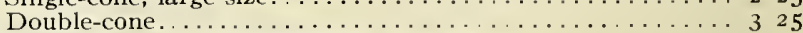

Bellows, Liquid, woodason's. Small size............. I $5^{0}$

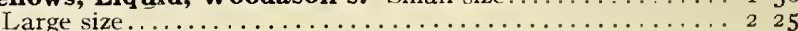


We Deliver all Seeds and Bulbs free anywhere in the states east of the Mississippi Riv. er, if your purchase amounts to One Dollar or over, and cash accompanies the order.$$
=
$$

This applies to

Seeds and Bulbs Only

P. 0

County

State

Name

Street Address
ORDER SHEET

\section{ARTHUR T. BODDINGTON CO., Inc. SEEDSMEN}

128 Chambers Street, New York City

Name of Gardener (if any)
Customers Please do NOT Write in Here R.

O. N.

Stameps

Cash.

Checks

M. Order

Cr. Memo

Fl. Seed

...Veg. S

Bulis.............Grass $\mathrm{S}$

Sundries......... Roses

Plants.

Camras

Fertz

Amount Enclosed \$ Express Office If different

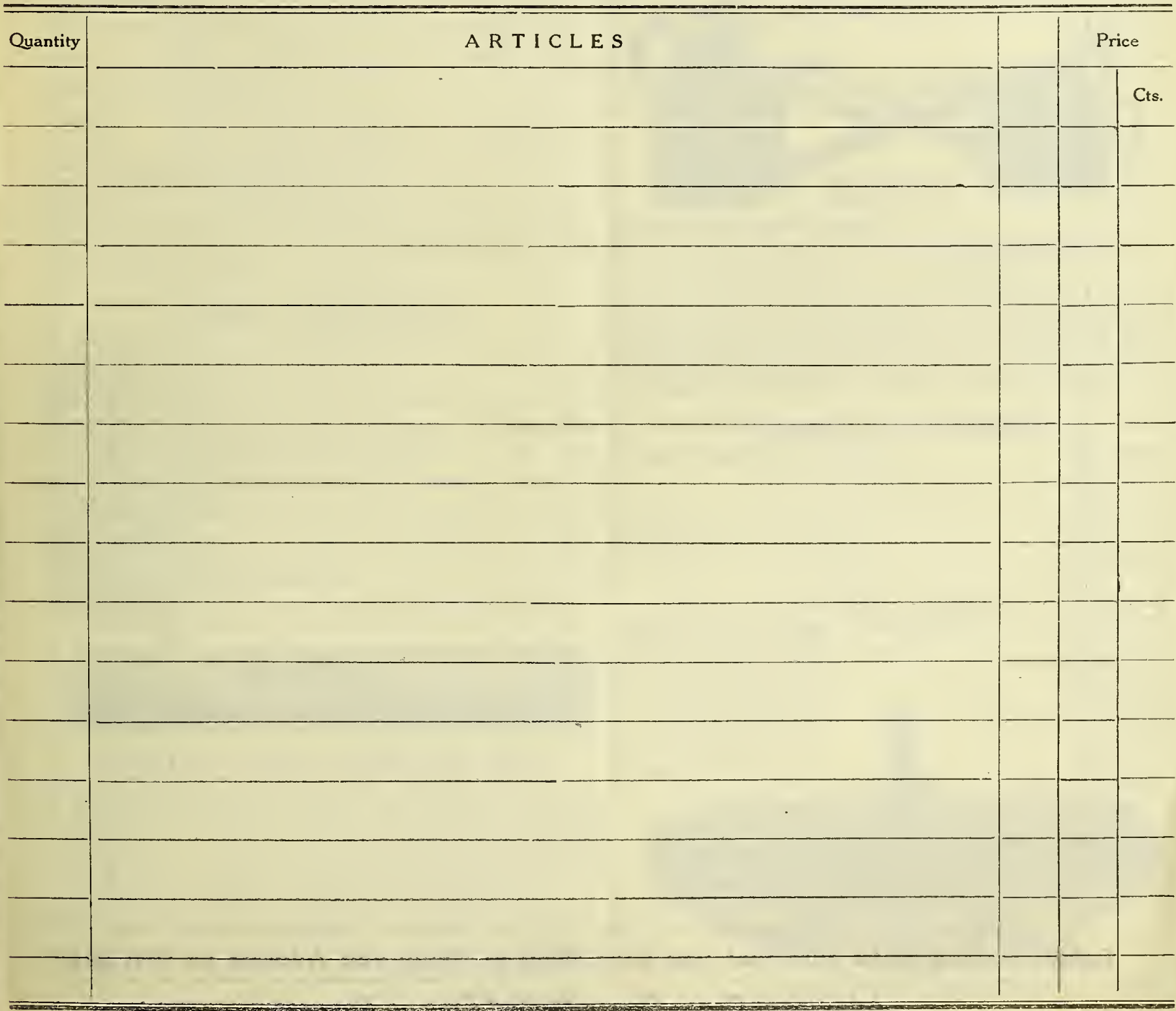




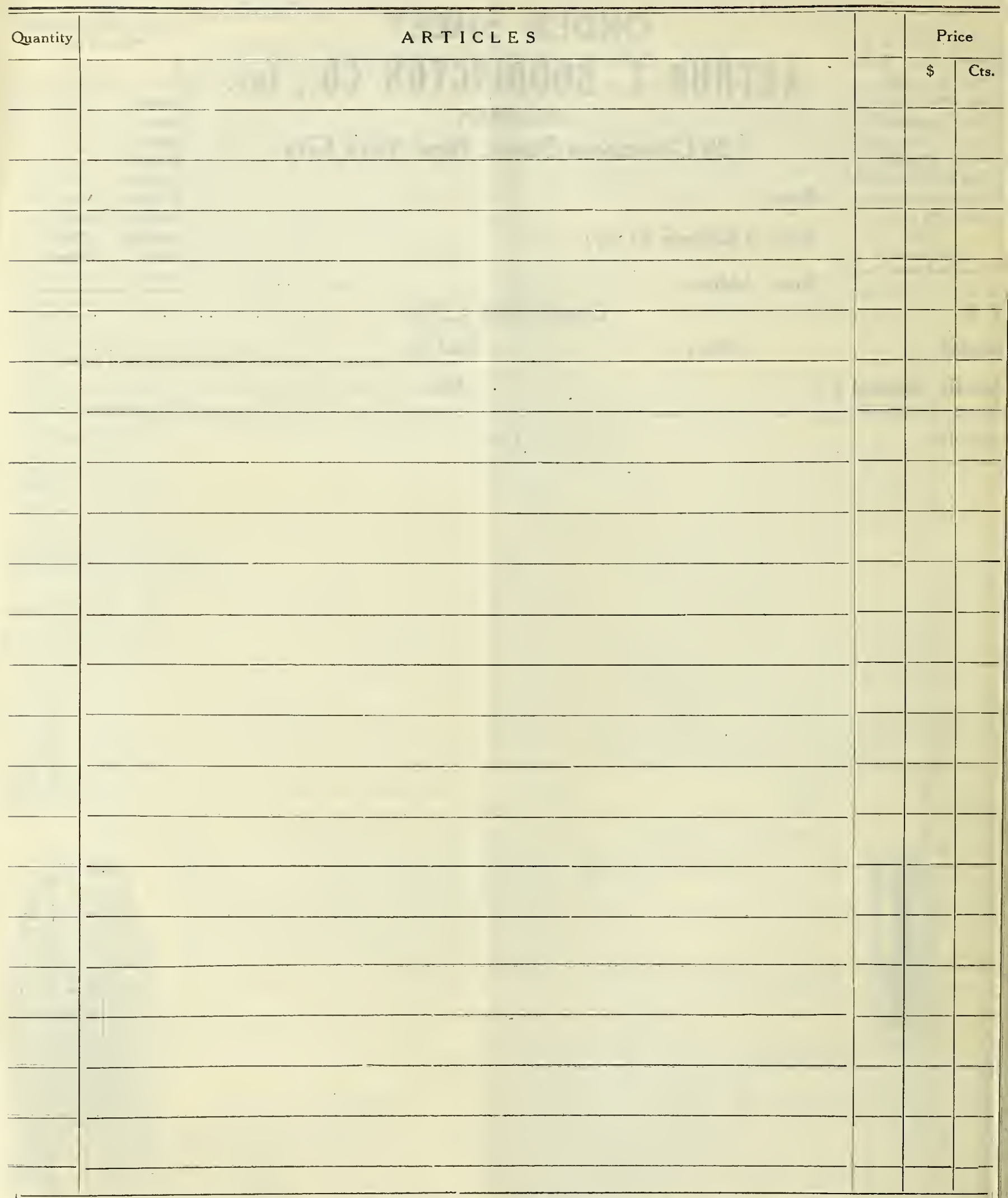

Before mailing make sure that you have filled in Name and Address on first page Additional Order Sheets Mailed Free on Request 


\section{STAKES AND PLANT SUPPORTS}

Bamboo Canes, Chinese. These are the genuine Chinese stakes, being very strong and heavy.

\begin{tabular}{r|r|rrr}
100 & 1,000 & 6 feet, heavy..... $\$ 225 \quad \$ 20$ o0
\end{tabular}

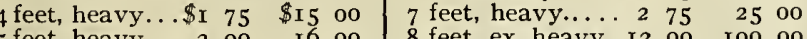
5 feet, heavy... 2 oo I6 oo 8 feet, ex. heavy 12 oo roo oo attractive, strong and extremely inexpensive. Just the thing for hyacinths, freesias, lilies, etc.

Painted Green

I 2 inches..... $\$ 0 \quad 40 \quad \begin{array}{ll}\mathrm{I}, 000 \\ 300\end{array}$

I 8 inches...... $45 \quad 350$

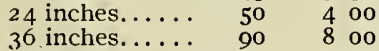

$\begin{array}{ll}36 \text { inches....... } & 90 \\ 42 \text { inches..... } & 95\end{array}$

95900

48 inches...... $\$ 1$ 100 60 inches.......... I 25 II 25

5 to 6 feet....... 90

6 feet.......... I r oo 8 oo

列 ing to $I$ inch, $\$ 1.75$ per doz.

Carnation Supports, Model Extension-

Two-ring. . . .

Doz. $\quad$ 100 Three-ring.

Dahlia Poles, or Heavy Stakes. No. 22 . Round, painted green, with long, tapered end; very strong.

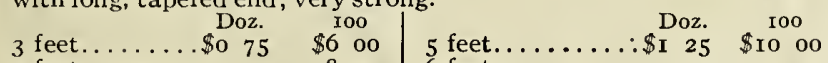
4 feet........ I oo 8 o0 6 feet.......... I 50 I2 Stakes for Plants, Light. Round, painted green, tapering.

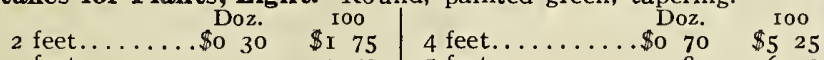
3 feet........ $50 \quad 350$ feet........ $80 \quad 600$

Stakes, Galvanized Wire. No. 8 wire.

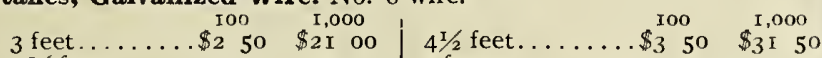
$31 / 2$ feet....... 3 oo 24 oo 5 feet......... $3375 \quad 35$ oo 4 feet....... $325 \quad 2750$ 6 feet........ 5 oo 42 oo

'romato Supports, New Model. (Wire.) Three rings, three legs. $45 \mathrm{cts}$. each, $\$ 4.5^{\circ}$ per doz., $\$ 33$ per roo.

Model. (Wire.) Two rings, three legs, $20 \mathrm{cts}$. each, \$2 per doz., $\$ 15$ per 100.

Lever Clip, Blake's. For fastening rose and chrysanthemum wire stakes. A labor-saving device. Blake's Lever Clip is the "tie that binds." It binds the wire to the stakes. 90 cts. per box (500 to the box), \$1.50 per 1,000 .

\section{TYING MATERIALS}

Raffia, White. $25 \mathrm{cts}$. per lb., $90 \mathrm{cts}$. for $5 \mathrm{lbs}$., $\$ \mathrm{r} .50$ for $10 \mathrm{lbs}$. Extra long, fresh and heavy, $35 \mathrm{cts}$. per lb., $\$$ I. 50 for 5 lbs., $\$ 2.75$ for ro lbs.

Raffia, Green. \$I per 1b., \$9.50 for Io lbs.

Silkaline. For stringing smilax, etc. Fast green colors; will not fade

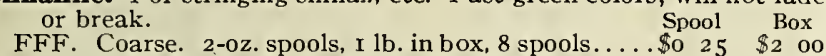
FF. Medium. 2-oz. spools, I lb. in box, 8 spools....... $25 \quad 250$ F. Fine. 2-oz. spools, $\mathrm{I}$ lb. in box, 8 spools........... 252 oo

Twine, Soft. For tying vines, etc., very strong. 3 - and 5-ply. Large balls, $35 \mathrm{cts}$.

Tarred Yarn. Excellent, low-priced material for raspberries, shrubs, etc. Lb. 50 cts.

Tarred Marline. Of better quality than the above; twisted in strands. In 5-lb. balls. Lb. \$I.

Wire, Bouquet, Florists' Annealed. Nos. 22, 23 and 24, in coils of 12 lbs. \$1.50 per coil.

Florists' Bright. Cut in lengths. In boxes of $\mathrm{r} 2 \mathrm{lbs}$. (one stone). 12 in. and 18 in. long. No. 22 Wire, $\$ 1.50 ;$ No. 24 , Wire, $\$$ I.75.

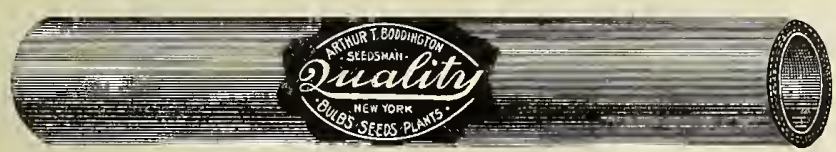

\section{RUBBER HOSE, NOZZLES, ETC.}

Boddington's Quality Non-Kinkable. Made of pure rubber by a special process, does not crack or scale, and will not kink. We can supply in any length if advised at time of ordering. Guaranteed for one year, $3 / 4$-inch, $\$ 6.50$ for 25 feet, $\$ 12$ for 50 feet, $\$ 22$ per Iooft.

The Revero is a model, indestructible Hose for the lawn, greenhouse, stable and garage. Cut any length desired and fitted with couplings. $3 / 4$-inch, 22 cts. per foot; $1 / 2$-inch, I 8 cts. per foot.

Hose Menders, Cooper's. 3/4-inch, Io cts. each, \$I per doz.

Kinney Pump. For distributing water and manure through the hose at the same time. $\$ 2.50$ each.

Siamese Attachment. This brass hose attachment is fitted with a swivel coupling, and is an excellent arrangement for operating from one faucet two or more lawn sprinklers at a time. Can be attached to hose and sprinklers very easily. $3 / 4$-inch, $\$ 1.25$ each.
Boston Graduating Nozzle. Throws a coarse or fine spray, or a solid stream. $3 / 4$-inch, $60 \mathrm{cts}$. each.

Boston Rose Hose Sprinkler. A wide-face Nozzle, like the rose of a watering pot. 3 -inch face, $\$ 1$ each; 4 -inch face, $\$ 1.25$ each.

Schubert's Sprinkler. Can be used for either watering or syringing; especially recommended for greenhouse purposes. \$1.50 each.

Stott Sprayer. A favorite with rose-growers; throws a fine, misty spray with great force, thus exterminating red spider. Singlespray type, $\$ 1.25$ each; double-spray type, \$1.75 each.

\section{LAWN SPRINKLERS, ETC.}

"Ring." Made of heavy brass, 8 inches in diameter. Easily moved over the lawn without turning off the water. \$I each.

"The Turbine." Will spray over a diameter of I 5 feet; simple and effective. \$2 each.

Eureka No. 55B. The Eureka Sprinkler will revolve under extremely low pressure, and is a first-rate article. The head, arms and upper stem are nickel-plated brass and all bearing parts of the Eureka are of brass. The japanned black and has a loose swivel. Height ro inches. \$1.50. "Putting-Green." A two-arm Sprinkler, standing 4 feet high, on a large, malleable-iron base, ro inches across, so that it will not injure

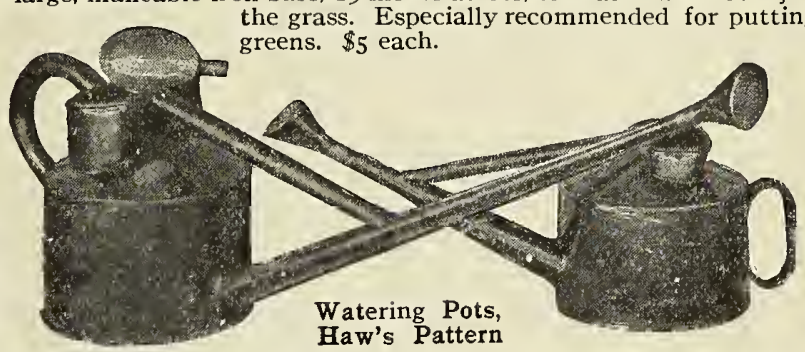

Watering Pots, Haw's Pattern-

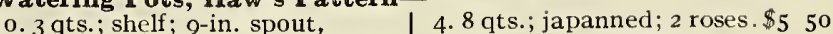
I pot rose and extra joint. $\$ 3$

I. 3 qts.; japanned; 2 roses 4 oo

2. 4 qts.; japanned; 2 roses 425

5. ro qts.; japanned; $r$ rose

and spreader..........6 60

6. 12 qts.; japanned; $I$ rose and spreader.

725

Watering Pots, "The Philadelphia." With brass joints and two copper-faced roscs. 6-qt. $\$ 2.50,8$-qt. $\$ 2.75$, ro-qt. $\$ 3.75$, r 2 -qt. $\$ 4$.

Watering Pots, French. Brass handles and joints, two copperfaced roses, coarse and fine. 6-qt. $\$ 2.75,8$-qt. $\$ 3$, Io-qt. $\$ 3.25$.

Watering Pots, Strawberry or Shelf. Galvanized; holds 3 qts., \$ I.50.

\section{VARIOUS SUNDRIES}

Labels, Wooden, Pot or Garden-

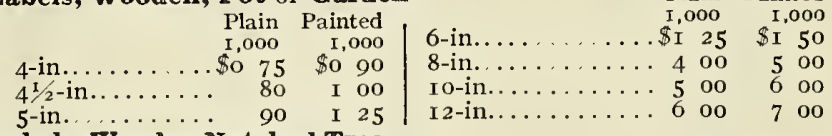

Plain Painted

Labels, Wooden Notched Tree-

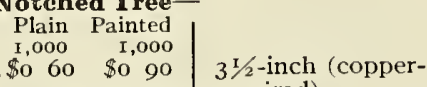

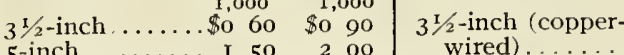

5 -inch......... I $50 \quad 2$ oo wired) ....... \$I $80 \quad \$ 2 \quad 50$

Pencils, Garden, Wolf's Indelible Black. For wooden labels. Io cts. each, \$r per doz.

Baskets, Imported English Garden.

No. 2 , size $1 \mathrm{I} 1 / 2 \times 6$ in $\ldots$

\$ach Doz.

No. 4 , size $15 \times 8 \frac{1}{2}$ in..

No. 5 , size $17 \mathrm{I} / 2 \times 9 \mathrm{l} / 2 \mathrm{in}$.

No. 6 , size $201 / 2 \times 10^{1 / 2}$ in.

No. 8 , size $26 \times 14$ in.

No. 9 , size $28 \times 15$ in.

80900

$\begin{array}{llll}1 & 00 & 10 & 50 \\ 1 & 20 & 12 & 50\end{array}$

I 50 1 17 o0

2 o0 2100

$\begin{array}{llll}2 & 25 & 23 & 00\end{array}$

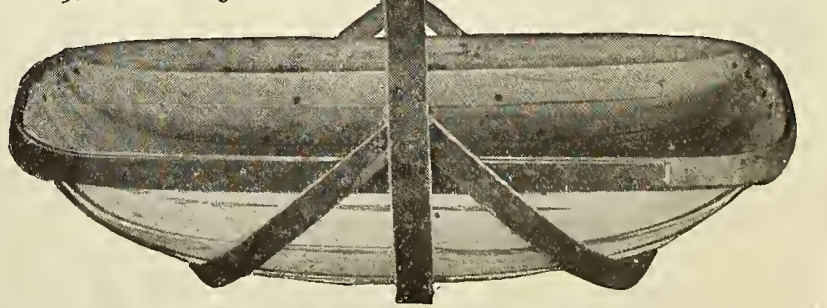

Imported English Garden Basket 
VARIOUS SUNDRIES, continued

Baskets, Wire, Hanging.

8-inch diam.

Io-inch diam.

I 2-inch diam.

Each Doz.

$\begin{array}{rrr}50 & \$ 5 & 00 \\ 60 & 6 & 00\end{array}$

Blinds, Split Bamboo. Fitted greenhouses, or for porches and verandas. 5, 6, 8, io and I 2 feet wide, all 8 feet long in the drop. Stained slats, $1 / 4$ inch wide, $\$ 4$ per I oo square feet; $1 / 2$ inch wide, $\$ 5$ per I oo square feet Painted slats, $1 / 4$ inch wide, $\$ 8$ per Ioo square feet; $1 / 2$ inch wide, \$I per I oo square feet.

Intermediate sizes of above made to order. Price on application.

Boxes, Flower, Cardboard. Order by number.

No. $41 / 2 \ldots \ldots 23 / 4$ inches.... I6 inches.... 4 inches.......\$3 oo

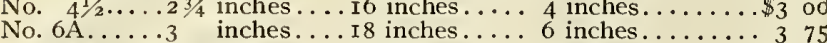

No. I $2 \mathrm{~A} \ldots .6$ inches...26 inches.... I6 inches........ I 2 oo

No. $23 \ldots \ldots 5$ inches....30 inches.... 8 inches........ Io oo

Boxes, Corrugated Cardboard. For shipping. Very strong and reinforced. Shipped flat.

No. A. $20 \times 7 \times 4$ inches.

No. B. $28 \times 8 \times 5$ inches.

No. C. $30 \times 12 \times 6$ inches.

No. D. $36 \times 14 \times 8$ inches

No. E. $42 \times 13 \times 6$ inches.

No. F. $48 \times$ I $8 \times 8$ inches
Boxes, Leatheroid, for Shipping Cut-Flowers. Very strong.

Doz.
$\$ 2$ OO $\$ 13$ oO

$\begin{array}{rrrr}2 & 50 & \text { I } 8 & 00\end{array}$

$\begin{array}{llll}2 & 50 & \text { I } 8 & 00 \\ 3 & 00 & 23 & 00\end{array}$

$\begin{array}{llll}4 & 25 & 3 \text { I } & \text { OO }\end{array}$

$\begin{array}{llll}4 & 75 & 34 & 00\end{array}$ Depth with trays trays

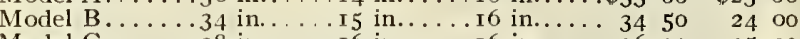

Model C.......38 in..... I6 in..... 6 in.... 36 oo 25 oo

2-Tray Cases.

Model D......30 in..... I 4 in..... I in.... 27002000

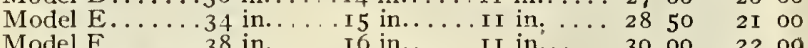

I 6 in...... I in..... 30 oo 22 oo

For Models $A$ and $D, 30$ in. $\ldots \ldots \ldots \ldots \ldots \ldots$

For Models B and E, 34 in.

$\$ 375$

For Models C and F, 38 in.

Flower-Pots. Sizes, height, and width inside

\begin{tabular}{|c|c|c|c|}
\hline & 100 & $I, 000$ & Per \\
\hline & oo & $\$ 850$ & 8-inch \\
\hline$\ldots I$ & 50 & I3 00 & 9-inch:.......... \\
\hline . 2 & 40 & 2000 & Io-inch ............. 30 \\
\hline . 4 & oo & 3600 & I I-inch... \\
\hline$\ldots \ldots 6$ & oo & 5400 & I 2 -inch $\ldots \ldots \ldots \ldots$ \\
\hline$\ldots \ldots$ IO & $5^{\circ}$ & 9000 & I 4-inch \\
\hline
\end{tabular}

Glazing Points, Peerless. No. I for small single-thick glass: 2 , for medium, double-thick glass; No. $2 \mathrm{I} / 2$, for large, double-thick and skylight glass. I,000, $60 \mathrm{cts}$.

Glazing Points, Siebert's. Made of zinc and will not rust. Two sizes, 5/8 and $7 / 8$ inch long. 50 cts. per $1 \mathrm{~b}$.

Grape Protecting Bags. They protect fruit from insects, rust, etc.

No. 2. Small

No. 3. Medium

\$o $75 \quad \$ 600$

Horse Boots. The best make. For size, measure the outer edge of shoe. Per set of 4 boots, \$13.

Melon Nets. Imported. \$I.50 per doz., \$I 2 per Ioo.

Mole Traps, Olmstead's Improved. \$I.75 each.

The Reddick. Powerful spring; easily set. \$I each.

Sprinklers, Scollay, Straight-neck. Large, \$I.25; small, 60 cts.

Angle-neck. \$I.25

Summer Cloud. A greenhouse shading, applied like whitewash. $1 / 2-1 b$. pkt. 50 cts.

Syringe, Reed's Patent. Extra-heavy brass Syringe. $20 \times 13 / 4$ inches. English-made. Two roses and one jet, with quick-filling valves. $\$ 7.50$ each

Tubs, Boddington's Cedar Plant-(With feet, \$I.50 extra).

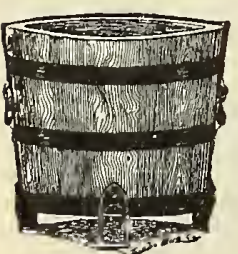

Plant-Tub
Outside top diam. Outside height Price

No. 3. $24 \mathrm{in}$

No. $4.22 \mathrm{in}$

No. 5. 20 in

No. 6. $\quad$ I $81 / 2$ in.

No. $7 . \quad$ I 7 in

No. 9.

No. Io.

No. II.

No. I2.

I 6 in.

I 4 in.

I 2 in.
No. I. 28 in.
22 in...

20 in..

I $81 / 2$ in.

I7 in.

I 5 in. .

I 4 in. .

I 3 in..

12 in....

$91 / 2$ in.

9 in..

7 in..
$\$ 600$

$\begin{array}{ll}5 & 50 \\ 4 & 75\end{array}$

4 oo

350

300

250

200

$\begin{array}{ll}\text { I } & 75 \\ \text { I } & 50\end{array}$

I 25

I 00

\section{THERMOMETERS}

Japanned. Tin case, IO- and I 2 -in., 65 cts., and 80 cts. each.

Self-registering (Maximum and Minimum). $\$ 3.75$ each.

Mushroom-bed. Galvanized frame, wood handles and mercury bath, so constructed as to insure accurate temperature reading instantly. $\$ 2$ each.

Hicks' English Self-registering, Japanned. Tin case, white porcelain indicator, highly finished. The most accurate Thermometer manufactured. 8-inch, $\$ 8.50 ;$ Io-inch, \$0.50; I 2-inch, \$12

\section{FERTILIZERS, MANURES, ETC.}

ASHES, CANADA HARDWOOD. Apply one to two tons to the acre, as one heavy application will help much more than the same quantity would applied in fractions. Bbl. of about 200 lbs., $\$ 3.75$; ton of 2,000 lbs. in bbls., $\$ 30$; by car, $\$ 27$ per ton.

Bone Dust for Quick Action. Effective as a topdressing and for mixing in soil. Ioo lbs. $\$ 3.25$, I66-lb. bag $\$ 4.75$, ton $\$ 50$.

Bone Meal for General Use. Pure ground bone, not quite so finely ground as the preceding. Ioo lbs. $\$ 3,200$ lbs. $\$ 5.50$, ton $\$ 52.50$.

Bone Meal for Roses. For use under glass; the highest quality obtainable. Ioo lbs. $\$ 3.25,200$ lbs. $\$ 6$, ton $\$ 55$.

Bone, Crushed, Coarse. For vine borders, etc. $1 / 4$ inch to $1 / 2$ inch. Ioo lbs. $\$ 3.50$, ton $\$ 60$.

Guano, Peruvian. (Genuine.) High in ammonia, potash and phosphoric acid. Lb. $30 \mathrm{cts}$., 5 lbs. \$I, Io lbs. $\$$ I.50, 25 lbs. $\$ 3,50$ lbs. $\$ 4.50$, I $00 \mathrm{lbs}$. $\$ 7.5$ o.

Guano, Ichthemic. A celebrated English fertilizer. An ideal plant food. 28 lbs. $\$ 2.50,56$ lbs. $\$ 4.50$ I I 2 lbs. $\$ 8$.

NITRATE OF SODA. Ioo to 300 lbs. per acre. 25-lb. bag $\$ 2.50$, $50-1$ b. bag $\$ 4.50$, IOo-lb. bag $\$ 8.50$.

SHEEP MANURE, PULVERIZED. For top-dressing grass, use one or two tons to the acre. Prepared for use by a patent process which destroys all weed seeds, and at the same time preserves the fertilizing properties indefinitely. In bags of Ioo $1 \mathrm{bs} . \$ 2.75,5001 \mathrm{bs}$. $\$ \mathrm{I}_{2}, \mathrm{I}, 000 \mathrm{lbs}$. $\$ 2 \mathrm{I}$, ton $\$ 40$.

Scotch Soot. (Genuine Imported.) Gardeners know the value of the genuine article for stimulating a healthy growth of dark green foliage, and its beneficial effect in freeing the soil from slugs, grubs, and cutworms. Sold in roo-lb. bags only, $\$ 5$ per bag.

Thomson's "Special" Chrysanthemum Manure. An excellent stimulating manure for top-dressing of chrysanthemums and similar plants. 28-1b. bag \$4, 56-lb. bag \$7, I I 2-lb. bag \$13.50.

Thomson's Vine, Plant and Vegetable Manure. So compounded as to combine stimulating with lasting effects. A safe and reliable food and stimulant for every fruit-bearing plant, for foliage and flowering plants, for vegetables and outdoor plants of every description; admirably adapted for mixing with the soil when potting in the proportion of four pounds to each wheelbarrow-load of soil. $28-1 \mathrm{~b}$. bag $\$ 2$, 56-lb. bag $\$ 4$, I I 2-lb. bag $\$ 7.50$.

\section{COLDWELL'S IMPERIAL MOWER}

\section{0-INCH-HIGH WHEEL}

Size

I 4-inch. .

I6-inch.

I 8 -inch.

2o-inch.

\section{COLDWELL'S IMPROVED EXCELSIOR ROLLER MOWER}

Especially adapted for cutting grass borders and putting-greens. Size
I 2 -inch....... \$I 4 oO I 4 -inch....... I5 50 I6 $50 \quad 20$-inch........ 21 $50 \quad 2250$ I6-inch....... I 7 50 I 850

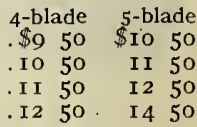

